\title{
The Results of a Laboratory Feasibility Study for the Biological Treatment of Umatilla Groundwater
}

Victor F. Medina, Heather Knotek-Smith, David Gent, January 2012 and Agnes Morrow 


\section{The Results of a Laboratory Feasibility Study for the Biological Treatment of Umatilla Groundwater}

Victor F. Medina, Heather Knotek-Smith, David Gent, and Agnes Morrow

U.S. Army Engineer Research and Development Center

Environmental Laboratory

3909 Halls Ferry Road

Vicksburg, MS 39180-6199

Final report

Approved for public release; distribution is unlimited.

Prepared for U.S. Army Corps of Engineers

Washington, DC 20314-1000

Under Work Unit 33143 
Abstract: The Umatilla Chemical Depot (UMCD) has been slated to close as an Army facility under the Base Realignment and Closure (BRAC) Program. One remaining environmental issue is a groundwater plume contaminated with explosives; the two most critical are 2,4,6-trinitrotoluene (TNT) and 1,3,5-trinitrohexahydro-1,3,5-triazine (RDX). Since 1994, a groundwater pump and treat system has operated at the site as a corrective measure for the contaminated groundwater. The effectiveness of this treatment system has plateaued, and it appears that the system will not meet the long-term treatment goals for the site. This study was conducted to evaluate the potential of bioremediation as a means of optimizing the performance of the groundwater treatment system. Groundwater from the site was collected through the groundwater pump and treat. Soil was collected from the wash out lagoon area, which is the primary source area for most of the contamination. These were used to set up microcosm studies to evaluate the biodegradation of the contaminants. Microcosms were set up using 1-liter Erlenmeyer flasks. The groundwater was spiked to about 1.2 and $0.8 \mathrm{mg} / \mathrm{L}$ of TNT and RDX, respectively. The flask had $200 \mathrm{~g}$ of Umatilla soil (some experiments had $50 \mathrm{~g}$ ) and $500 \mathrm{~mL}$ of spiked groundwater. Various treatments were assessed; i.e., various organic amendments were used as co-substrates to stimulate the degradation of TNT and RDX. Nine amendments, as well as various unamended samples, were tested. The reactors were incubated over a 27- day period under an anaerobic hood. Removal of the contaminants was measured, as was the formation and removal of transformation products, changes in $\mathrm{pH}$, Total Organic Carbon, Eh, and dissolved oxygen. TNT was relatively easy to degrade as it removed even many of the controls. Presumably the anaerobic conditions under the hood were enough to stimulate degradation. RDX, on the other hand, was more difficult to treat. The best amendments were molasses, corn syrup, emulsified oil (EOS), lactose, and whey.

DISCLAIMER: The contents of this report are not to be used for advertising, publication, or promotional purposes. Citation of trade names does not constitute an official endorsement or approval of the use of such commercial products. All product names and trademarks cited are the property of their respective owners. The findings of this report are not to be construed as an official Department of the Army position unless so designated by other authorized documents. 


\section{Contents}

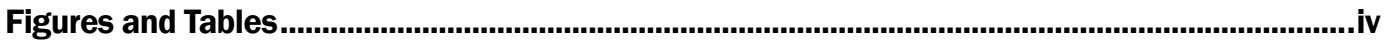

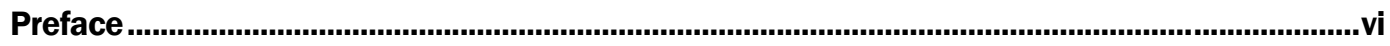

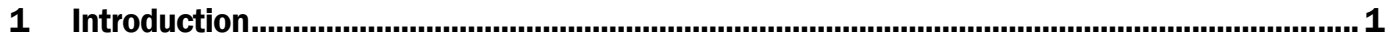

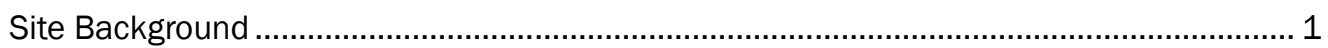

Literature Review - Biodegradation of Explosives in Groundwater..................................... 1

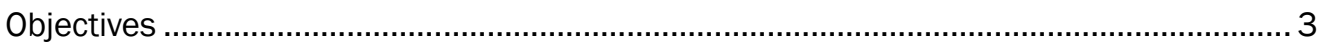

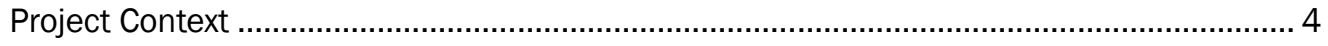

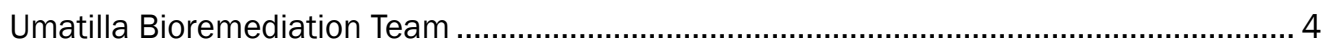

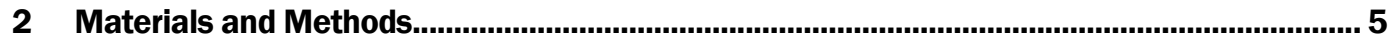

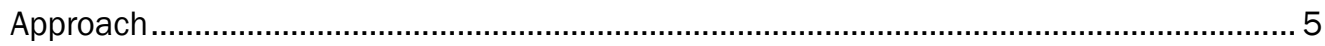

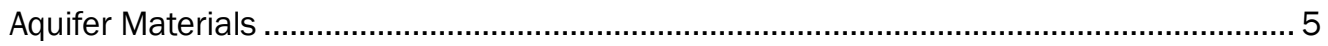

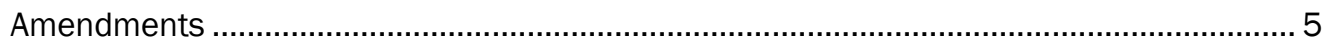

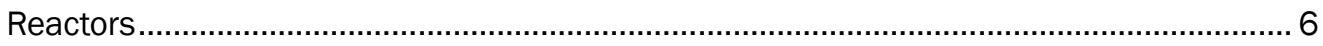

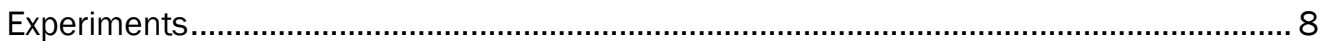

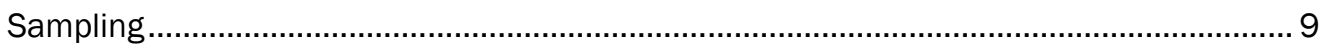

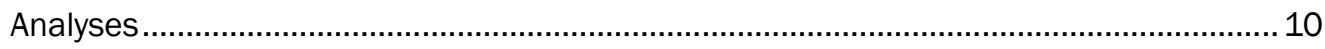

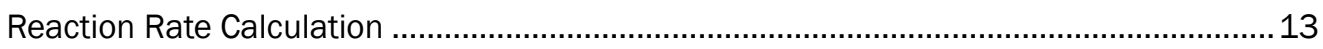

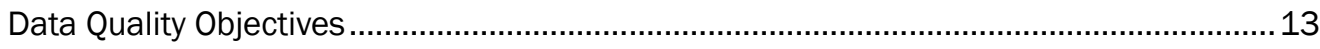

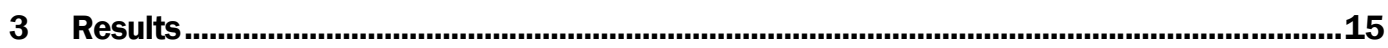

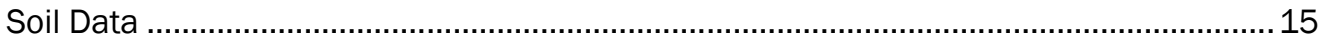

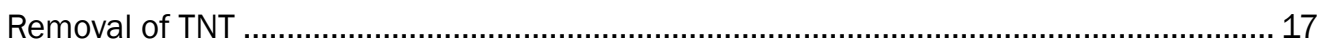

Removal of RDX 20

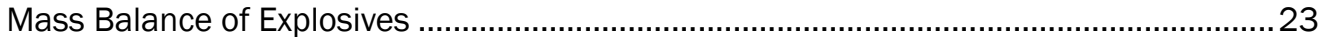

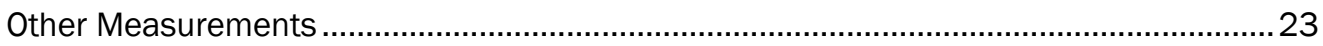

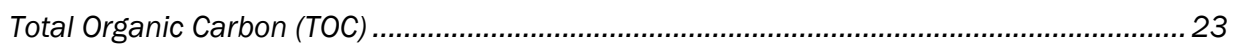

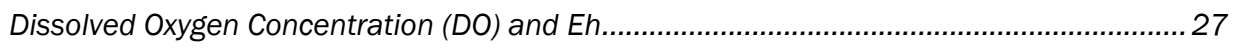

$\mathrm{pH}$

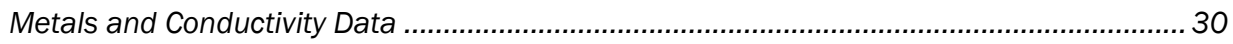

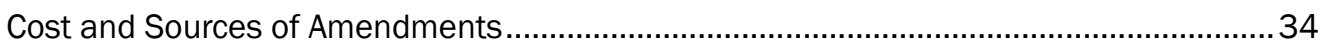

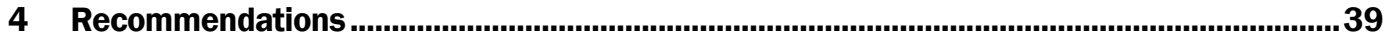

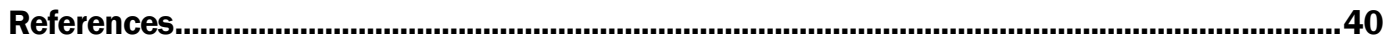

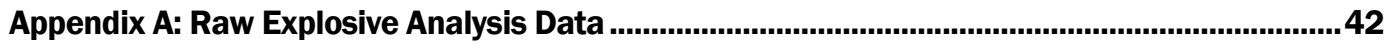

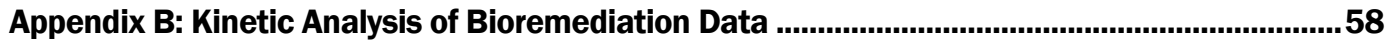

Report Documentation Page 


\section{Figures and Tables}

\section{Figures}

Figure 1. Location in former lagoon area where soil were collected.

Figure 2. Mock up of bioreactor used in this study, an Erlenmeyer flask filled with soil and groundwater, spiked with contaminants and amendments.

Figure 3. Glove box set-up of experimental Run 1.

Figure 4. Close-up of reactors in experimental Run 1.

Figure 5. Temperature controlled sonicator used for extraction of explosives from aquifer sand/soil \& a high pressure liquid chromatograph for explosives analysis.

Figure 6. TOC instrument used during project. It is useful for quantifying organic material in sand/soil and for analyzing additives in groundwater.

Figure 7. Ion chromatograph available for nutrient analysis.

Figure 8. Microwave digestor and ICPOES for analysis of metals................................................... 13

Figure 9. Sieve plots of soils collected from UMCD for use in these studies................................... 16

Figure 10. Run 1 TNT and breakdown products by amendment. ..................................................... 17

Figure 11. Run 2 TNT and breakdown products by amendment. ...................................................... 18

Figure 12. Run 1 RDX and breakdown products by amendment................................................... 21

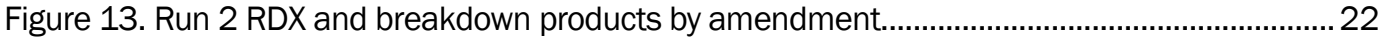

Figure B1. Plot of first-order function linearization TNT Run 1 1........................................................6 60

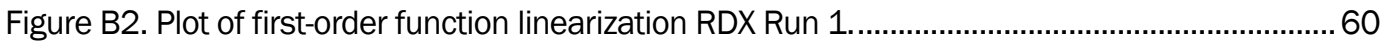

Figure B3. Plot of first-order function linearization TNT Run 2. ..................................................... 62

Figure B4. Plot of first-order function linearization RDX Run 2 …................................................ 62

\section{Tables}

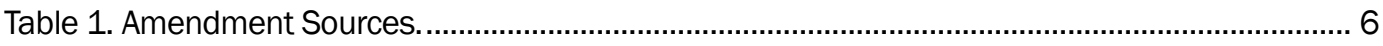

Table 2. Quantities of amendments used in experiments. ............................................................ 9

Table 3. Sample analytes, analysis method, and required volumes................................................. 10

Table 4. Sampling schedule and required volumes for analysis $(\mathrm{mL})$.......................................... 10

Table 5. Data quality objectives for the project. ............................................................................. 14

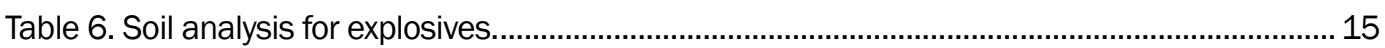

Table 7. Carbon sources sorted on TNT reaction rate................................................................. 19

Table 8. Carbon sources sorted on RDX reaction rate.................................................................. 23

Table 9. Mass balance summary for TNT....................................................................................... 24

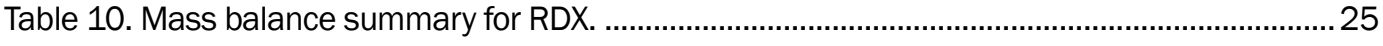

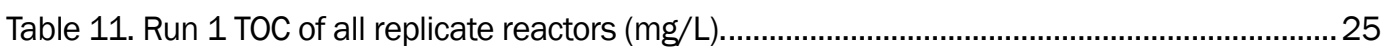

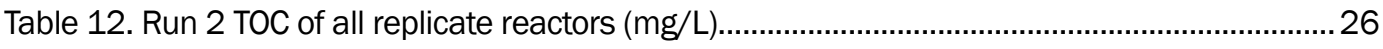

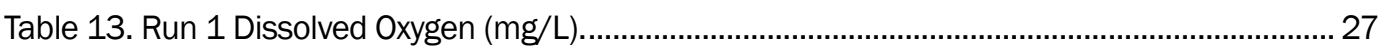




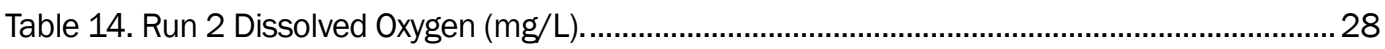

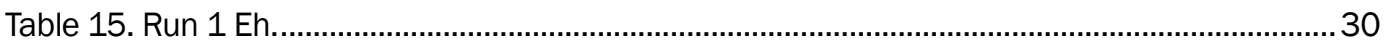

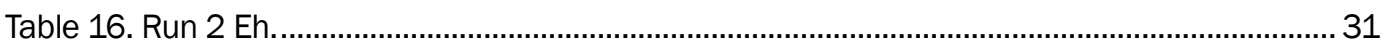

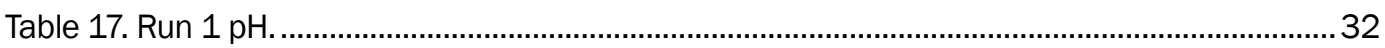

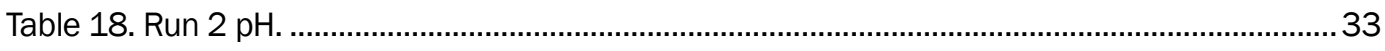

Table 19. Run 1 Metals Analysis. Detection limit was $0.5 \mu \mathrm{g} / \mathrm{L}$. BD means below detection............... 34

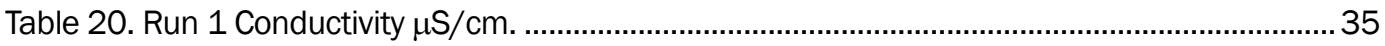

Table 21. Run 2 Metals Analysis. Detection limit was $0.5 \mu \mathrm{g} / \mathrm{L}$. BD means below detection...............36

Table 22. Run 2 Conductivity $\mu \mathrm{S} / \mathrm{cm}$................................................................................... 37

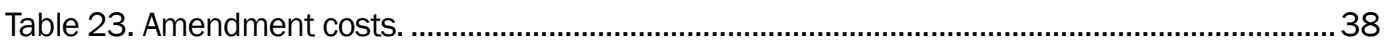

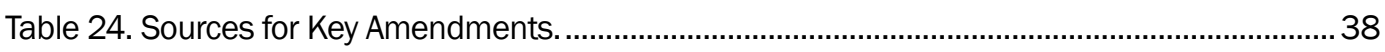

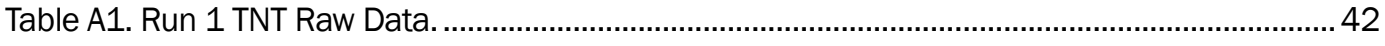

Table A2. Run 14 Amino 2,6-dinitroltoluene Raw Data. .................................................................. 43

Table A3. Run 12 Amino 4,6 dinitrotoluene Raw Data................................................................ 44

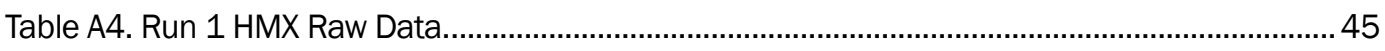

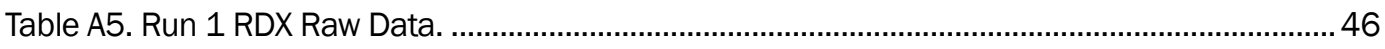

Table A6. Run 1 MNX Raw Data.............................................................................................. 47

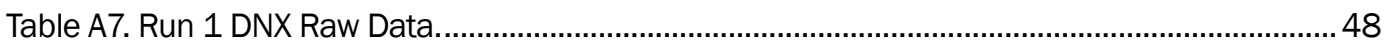

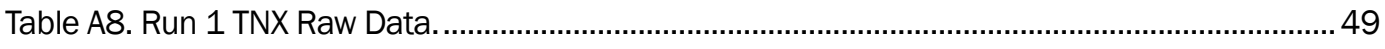

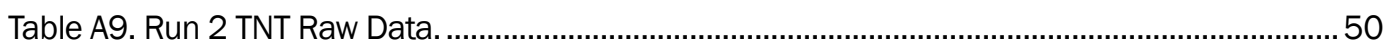

Table A10. Run 24 Amino 2,6-dinitroltoluene Raw Data.................................................................. 51

Table A11. Run 22 Amino 4,6 dinitrotoluene Raw Data..................................................................52

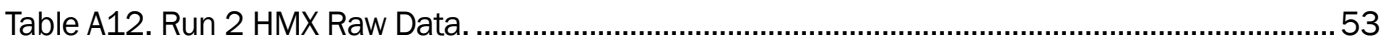

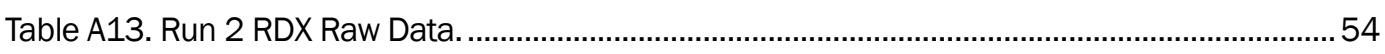

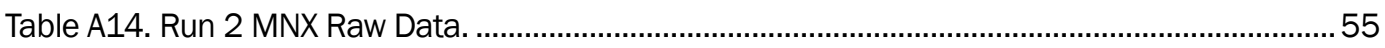

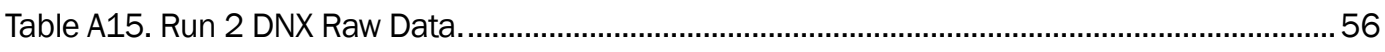

Table A16. Run 2 TNX Raw Data............................................................................................ 57

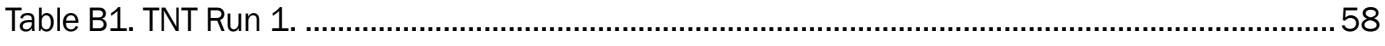

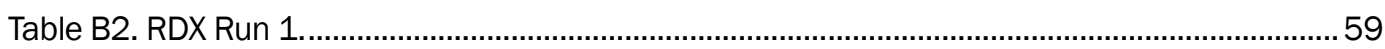

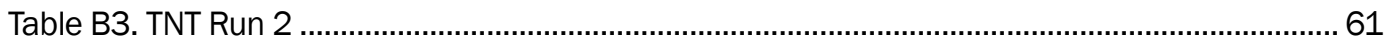

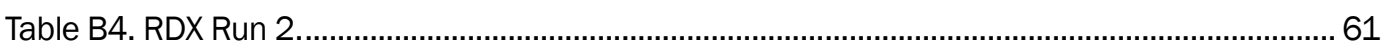




\section{Preface}

This report describes experimental work conducted under funding provided by the Army Corps of Engineers, Seattle District, via a Military Interdepartment Purchase Request (MIPR). The Seattle District received funding for the project through the Base Realignment and Closure (BRAC) Program. Richard Wilson of the Seattle District monitored the progress of the project. The purpose of the project was to investigate biological treatment as a means for optimizing the treatment of explosives-contaminated groundwater at the Umatilla Chemical Depot (UMCD). This research effort was directed by Dr. David Gent under the oversight Dr. Victor F. Medina, P.E., Team Leader of the Environmental Security Engineering Branch.

Dr. Heather Knotek-Smith, directed the laboratory experiments. Agnes Morrow provided laboratory support.

This report was prepared by Dr. Victor Medina, Dr. Heather Knotek-Smith, Dr. David Gent, P.E., and Agnes Morrow, all of Environmental Engineering Branch, Environmental Processes and Engineering Division (EPED), Environmental Laboratory (EL). Dr. Fiona Crocker and Dr. Mansour Zakakhani provided in-house review.

This study was conducted under the direct supervision of W. Andy Martin, Chief, Environmental Engineering Branch, and under the general supervision of Warren P. Lorentz, Chief, EPED, and Dr. Elizabeth C. Fleming, Director, EL.

At the time of publication of this report, COL Kevin J. Wilson was Commander of ERDC, and Dr. Jeffery Holland was Director. 


\section{Introduction}

\section{Site Background}

The Umatilla Chemical Depot (UMCD) is located in Hermiston, Oregon, and served as a depot facility for explosive and chemical munitions from 1941 to 1990. In 1990, the UMCD was placed on the Base Realignment and Closure (BRAC) list as a facility to be closed. To prepare the facility for transition to unrestricted civilian use, the site must be restored from an environmental standpoint. Over the past 20 years, the non-chemical munitions at UMCD have been transferred to another facility or decommissioned. An incineration plant has been set up for the destruction of chemical munitions and much of the inventory has been treated. In addition, environmental issues at the facility have been addressed.

One remaining environmental issue is a groundwater plume contaminated with the explosives: 2,4,6-trinitrotoluene (TNT) and 1,3,5-trinitrohexahydro-1,3,5-triazine (RDX). In 1994, a groundwater pump and treat facility was installed at the site. Groundwater is extracted through three pumping wells (four were installed, but only three operate) and the explosives are removed using granular-activated carbon (U.S. Army Corps of Engineers, 2010). Over the past five years, treatment has stalled. This project was an investigation to explore the use of bioremediation as a means of optimizing.

The results of this project were used to design field studies that were planned to investigate the effectiveness of biotreatment for Umatilla groundwater, including a push-pull study and a study investigating the efficacy of using surface infiltration as a means to deliver amendments, called the Lagoon Amendment Pilot Project (LAPP).

\section{Literature Review - Biodegradation of Explosives in Groundwater}

There have been numerous studies based on bioremediation of high explosives in water. These studies often involve the addition of a cosubstrate - a readily biodegradable material that stimulates microbial growth and consumes oxygen and other electron acceptors, causing conditions to become more reducing. Nitrated compounds can often be 
degraded in anaerobic environments created by adding an organic cosubtrate (Crawford, 2002).

Hoferkamp and Weber (2006) studied the kinetics of nitroaromatic reduction as a function of terminal electron acceptor in natural sediments. They found that lactate could serve as a source of organic carbon in sulfate, reducing sediment slurries. They also found that the reaction rates were significantly lower when the same slurries were amended with acetate. They concluded that the electron source and the system parameters, such as $\mathrm{pH}$, play a determinant role in the reaction kinetics.

Krumholz et al. (1997) studied the transformations of TNT in groundwater aquifer slurries under methanogenic, sulfate-reducing and nitrate-reducing conditions. The groundwater used in these studies was collected from a methanogenic aquifer and was supplemented with the desired nitroaromatic compound to a final concentration of $100 \mu \mathrm{M}$ or $22.8 \mathrm{ppm}$ in the case of TNT. The study found that the TNT was depleted three to five times faster under methanogenic conditions than it was under the sulfate and nitratereducing conditions. Anaerobic biodegradation of explosives by a methanogenic mixed culture was further investigated by Adrian et al. (2003). This work amended a basal medium containing $11.4 \mathrm{ppm}$ TNT and 5.5 ppm RDX with ethanol, propylene glycol, butyrate or hydrogen gas as the electron donor. They found that all of the TNT and RDX were completely transformed in all of the bottles and concluded that "the addition of $\mathrm{H}_{2}$ or electron donors that produced $\mathrm{H}_{2}$ may be a useful strategy for enhancing the anaerobic biodegradation of explosives in contaminated ground water and soils." Adrian and Arnett (2007) tested this conclusion on groundwater and contaminated soil (2.4 ppm RDX and 3.8 ppm TNT) using anoxic microcosms constructed from the contaminated environment amended with ethanol and propylene glycol. They found that the amendments enhanced the biotransformation of RDX in the explosive-contaminated soil but that the TNT was most likely chemically transformed.

Schaefer et al. (2007) studied the biodegradation of RDX (5 $\left.\mathrm{mg} \mathrm{L}^{-1}\right)$ and $\operatorname{HMX}\left(1 \mathrm{mg} \mathrm{L}^{-1}\right)$ when co-mingled with nitrate $\left(4 \mathrm{mg} \mathrm{L}^{-1}\right)$ and perchlorate (5 $\left.\mathrm{mg} \mathrm{L}^{-1}\right)$. They utilized an emulsified vegetable oil as a substrate and found that it effectively promoted the biological reduction of nitrate, RDX, and perchlorate in the microcosm experiments and all four target contaminants in the column flow-through studies. 
A soil slurry reactor was used by Boopathy et al. (1998) to study the bioremediation of a TNT-contaminated soil using molasses as a cosubstrate. The TNT concentration in the soil ranged from 4,000 to $12,000 \mathrm{mg} \mathrm{kg}^{-1}$ and the molasses solution was $0.3 \%$. The tests resulted in the transformation of TNT by batch treatment and complete degradation of TNT in the semicontinuous treatments. Boopathy and Manning (1999) continued this work by adding surfactant with the molasses; in this way, they were able to completely transform the TNT. The addition of the surfactant most likely keeps the TNT mineralization products from binding to the slurry and therefore remains bioavailable and can be completely broken down. Additionally, Boopathy and Manning (2000) demonstrated the ability of a $0.3 \%$ molasses solution to serve as a co-substrate for the degradation of RDX. In this experiment, a soil slurry reactor was used to decrease an initial soil concentration of $7000 \mathrm{mg} \mathrm{kg}^{-1} \mathrm{RDX}$ by $98 \%$ in four months.

Waisner et al. (2002) used a tagged RDX compound to maximize the mineralization of the compound within soil-water slurries under anaerobic and aerobic conditions. It was found that the RDX (202 $\left.\mu \mathrm{g} \mathrm{\textrm {L } ^ { - 1 }}\right)$ was completely mineralized when acetate $\left(92 \mathrm{mg} \mathrm{L}^{-1}\right)$ was added to the test reactors. Wani and Davis (2003) also saw the complete removal of RDX $\left(1.8 \mu \mathrm{g} \mathrm{L}^{-1}\right)$ using acetate (500 $\left.\mathrm{mg} \mathrm{L}^{-1}\right)$ as a carbon source. This work studied the degradation in flow-through columns packed with aquifer material.

\section{Objectives}

Based on the studies presented above, it appeared that biodegradation of explosives stimulated by the addition of an organic co-substrate could be an effective approach for treating low levels of explosives concentrations at the Umatilla Army Depot. The objectives of this study were:

- to evaluate various amendments and amendment combinations for their ability to promote biodegradation;

- to assess whether biodegradation can meet treatment goals $\left(2 \mu \mathrm{g} \mathrm{L}^{-1}\right.$ for RDX and TNT);

- to provide recommendations for the best amendments for subsequent field experiments, taking into account cost considerations; and

- to provide kinetic data for affiliated modeling efforts. 


\section{Project Context}

This project will provide data for two other related field projects. When combined, these data will provide information to evaluate the efficacy of bioremediation to meet treatment goals at Umatilla. Further, these combined projects will provide the basis for the design of full-scale applications. The two additional projects include a push-pull test, which is conducted in situ, allowing for dispersion effects to be evaluated. The other project will deliver amendments into the aquifer via an infiltration gallery.

\section{Umatilla Bioremediation Team}

A team was assembled to assess the feasibility of applying bioremediation as a means of optimizing the Umatilla Groundwater treatment system. The Seattle District coordinated the overall effort, was the primary liaison with the various regulatory agencies, and was in charge of the push-pull testing. The U.S. Army Engineer Research and Development Center (ERDC) Environmental Laboratory (EL) provided laboratory experimentation and coordinated any analytical work associated with field endeavors. The Army Environmental Command designed an infiltration study which will be implemented by the Seattle District. The ERDC Coastal and Hydrology Laboratory (CHL) provided modeling support for the team. The Environmental Protection Agency (EPA) and the Oregon Department of Environmental Quality (ODEQ) provided oversight throughout the project. 


\section{Materials and Methods}

\section{Approach}

This study used batch reactors to study the degradation of explosives stimulated by adding organic co-substrates. Reactors that allowed for multiple sampling were designed, constructed and used. Reactor preparation, incubation, and sampling were conducted under an anaerobic hood. The goal of this project was to evaluate in a controlled laboratory setting potential amendments that could be added to explosivescontaminated groundwater at the Umatilla Army Depot to simulate biodegradation of these contaminants.

\section{Aquifer Materials}

Groundwater for the experiments was collected on-site from the influent spigot of the groundwater treatment system by the Seattle District. The reactors were spiked to have an RDX concentration of 800 and a TNT concentration of $1200 \mu \mathrm{g} \mathrm{L}^{-1}$. Spiking allowed the experiments to be conducted more quickly since the analytical approach will not require any concentration steps. Spiking also allowed us to study the formation and degradation of breakdown products.

Time and cost constraints did not allow for the collection of actual aquifer material from the site. Instead, ERDC personnel collected soil material from the drainage lagoon site as a surrogate for actual groundwater material. Three buckets of soil from this area were collected (Figure 1). Approximately one foot of soil was removed from the three locations prior to the sample collection to minimize the amount of vegetative material. The soil had the appearance of basalt rocks of various sizes with sand.

\section{Amendments}

Nine amendments were tested in this study. They were chosen based on previous results for the treatment of explosives described in the literature. The general sources of amendments used in this study are listed in Table 1. 


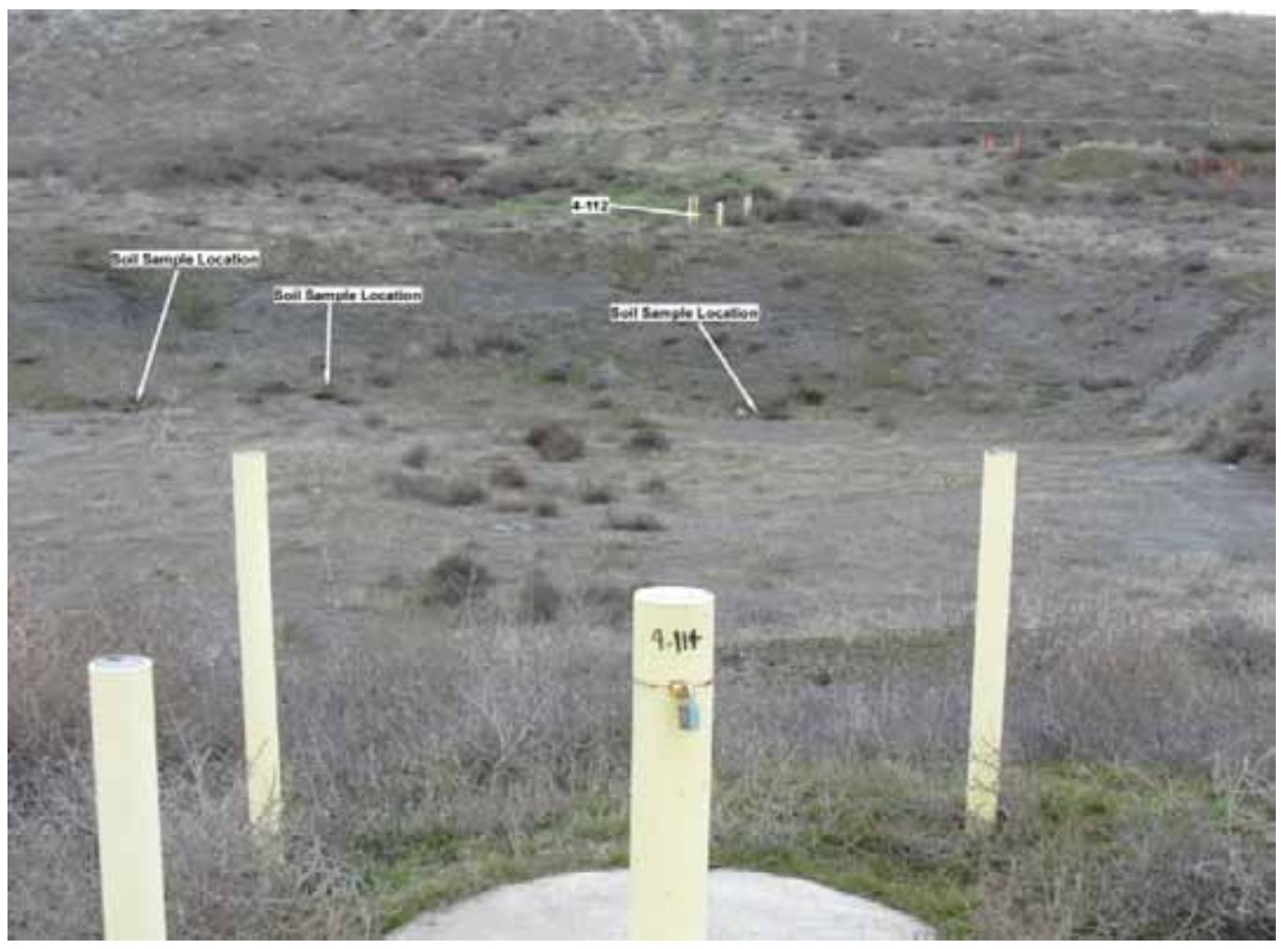

Figure 1. Location in former lagoon area where soil were collected.

Table 1. Amendment Sources.

\begin{tabular}{|l|l|}
\hline molasses & Grandma's Molasses \\
\hline high fructose corn syrup & Kroger brand \\
\hline lactose & Columbia River Processors, Boardman, OR \\
\hline cheese whey & Columbia River Processors, Boardman, OR \\
\hline lactate & JWR Bioremediation \\
\hline ethanol & Everclear (95\%) \\
\hline emulsified soybean oil & EOS Remediation \\
\hline benzoic acid & technical grade \\
\hline sodium acetate & technical grade \\
\hline
\end{tabular}

\section{Reactors}

A mock-up using a 1-liter Erlenmeyer flask was used to test an appropriate mixture of soil and water (Figure 2). Based on this mock-up, the bench scale treatability study was conducted in prepared reactors using 1 liter amber screwtop bottles with $200 \mathrm{~g}$ of aquifer material (some reactors in test 2 used $50 \mathrm{~g}$ and are labeled as $50 \mathrm{~g}$ reactors) and $500 \mathrm{~mL}$ of amended/spiked groundwater (Figures 3 and 4). All reactors were sealed with a screw top and incubated in an anaerobic glove box on a shaker at room temperature. 


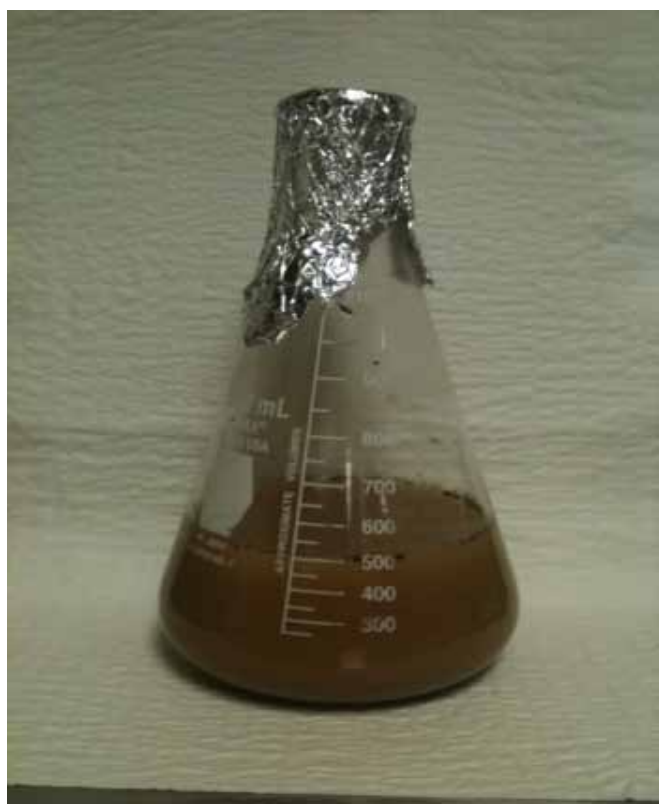

Figure 2. Mock up of bioreactor used in this study, an Erlenmeyer flask filled with soil and groundwater, spiked with contaminants and amendments.

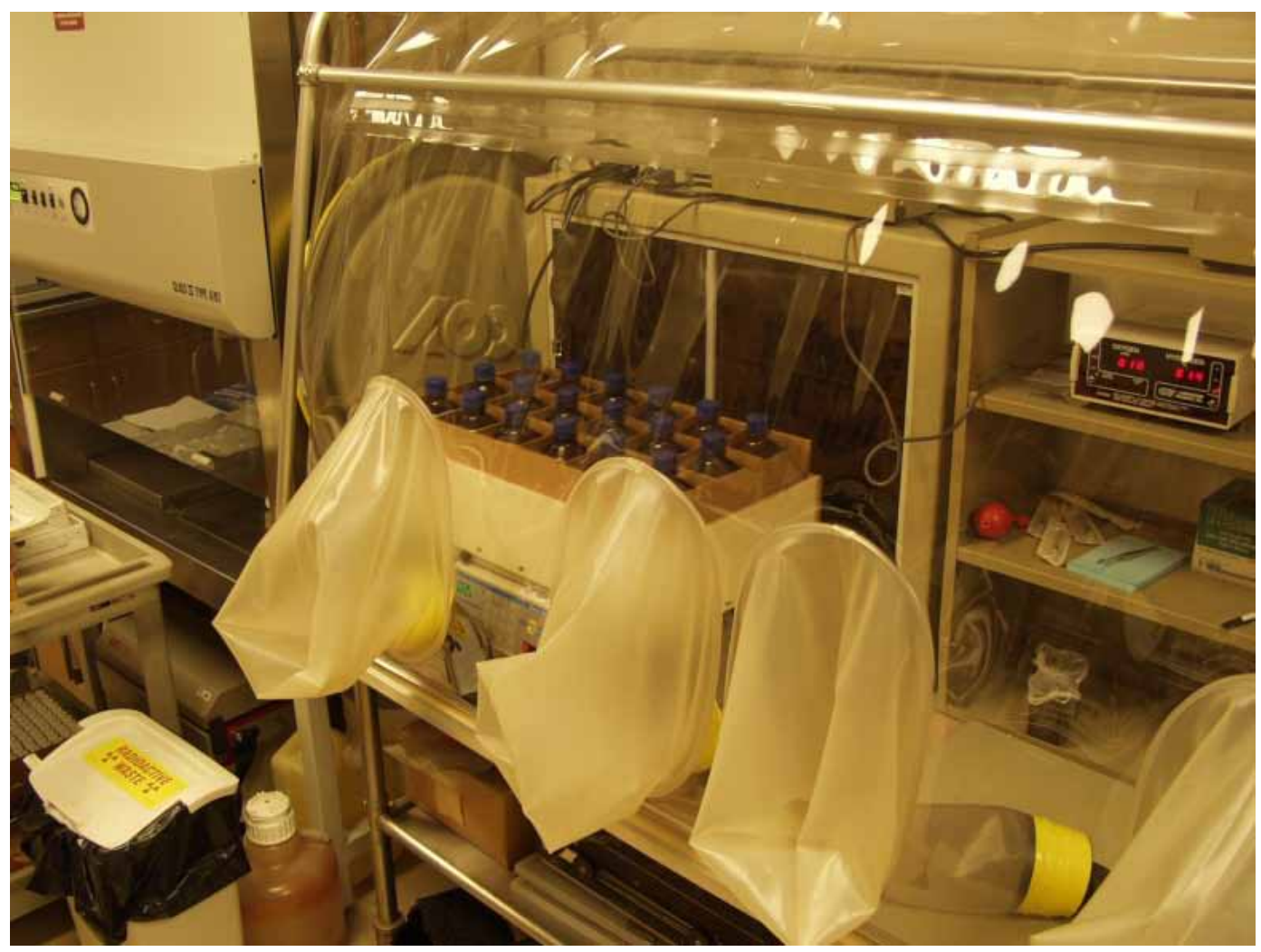

Figure 3. Glove box set-up of experimental Run 1. 


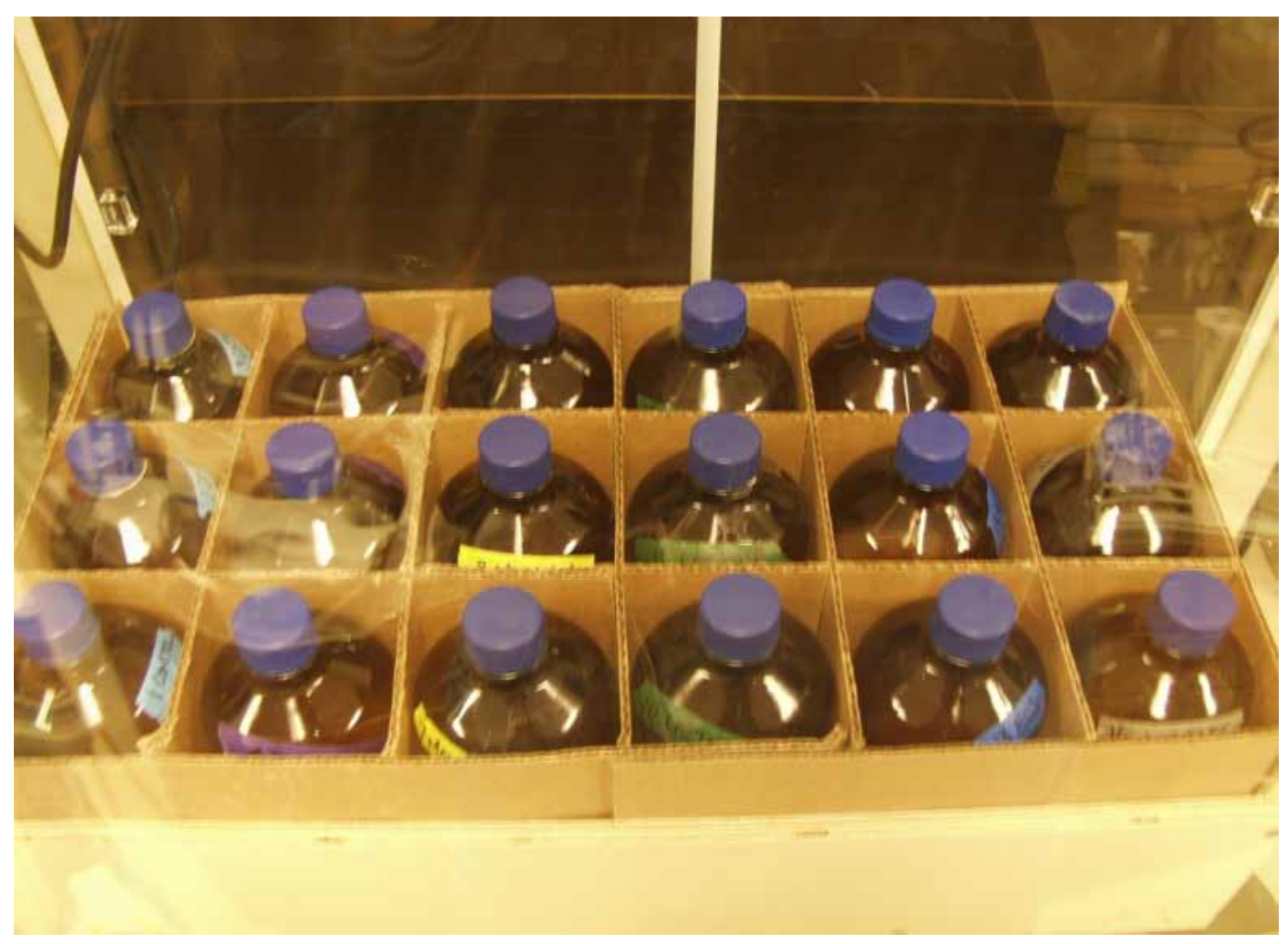

Figure 4. Close-up of reactors in experimental Run 1.

\section{Experiments}

Due to size limitations in the glove box, the work was carried out in two experimental runs. The co-substrates (which were chosen based on studies documented in the literature or after personal communication with experts) tested in Run 1 were:

- high-fructose corn sugar (based on promising results obtained using soft drink by-products described by Ira May)

- molasses (Boopathy et al. 1998)

- lactose (the remaining filtrate of cheese whey - see below)

- emulsified oil (EOS) (Schaefer et al. 2007)

- acetate (Waisner et al. 2002 and Wani and Davis, 2003) and

- a control consisting of unamended well water and sediment, but not autoclaved.

Experimental Run 2 tested the following treatments:

- Sodium Lactate (Hoferkamp and Weber 2006)

- Liquid cheese whey (promising results were reported by Shaw Environmental, Hatzinger, Pers. Comm.) 
- Benzoic acid chosen due to promising results for treatment of perchlorate (Stroo and Norris 2008)

- Ethanol (Krumholz et al. 1997)

- A control consisting of unamended well water and sediment, but not autoclaved.

- An autoclaved control (autoclaved twice one day apart and a third time one week later and two times two weeks later one day apart)

- A low solids (50 g/500 mL) control, not autoclaved

- A low solids (50 g/500 mL) treatment with Lactose

Studies by Wani and Davis (2003) indicated that $500 \mathrm{mg} \mathrm{L}^{-1}$ of acetate was effective for complete RDX degradation. We expected levels of other amendments to be near the same level. Table 2 summarizes the quantities of each amendment used in the experiment.

Table 2. Quantities of amendments used in experiments.

\begin{tabular}{|l|l|l|l|l|}
\hline Amendment & Quantity Added & $\mathrm{mol} / \mathrm{L}$ & Initial TOC & Initial St Dev \\
\hline sodium acetate & $2 \mathrm{~g} / \mathrm{L}$ & 0.0244 & 438 & 12 \\
\hline lactate & $6 \mathrm{~mL} / \mathrm{L}$ & 0.0712 & 630 & 14 \\
\hline molasses & $3 \mathrm{~g} / \mathrm{L}$ & 0.0149 & 977 & 256 \\
\hline corn syrup & $4 \mathrm{~g} / \mathrm{L}$ & 0.0167 & 1002 & 300 \\
\hline ethanol & $10 \mathrm{~mL} / \mathrm{L}$ & 0.1629 & 1638 & 173 \\
\hline benzoic acid & $0.1 \mathrm{~g} / \mathrm{L}$ & 0.0008 & 47 & 13 \\
\hline EOS & $10 \mathrm{~mL} / \mathrm{L}$ & 0.0346 & 539 & 87 \\
\hline lactose & $20 \mathrm{~mL} / \mathrm{L}$ & $?$ & 1646 & 181 \\
\hline whey & $6 \mathrm{~mL} / \mathrm{L}$ & $?$ & 211 & 11 \\
\hline
\end{tabular}

\section{Sampling}

For experiment 1, samples were taken at the following intervals: o days, 1 day, 2, 5, 8, 12, 15, 20, and 27 days. This timeframe was sufficient to see degradation as well as to allow evaluation of any lag phase. A lag phase had been found in studies on the sequential biodegradation of TNT and RDX mixtures (Sagi-Ben Moshe et al. 2008) in groundwater.

Table 3 summarizes measurements that were conducted on the liquid samples throughout the experiment. Table 4 summarizes the analytical frequency and sample volumes needed. At the end of the experiment, the aquifer soil was also extracted for explosives. 
Table 3. Sample analytes, analysis method, and required volumes.

\begin{tabular}{|l|l|l|}
\hline Analysis & Method & Volume Needed \\
\hline $\begin{array}{l}\text { RDX, TNT and transformation products } \\
\text { using High Pressure Liquid Chromatography } \\
\text { (Figure 5) }\end{array}$ & & \\
$\begin{array}{l}\text { Other explosives found on the analyte list of } \\
\text { EPA Method 8330b }\end{array}$ & EPA 8330 (USEPA 2006) & $2(2 \mathrm{~mL})=4$ \\
\hline pH & $\begin{array}{l}\text { EPA 150.2 (USEPA } \\
1982 b)\end{array}$ & 0 \\
\hline Oxygen Reduction Potential (ORP) & ASTM D1498-00 & 0 \\
\hline Total Organic Carbon (TOC) (Figure 6) & $\begin{array}{l}\text { EPA 9060A (USEPA } \\
2004)\end{array}$ & $5-10 \mathrm{~mL}$ \\
\hline Nitrate (Figure 7) & EPA 300.0 (USEPA 1993) & $2 \mathrm{~mL}$ \\
\hline $\begin{array}{l}\text { Dissolved Iron and Manganese using } \\
\text { ICPOES (Figure 8) }\end{array}$ & EPA 200.7 (USEPA 1994) & $5 \mathrm{~mL}$ \\
\hline Conductivity & $\begin{array}{l}\text { EPA 120.1 (USEPA } \\
1982 a) ~\end{array}$ & 0 \\
\hline
\end{tabular}

Table 4. Sampling schedule and required volumes for analysis $(\mathrm{mL})$.

\begin{tabular}{|l|l|l|l|l|l|}
\hline Day & $\begin{array}{l}\text { RDX, TNT, } \\
\text { Transformation } \\
\text { Products }\end{array}$ & TOC & Nitrate & Fe Mg & Total Volume \\
\hline 0 & 4 & 5 & 2 & 5 & 16 \\
\hline 1 & 4 & & & & 4 \\
\hline 2 & 4 & & & & 4 \\
\hline 5 & 4 & & & & 4 \\
\hline 8 & 4 & & & & 4 \\
\hline 12 & 4 & 10 & 2 & 5 & 21 \\
\hline 15 & 4 & & & & 4 \\
\hline 20 & 4 & & & & 4 \\
\hline 27 & 4 & 10 & 2 & 5 & 21 \\
\hline
\end{tabular}

Based on the results of experiment 1 , it was determined that the sampling frequency for experiment 2 could be abbreviated somewhat. Sampling was conducted at $0,2,7,15$, and 24 days.

\section{Analyses}

The sand/soil samples were homogenized, then extracted and analyzed for the following: 
- RDX, TNT, and transformation products using extraction and analysis specified in EPA method 8330.

- Other explosives constituents listed in the analyte list of EPA method $8330 b$.

- $\quad$ pH using EPA Method 150.2.

- Total organic carbon (TOC) using EPA Method 415.1.

- Iron, manganese, and calcium using EPA Method 3052 (Microwave Assisted Acid Extraction) for sample digestion and EPA Method 415.1 (Inductively Coupled Plasma with Optical Emission Spectrophotometry (ICPOES) for analysis.

- Grain size and soil characteristics.

In addition, groundwater collected from the site was mixed into a common container, then analyzed for the following:

- RDX, TNT, and transformation products using EPA method 8330, modified to include nitroso products from RDX (High Pressure Liquid Chromatography) (Figure 5)
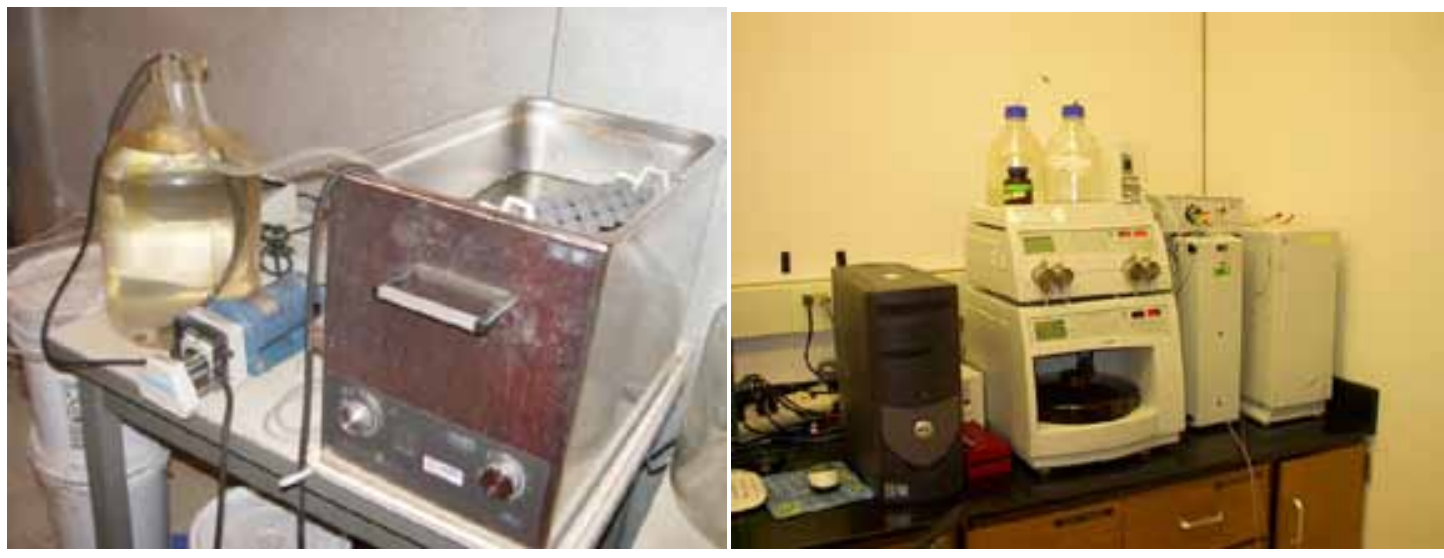

Figure 5. Temperature controlled sonicator used for extraction of explosives from aquifer sand/soil \& a high pressure liquid chromatograph for explosives analysis.

- Other explosives constituents listed in the analyte list of EPA method $8330 b$.

- pH using EPA Method 150.2

- Oxidation Reduction Potential (ORP) using ASTM D1498-oo

- Total organic carbon (TOC) (EPA Method 415.1) or measurement of amendment (Figure 6)

- Nitrate using EPA Method 300.o (Ion Chromatography) (Figure 7)

- Dissolved iron and manganese using EPA Method 200.7 (ICPOES) (Figure 8) 


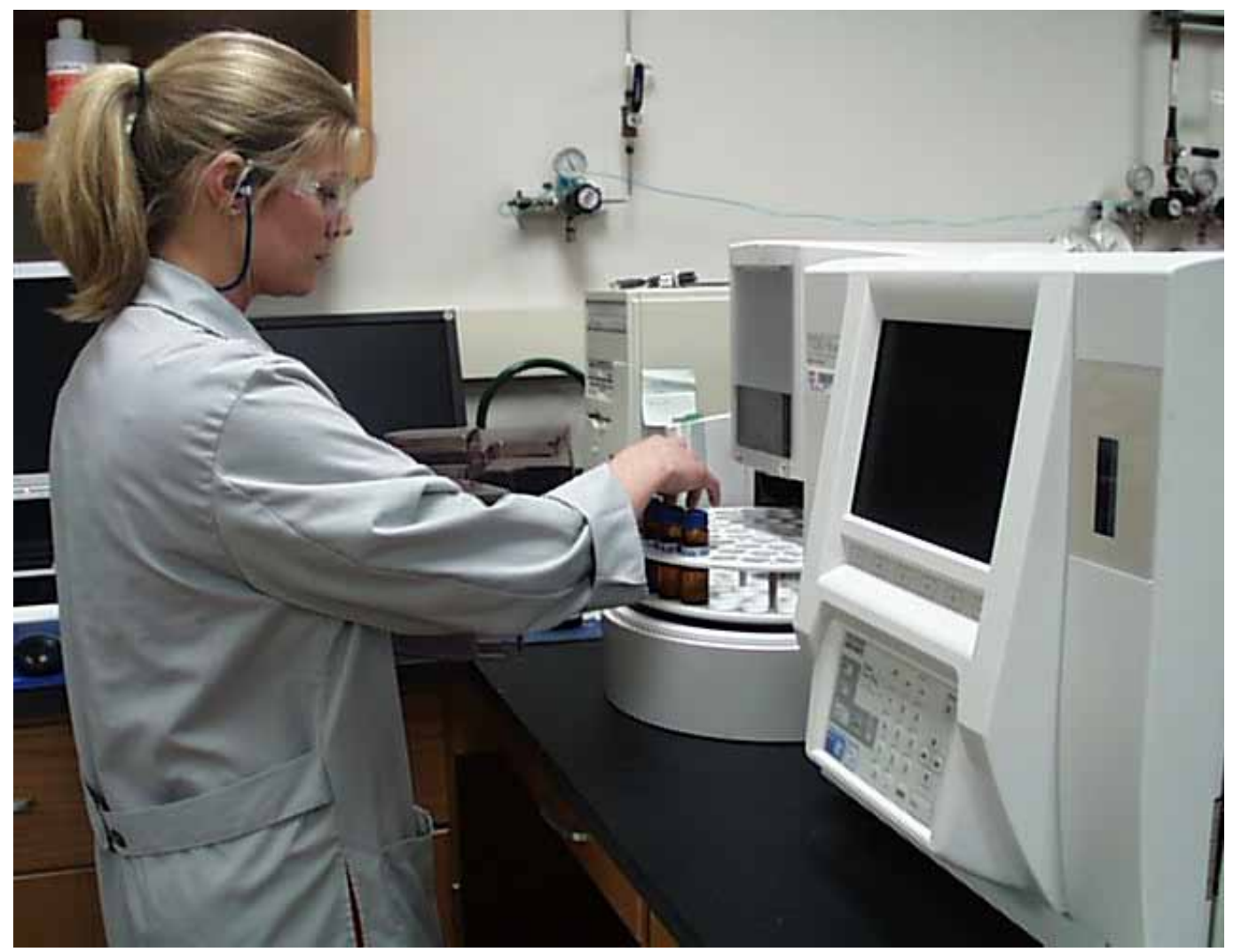

Figure 6. TOC instrument used during project. It is useful for quantifying organic material in sand/soil and for analyzing additives in groundwater.

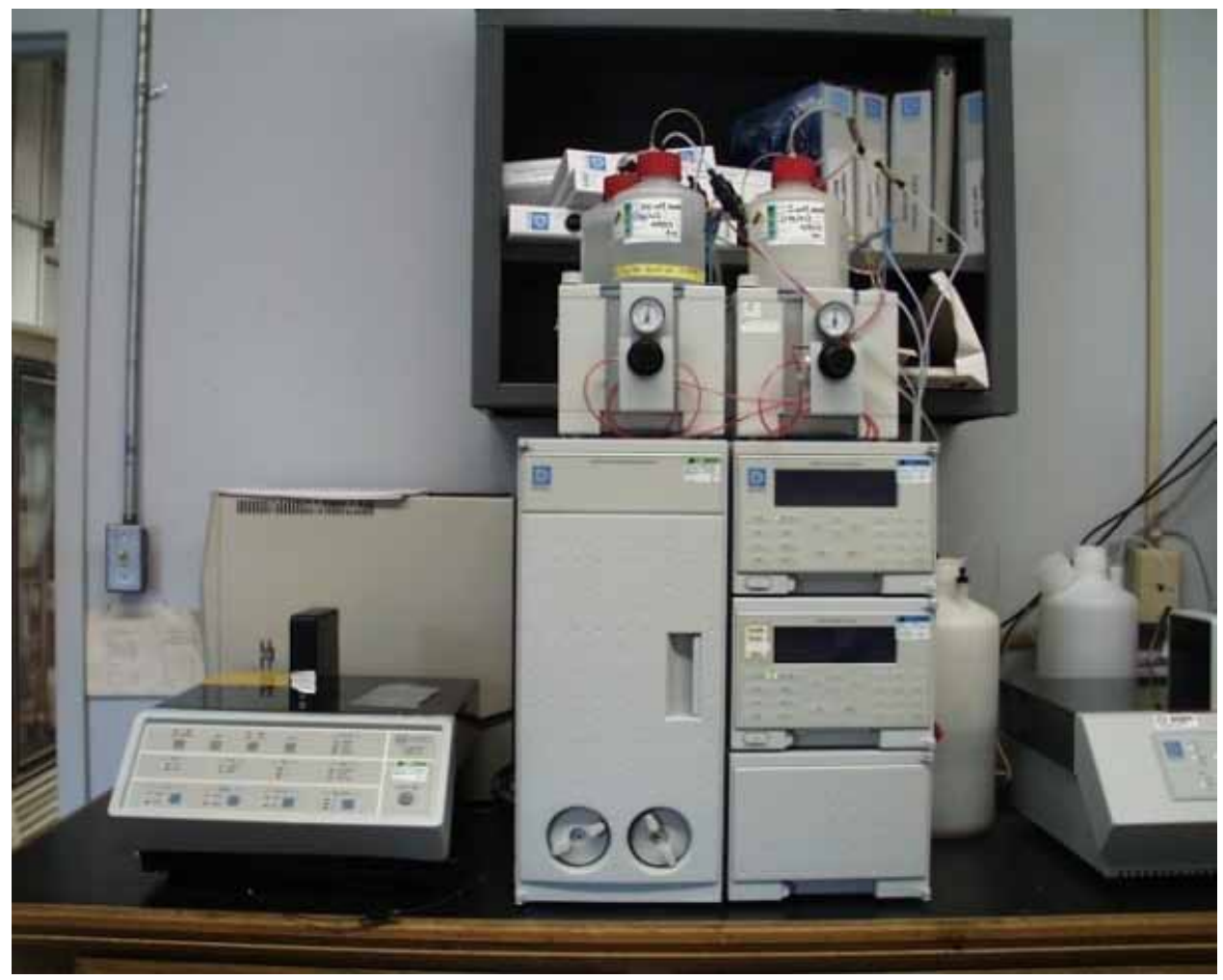

Figure 7. Ion chromatograph available for nutrient analysis. 

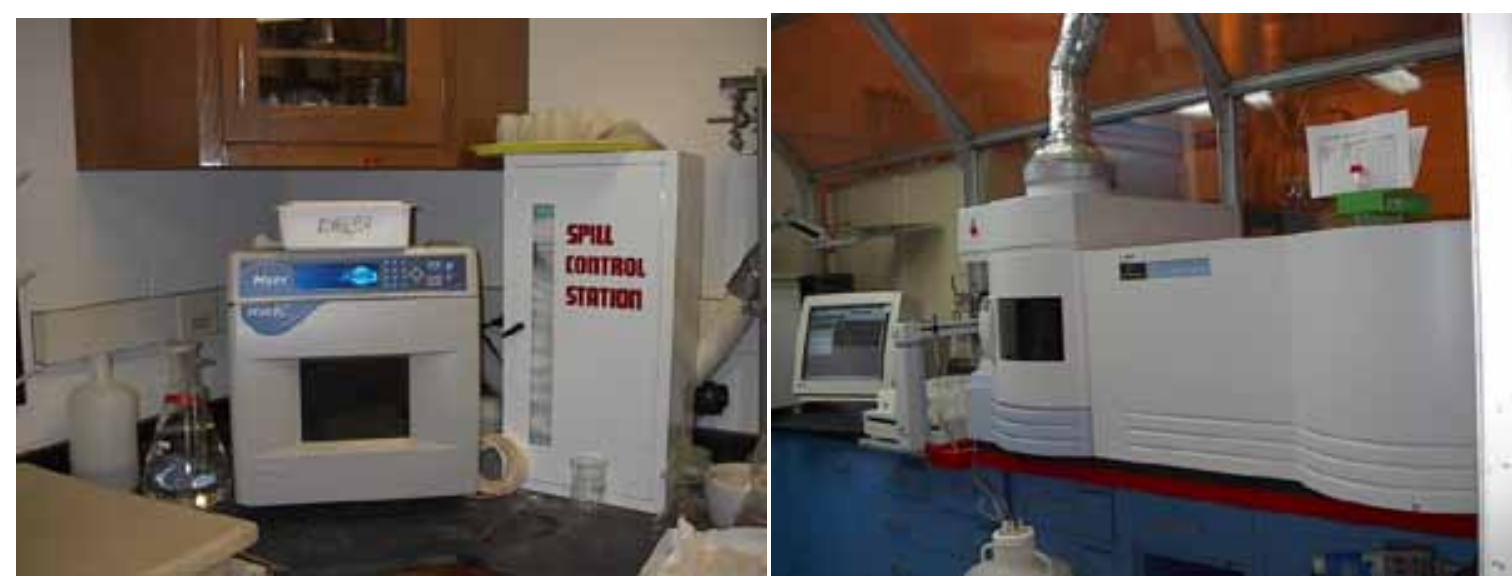

Figure 8. Microwave digestor and ICPOES for analysis of metals.

- Conductivity using EPA Method 120.1

- Suspended solids using EPA method 160.2

The same analyses were conducted on samples collected during the experiment and on the soil afterwards.

\section{Reaction Rate Calculation}

The degradation rate was assumed to be first order (Eweis et al. 1998). Determination of the reaction rate was based on Equation 1. A linearized form of this equation is shown in Equation 2. A plot of this function results in $\mathrm{k}$, the slope of the curve. The half life is defined as the time needed to biodegrade $50 \%$ of the contaminant initially present. The equation used to calculate this value is shown in Equation 3.

$$
\begin{gathered}
C=C_{0} e^{-k t} \\
\ln \frac{C_{0}}{C}=k t \\
t=-\frac{1}{k} \ln \frac{C}{C_{0}}=-\frac{\ln (0.5)}{k}
\end{gathered}
$$

\section{Data Quality Objectives}

Table 5 gives the data quality objectives set by the bioremediation team for the project. The experimental plan met all of the objectives, providing the basis for amendment selection and allowing for the quantification of degradation rates. The experiments also evaluated transformation products. 
Table 5. Data quality objectives for the project.

\begin{tabular}{|c|c|c|c|}
\hline Objective & Data Gap & Method & Data Use/Decision \\
\hline $\begin{array}{l}\text { ERDC Vicksburg } \\
\text { Laboratory Treatability Testing } \\
\text { - Screen multiple amendments } \\
\text { - Determine RDX and TNT } \\
\text { transformation rates } \\
\text { - Identify potential transformation } \\
\text { products }\end{array}$ & $\begin{array}{l}\text { Cost-effective } \\
\text { amendment(s) } \\
\text { Degradation rates } \\
\text { Final extent of } \\
\text { degradation } \\
\text { Transformation } \\
\text { products }\end{array}$ & $\begin{array}{l}\text { Batch tests } \\
\text { Analytes: } \mathrm{RDX}, \mathrm{TNT}, \\
\text { and transformation } \\
\text { intermediates, } \\
\text { dissolved } \mathrm{Fe}, \mathrm{O}_{2}, \mathrm{SO}_{4} \text {, } \\
\text { ORP, } \mathrm{NO}_{3}, \mathrm{TOC} \text { (or } \\
\text { substrate), pH }\end{array}$ & $\begin{array}{l}\text { Identify amendments } \\
\text { for push-pull test } \\
\text { Quantify rate, evaluate } \\
\text { cost }\end{array}$ \\
\hline
\end{tabular}




\section{Results}

\section{Soil Data}

Table 6 summarizes explosives data collected from homogenized samples from the lagoon area at the UMCD. Various explosives and transformation products were detected, including HMX, RDX (although no transformation products were found), TNT, 1,3,5-Trinitrobenene (TNB) and 4-amino-2,6dinitrotoluene (4ADNT). Soils from the three buckets were mixed and homogenized for the actual study. Equal masses from each bucket were placed on a stainless steel tray. The soils were well mixed then sieved though a \#10 $(2 \mathrm{~mm})$ sieve to remove the largest rocks before placement in the reactors. Figure 9 summarizes the grain sieve analysis of the buckets of soil.

Table 6. Soil analysis for explosives.

\begin{tabular}{|l|l|l|l|}
\hline Analyte & $\begin{array}{l}\text { Bucket 1 } \\
\mu \mathrm{g} / \mathrm{kg}\end{array}$ & $\begin{array}{l}\text { Bucket 2 } \\
\mu \mathrm{g} / \mathrm{kg}\end{array}$ & $\begin{array}{l}\text { Bucket 3 } \\
\mu \mathrm{g} / \mathrm{kg}\end{array}$ \\
\hline $\mathrm{HMX}$ & 6610 & 9690 & 3920 \\
\hline TNX & $<19.8$ & $<19.8$ & $<19.9$ \\
\hline DNX & $<19.8$ & $<19.8$ & $<19.9$ \\
\hline MNX & $<19.8$ & $<19.8$ & $<19.9$ \\
\hline RDX & $<19.8$ & 294 & 429 \\
\hline 1,3,5-Trinitrobenzene & 121 & 9400 & 14300 \\
\hline 1,3-Dinitrobenzene & $<19.8$ & $<19.8$ & $<19.9$ \\
\hline Nitrobenzene & $<19.8$ & $<19.8$ & $<19.9$ \\
\hline 2,4,6-Trinitrotoluene & 908 & 885 & 1390 \\
\hline 4-Amino-2,6-dinitrotoluene & $<19.8$ & $<19.8$ & $<19.9$ \\
\hline 2-Amino-4,6-dinitrotoluene & $<19.8$ & 147 & 61.9 \\
\hline 2,6-Dinitrotoluene & $<19.8$ & $<19.8$ & $<19.9$ \\
\hline 2,4-Dinitrotoluene & $<19.8$ & $<19.8$ & $<19.9$ \\
\hline 2-Nitrotoluene & $<19.8$ & $<19.8$ & $<19.9$ \\
\hline 4-Nitrotoluene & $<19.8$ & $<19.8$ & $<19.9$ \\
\hline 3-Nitrotoluene & $<19.8$ & $<19.8$ & $<19.9$ \\
\hline
\end{tabular}


Bucket 1 Sieve Analysis

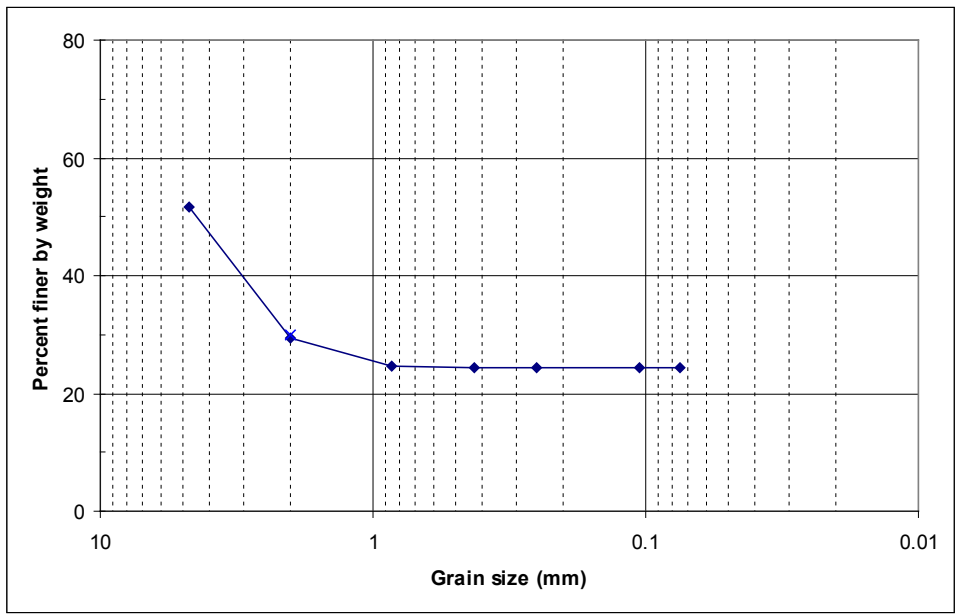

Bucket 2 Sieve Analysis

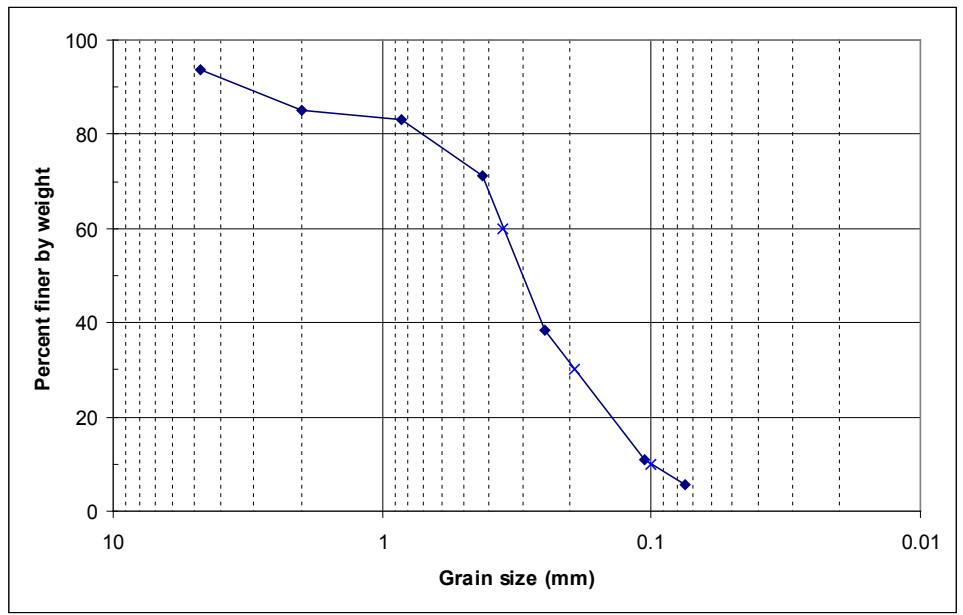

Bucket 3 Sieve Analysis

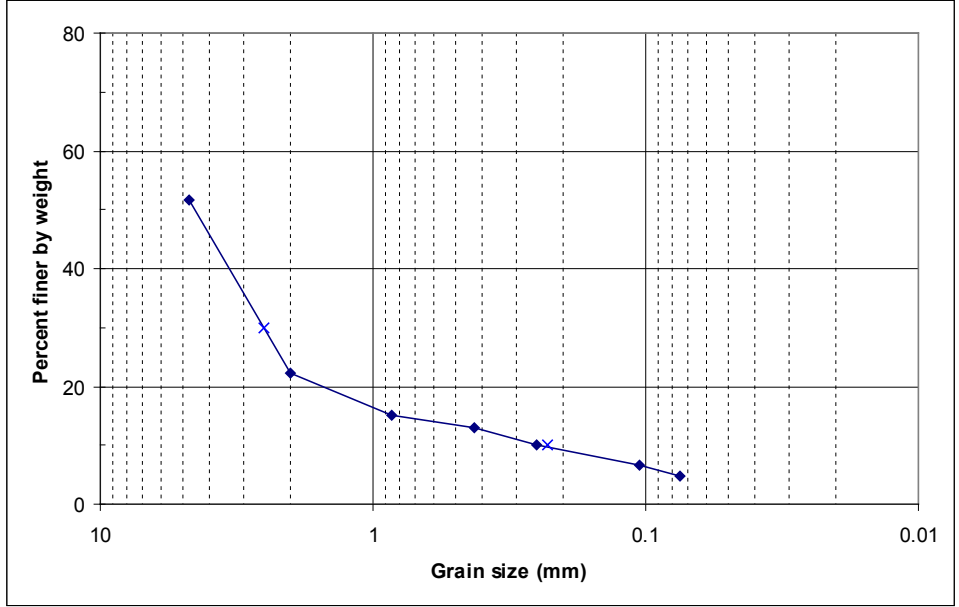

Figure 9. Sieve plots of soils collected from UMCD for use in these studies. 


\section{Removal of TNT}

Figures 10 and 11 summarize TNT removal from experimental Runs 1 and 2, respectively. Appendix A contains full data tables with the values of the triplicate analyses. Table 7 contains first order degradation rate information on the various treatments (calculations and graphs deriving this data are in Appendix B). Substantial TNT removal was found in every reactor tested, including the controls. One hypothesis developed by the team is that TNT removal in the controls results from the reducing condition generated simply from being incubated in the anaerobic hood. This suggests that TNT removal should be easily achieved with even a modest decrease in the oxidation potential in the aquifer. Removal occurred even in the autoclaved
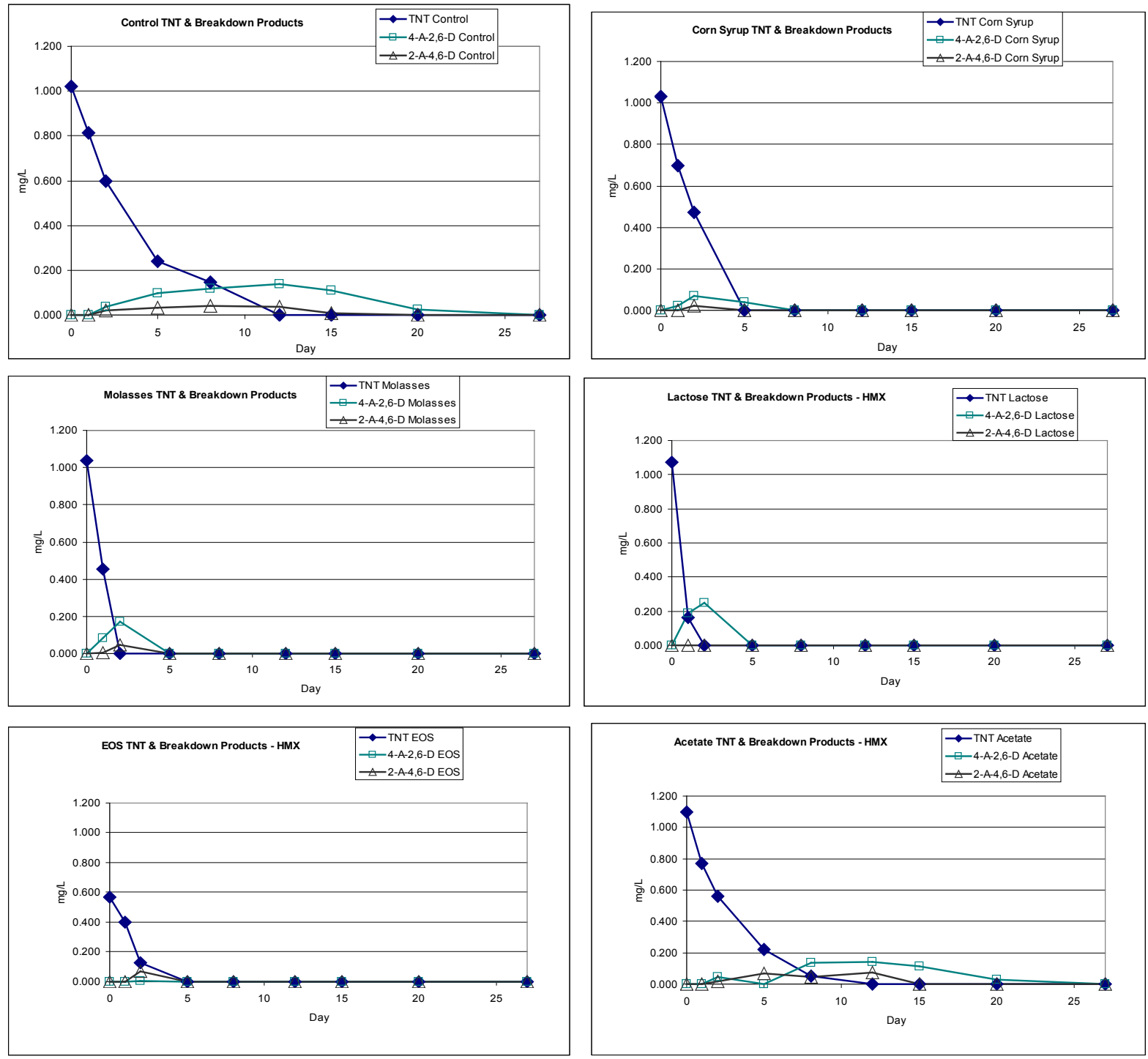

Figure 10. Run 1 TNT and breakdown products by amendment. 

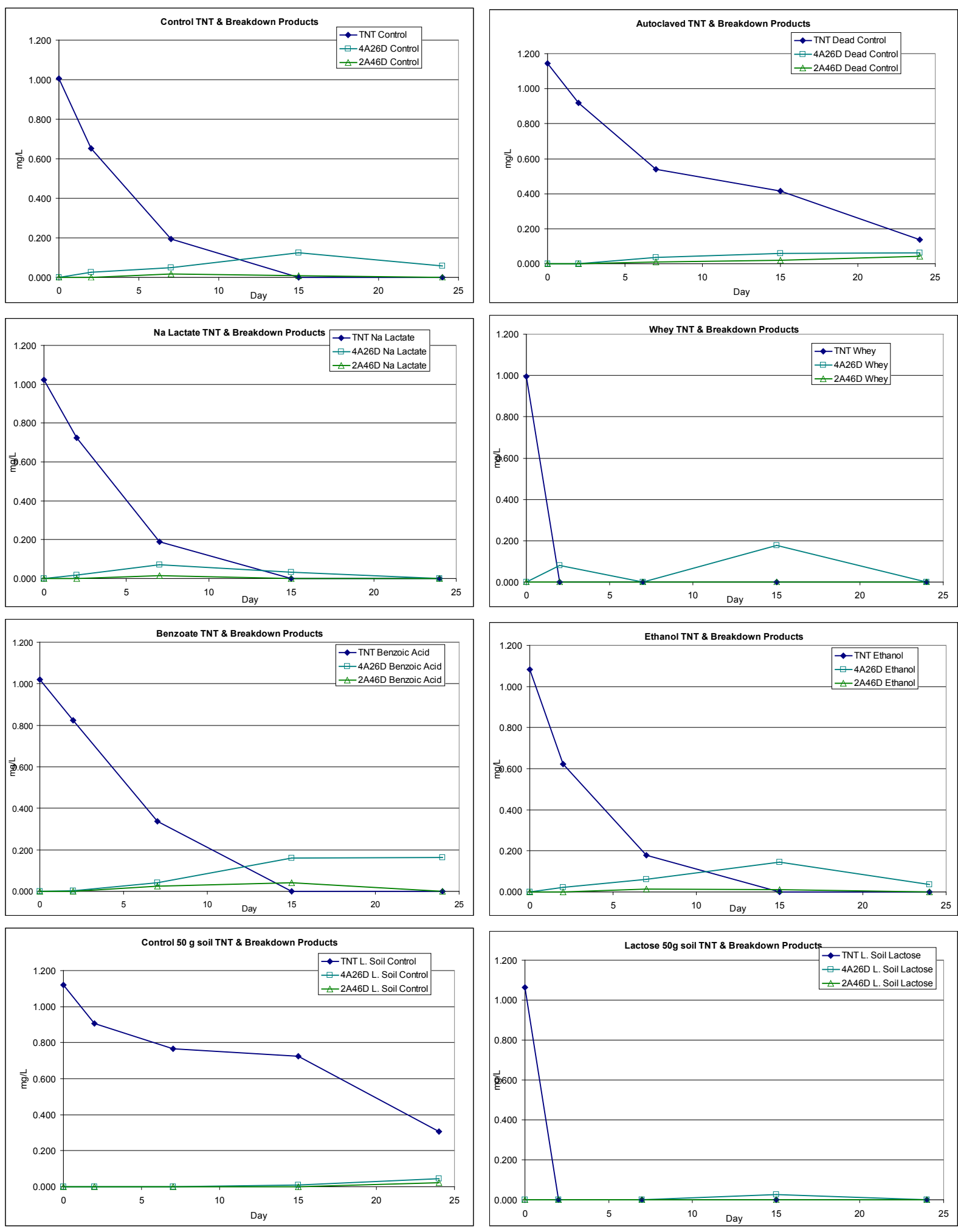

Figure 11. Run 2 TNT and breakdown products by amendment. 
Table 7. Carbon sources sorted on TNT reaction rate.

\begin{tabular}{|l|l|l|}
\hline \multirow{2}{*}{ Treatment } & \multicolumn{2}{|c|}{ TNT } \\
\cline { 2 - 3 } & Reaction Rate (day $\left.{ }^{-1}\right)$ & Half Life (days) \\
\hline L. Soil Lactose & 3.138 & 0.221 \\
\hline Whey & 3.105 & 0.223 \\
\hline Lactose & 1.879 & 0.369 \\
\hline EOS & 0.827 & 0.838 \\
\hline Corn Syrup & 0.674 & 1.028 \\
\hline Acetate & 0.391 & 1.772 \\
\hline Ethanol & 0.368 & 1.883 \\
\hline Control Run 1 & 0.258 & 2.685 \\
\hline Na Lactate & 0.254 & 2.725 \\
\hline Control Run 2 & 0.236 & 2.942 \\
\hline Benzoate & 0.234 & 2.967 \\
\hline Autoclaved & 0.154 & 4.489 \\
\hline L. Soil Control & 0.084 & 8.232 \\
\hline
\end{tabular}

control (Figure 10). This reactor had a slower removal rate compared to the unautoclaved control overall; however, by the end of the 27-day experiment, about $90 \%$ of the TNT had been removed. Autoclaving is commonly used to kill microorganisms, but it is common to find that soil microbes are resistant to complete sterilization.

The organic substrates generally increased the removal rate of the TNT. In Run 1, the most rapid removal of the TNT occurred with molasses and lactose substrates. Corn syrup and EOS also had relatively rapid removal of TNT. Acetate appeared to have about the same TNT removal as the control. In Run 2, TNT degradation rates with the whey amendment were similar to that of molasses and lactate. The removal of TNT by the other substrates used in Run 2 was similar to that of the control.

Detection limits of the Run 1 study were $10 \mu \mathrm{g} \mathrm{L} \mathrm{L}^{-1}$ for all of the data except for the last (27-day) data point. The detection limit for that point was $2 \mu \mathrm{g} \mathrm{L}-$ 1. All of the Run 1 amended treatments successfully reached levels below the $2 \mu \mathrm{g} \mathrm{L}^{-1}$ level at this time. Similarly, the detection limits for the Run 2 study were $10 \mu \mathrm{g} / \mathrm{L}$ except for the last (24-day) sample, for which a detection limit of $4 \mu \mathrm{g} \mathrm{L} \mathrm{L}^{-1}$ was obtained. 
The graphs do not have error bars. However, standard deviations are given in the data tables in Appendix A. These indicate that the standard deviations are small compared the average measurements values. For example, for the first two TNT data points for lactose, the relative standard deviation (RSD) (std dev/average) were 0.8 and $6.7 \%$ respectively.

In each case, TNT removal is accompanied by the formation of amino transformation products (4-amino-2,6-dinitrotoluene and 2-amino-4,6dinitrotoluene). Fortunately, these compounds were subsequently degraded in most cases. Lactose and molasses appeared to be particularly effective at removal of transformation products.

\section{Removal of RDX}

Figures 12 and 13 are graphs of RDX removal and breakdown product formation (complete data tables are in Appendix A) and Table 8 summarizes calculated degradation rates and half-lives for various RDX treatment approaches (calculations and graphs deriving this data is in Appendix B). Removal in all the controls tested was minimal ( $<20 \%$ during the 27-day experiment in all cases). Two amendments showed no appreciable RDX degradation ( $<20 \%$ over the 27 -day experiment): acetate and benzoic acid. Lactate and ethanol had similar patterns, showing minimal degradation during the first four sampling periods ( 15 days), but having a substantial drop during the last sampling period (24 days). The best performing amendments in terms of RDX removal were lactose (testing in both a $200 \mathrm{~g}$ solids $/ 500 \mathrm{~mL}$ solution and a $50 \mathrm{~g} / 500 \mathrm{~mL}$ solution set ups), EOS, molasses, whey, and corn syrup. Each of these reached RDX below $10 \mu \mathrm{g} \mathrm{L}^{-1}$ detection limit within 15 or less days.

Like the TNT results, review of the data (Appendix A) indicates that variation of triplicate samples was generally small. For the first three data points for lactose RDX degradation, RSDs ranged from 0.7 to $3.4 \%$. The fourth data point has an RSD of $124 \%$, but this was the last point where any detection of RDX was found, the average was $8 \mu \mathrm{g} \mathrm{L}^{-1}$ with a std. dev. of $10 \mu \mathrm{g} \mathrm{L}^{-1}$. The detection limits for RDX were the same as those for TNT.

In most cases, comparing the TNT and RDX plots for given contaminants suggest that RDX degradation begins or accelerates after TNT is largely removed from the system. EOS provides a sharp result. TNT degradation in EOS began immediately, but RDX degradation was delayed for the first three sampling periods. After the TNT was largely removed, RDX 
degradation occurred rapidly. This is consistent with results found by SagiBen Moshe et al. (2009). The pattern was found with other substrates, although it appeared perhaps not as strongly the EOS result.

We tracked three nitroso-substituted, transformation products of RDX: MNX, DNX, and TNX. As RDX was degraded, these compounds were sequentially formed, then degraded. Degradation did not reach non-detect levels in most cases; however, it was clear that degradation was occurring.
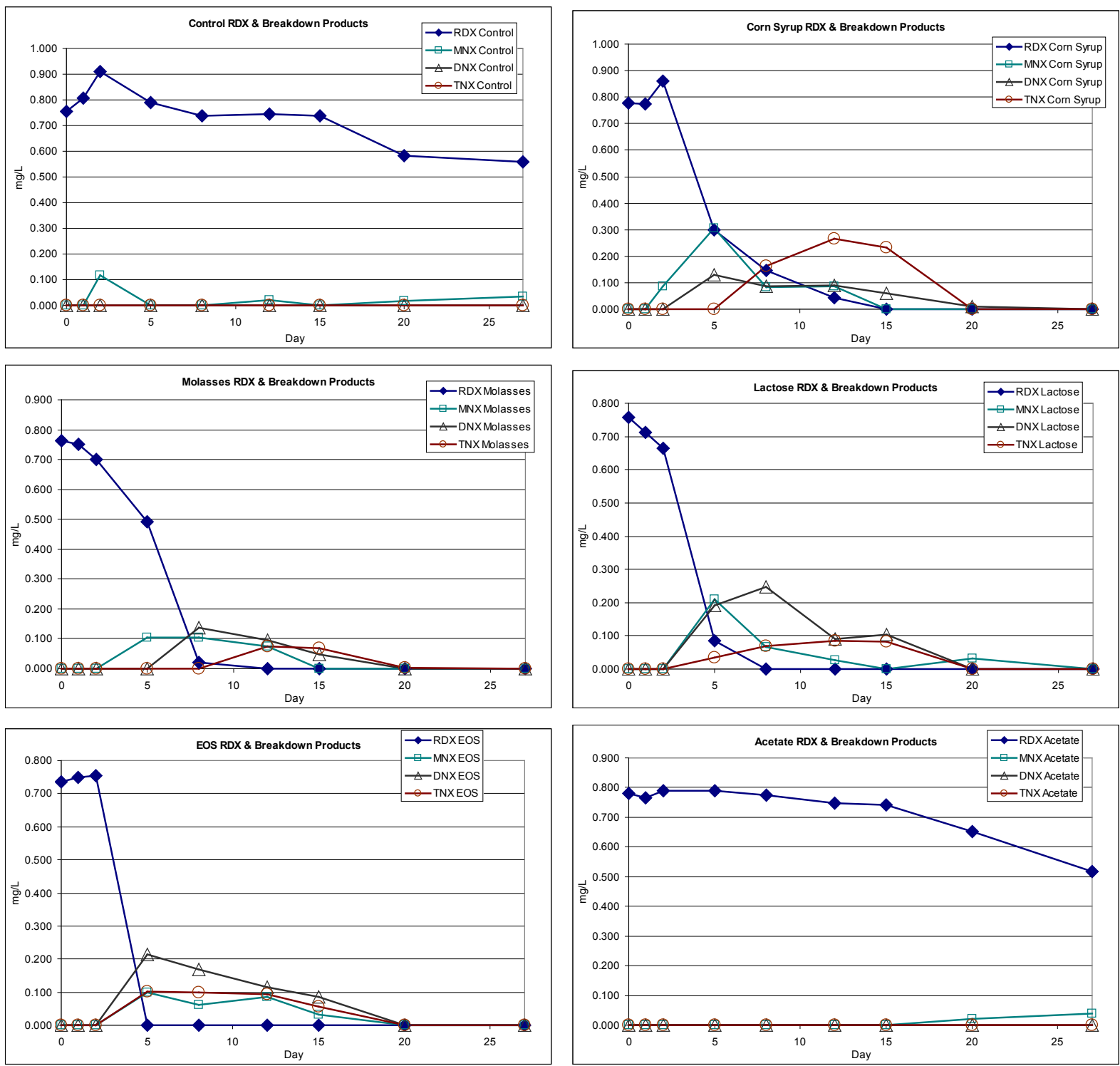

Figure 12. Run 1 RDX and breakdown products by amendment. 

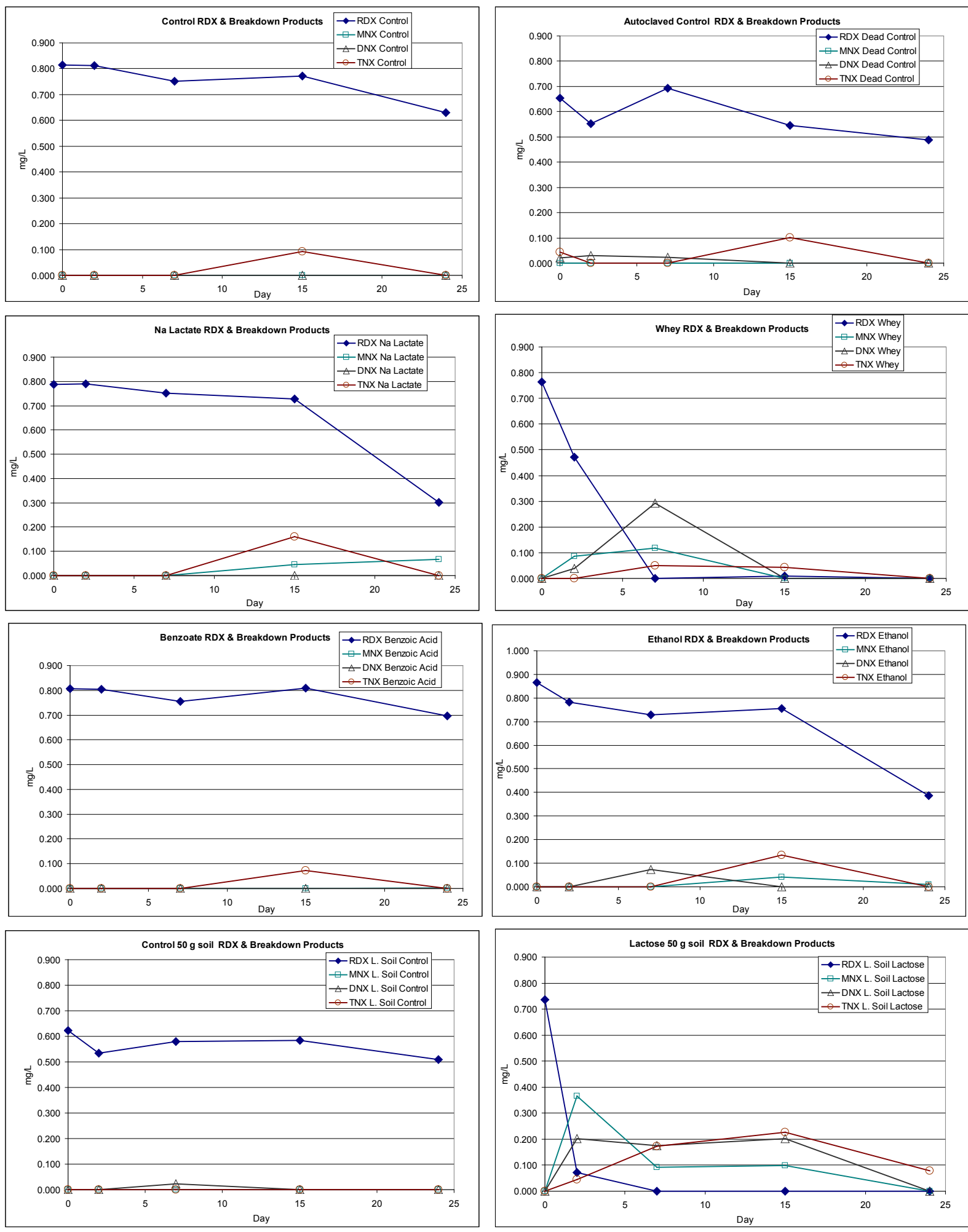

Figure 13. Run 2 RDX and breakdown products by amendment. 
Table 8. Carbon sources sorted on RDX reaction rate.

\begin{tabular}{|l|l|l|}
\hline \multirow{2}{*}{} & \multicolumn{2}{|c|}{ RDX } \\
\cline { 2 - 3 } & Reaction Rate (day ${ }^{-1}$ ) & Half Life (days) \\
\hline L. Soil Lactose & 1.158 & 0.598 \\
\hline EOS & 0.983 & 0.705 \\
\hline Lactose & 0.377 & 1.838 \\
\hline Molasses & 0.326 & 2.124 \\
\hline Whey & 0.240 & 2.889 \\
\hline Corn Syrup & 0.220 & 3.146 \\
\hline Na Lactate & 0.029 & 24.151 \\
\hline Ethanol & 0.027 & 25.961 \\
\hline Autoclaved & 0.011 & 61.340 \\
\hline Acetate & 0.010 & 70.015 \\
\hline Control Run 2 & 0.009 & 78.767 \\
\hline Control Run 1 & 0.008 & 83.51 \\
\hline L. Soil Control & 0.008 & 88.865 \\
\hline Benzoate & 0.005 & 150.684 \\
\hline & &
\end{tabular}

\section{Mass Balance of Explosives}

Table 9 summarizes mass balance information for TNT during both Test 1 and 2. If the Mass After Treatment was higher than the Time o Mass in the Soil, then some of the contaminant removal could be attributed to adsorption. In three cases, higher TNT concentrations were found in the soil after the treatment: the dead control, the soil control and the whey amendment treatment. All had higher TNT concentrations, and all were tested in Test 2. However, in each of these cases, the amount of accumulation was far less than the TNT removed from solution during the experiment.

Table 10 summarizes the mass balance for RDX. The mass of RDX after treatment was less than the time o concentration in each experiment.

\section{Other Measurements}

\section{Total Organic Carbon (TOC)}

There are several potential sources of TOC in the reactor systems, including native organic material (humic acids, plant material, etc) in the soil and groundwater used in the experiment and microorganisms themselves. However, the amendments added to the reactors were expected to be the greatest contributors to TOC. Therefore, TOC was used as a surrogate 
measurement for amendment concentration. Tables 11 and 12 summarize the TOC of the reactors for Runs 1 and 2, respectively. As expected, adding the organic co-substrates increased the TOC in the reactor systems as compared to the control, from approximately $20 \mathrm{mg} / \mathrm{L}$ to 439 (acetate) up to $1646 \mathrm{mg} / \mathrm{L}$ (lactose). No consistent pattern was found in terms of TOC concentrations in the amended reactors over time. Corn syrup, molasses, and lactose (200 g solids/500 $\mathrm{mL}$ solution) all appeared to have an appreciable drop from their time o samples compared to subsequent measurements. This pattern suggests amendment loss over time due to its use as a food source, causing losses due to conversion to $\mathrm{CO}_{2}$. EOS showed an appreciable drop from the time o to time 12 sample, but the 27-day sample had an increased value close to the concentration of the time 0 sample. For acetate, whey, and the $50 \mathrm{~g} / 500 \mathrm{~mL}$ lactose reactor, the TOC concentrations remained more or less constant during the 27-day experiment. Several amendment reactors actually had an increase in TOC over time, including benzoic acid, ethanol, and sodium lactate.

Table 9. Mass balance summary for TNT.

\begin{tabular}{|l|l|l|l|l|l|l|}
\hline \multicolumn{7}{|c|}{ TNT all units are mg } \\
\hline & $\begin{array}{l}\text { Time 0 } \\
\text { Mass in } \\
\text { Soil }\end{array}$ & $\begin{array}{l}\text { Mass After } \\
\text { Treatment }\end{array}$ & $\begin{array}{l}\text { Mass } \\
\text { Balance }\end{array}$ & $\begin{array}{l}\text { Accumulation? } \\
\text { (after > Time 0) }\end{array}$ & $\begin{array}{l}\text { Mass of } \\
\text { TNT in } \\
\text { Solution }\end{array}$ & $\begin{array}{l}\text { Is Accum. } \\
\text { > TNT in } \\
\text { Solution? }\end{array}$ \\
\hline \multicolumn{7}{|c|}{ Test } \\
\hline Control & 0.083 & 0.071 & -0.012 & no & 0.5 & N/A \\
\hline Corn Syrup & 0.083 & 0.023 & -0.060 & no & 0.5 & N/A \\
\hline Molasses & 0.083 & 0.029 & -0.054 & no & 0.5 & N/A \\
\hline Lactose & 0.083 & 0.033 & -0.050 & no & 0.5 & N/A \\
\hline EOS & 0.083 & 0.032 & -0.051 & no & 0.5 & N/A \\
\hline Acetate & 0.083 & 0.072 & -0.011 & no & 0.5 & N/A \\
\hline & & & Test 2 & & & \\
\hline Control & 0.083 & 0.078 & -0.005 & no & 0.5 & N/A \\
\hline Benzoic Acid & 0.083 & 0.076 & -0.007 & no & 0.5 & N/A \\
\hline Ethanol & 0.083 & 0.063 & -0.020 & no & 0.5 & N/A \\
\hline Lactose & 0.083 & ND & -0.083 & no & 0.5 & N/A \\
\hline Dead Control & 0.083 & 0.104 & 0.021 & yes & 0.5 & no \\
\hline Soil Control & 0.083 & 0.131 & 0.048 & yes & 0.5 & no \\
\hline Whey & 0.083 & 0.112 & 0.029 & yes & 0.5 & no \\
\hline Na Lactate & 0.083 & 0.046 & -0.037 & no & 0.5 & N/A \\
\hline
\end{tabular}

*ND=non detect $* \mathrm{~N} / \mathrm{A}=$ not applicable 
Table 10. Mass balance summary for RDX.

\begin{tabular}{|c|c|c|c|c|c|c|}
\hline \multicolumn{7}{|c|}{ RDX all units are $\mathrm{mg}$} \\
\hline & $\begin{array}{l}\text { Time } 0 \text { Mass } \\
\text { in Soil }\end{array}$ & $\begin{array}{l}\text { Mass After } \\
\text { Treatment }\end{array}$ & \begin{tabular}{|l|} 
Mass \\
Balance
\end{tabular} & $\begin{array}{l}\text { Accumulation? } \\
\text { (after }>\text { Time 0) }\end{array}$ & $\begin{array}{l}\text { Mass of RDX } \\
\text { in Solution }\end{array}$ & $\begin{array}{l}\text { Is Accum > RDX } \\
\text { in Solution? }\end{array}$ \\
\hline \multicolumn{7}{|c|}{ Test 1} \\
\hline Control & 0.901 & 0.157 & -0.744 & no & 0.4 & N/A \\
\hline Corn syrup & 0.901 & 0.027 & -0.874 & no & 0.4 & $\mathrm{~N} / \mathrm{A}$ \\
\hline Molasses & 0.901 & 0.037 & -0.864 & no & 0.4 & N/A \\
\hline Lactose & 0.901 & 0.049 & -0.852 & no & 0.4 & N/A \\
\hline EOS & 0.901 & 0.046 & -0.855 & no & 0.4 & N/A \\
\hline Acetate & 0.901 & 0.091 & -0.810 & no & 0.4 & N/A \\
\hline \multicolumn{7}{|c|}{ Test 2} \\
\hline Control & 0.901 & 0.198 & -0.703 & no & 0.4 & $\mathrm{~N} / \mathrm{A}$ \\
\hline Benzoic Acid & 0.901 & 0.172 & -0.729 & no & 0.4 & N/A \\
\hline Ethanol & 0.901 & 0.126 & -0.775 & no & 0.4 & N/A \\
\hline Lactose & 0.901 & 0.076 & -0.825 & no & 0.4 & N/A \\
\hline Dead Sea & 0.901 & 0.652 & -0.249 & no & 0.4 & N/A \\
\hline Soil Control & 0.901 & 0.508 & -0.393 & no & 0.4 & N/A \\
\hline Whey & 0.901 & 0.098 & -0.803 & no & 0.4 & N/A \\
\hline Na Lactate & 0.901 & 0.065 & -0.836 & no & 0.4 & N/A \\
\hline
\end{tabular}

Table 11. Run $1 \mathrm{TOC}$ of all replicate reactors $(\mathrm{mg} / \mathrm{L})$.

\begin{tabular}{|c|c|c|c|c|c|}
\hline Day & \multicolumn{3}{|c|}{ Control } & Average & St Dev \\
\hline 0 & 26 & 17 & 18 & 20 & 4 \\
\hline 12 & 16 & 18 & 15 & 16 & 1 \\
\hline 27 & 28 & 23 & 21 & 24 & 3 \\
\hline Day & \multicolumn{3}{|c|}{ Corn Syrup } & Average & St Dev \\
\hline 0 & 1,408 & 689 & 911 & 1,002 & 300 \\
\hline 12 & 573 & 535 & 536 & 548 & 18 \\
\hline 27 & 547 & 550 & 704 & 601 & 73 \\
\hline Day & \multicolumn{3}{|c|}{ Molasses } & Average & St Dev \\
\hline 0 & 754 & 840 & 1,335 & 977 & 256 \\
\hline 12 & 556 & 636 & 559 & 584 & 37 \\
\hline 27 & 551 & 625 & 544 & 573 & 37 \\
\hline Day & \multicolumn{3}{|c|}{ Lactose } & Average & St Dev \\
\hline 0 & 1,494 & 1,544 & 1,901 & 1,646 & 181 \\
\hline 12 & 1,146 & 1,032 & 1,283 & 1,154 & 103 \\
\hline 27 & 1,176 & 1,036 & 1,275 & 1,162 & 98 \\
\hline Day & \multicolumn{3}{|c|}{ EOS } & Average & St Dev \\
\hline 0 & 603 & 599 & 416 & 539 & 87 \\
\hline 12 & 205 & 189 & 178 & 191 & 11 \\
\hline
\end{tabular}




\begin{tabular}{|c|c|c|c|c|c|}
\hline 27 & 527 & 435 & 348 & 436 & 73 \\
\hline Day & \multicolumn{3}{|c|}{ Acetate } & Average & St Dev \\
\hline 0 & 435 & 453 & 424 & 438 & 12 \\
\hline 12 & 439 & 443 & 442 & 441 & 2 \\
\hline 27 & 420 & 442 & 432 & 432 & 9 \\
\hline
\end{tabular}

Table 12. Run 2 TOC of all replicate reactors $(\mathrm{mg} / \mathrm{L})$.

\begin{tabular}{|c|c|c|c|c|c|}
\hline Day & \multicolumn{3}{|c|}{ Control } & Average & St Dev \\
\hline 0 & 27.8 & 9.3 & 7.4 & 14.8 & 11.2 \\
\hline 15 & 48.0 & 38.9 & 40.3 & 42.4 & 4.9 \\
\hline 27 & 44.9 & 45.7 & 40.9 & 43.8 & 2.5 \\
\hline Day & \multicolumn{3}{|c|}{ Benzoic } & Average & St Dev \\
\hline 0 & 36.1 & 42.1 & 61.8 & 46.7 & 13.5 \\
\hline 15 & 87.2 & 112.4 & 110.3 & 103.3 & 14.0 \\
\hline 27 & 92.7 & 120.2 & 117.2 & 110.0 & 15.1 \\
\hline Day & \multicolumn{3}{|c|}{ Ethanol } & Average & St Dev \\
\hline 0 & 1785.6 & 1680.6 & 1447.7 & 1638.0 & 172.9 \\
\hline 15 & 3040.8 & 3066.0 & 2940.0 & 3015.6 & 66.7 \\
\hline 27 & 3063.9 & 3089.1 & 3034.5 & 3062.5 & 27.3 \\
\hline Day & \multicolumn{3}{|c|}{ Whey } & Average & St Dev \\
\hline 0 & 204.1 & 205.7 & 224.1 & 211.3 & 11.1 \\
\hline 15 & 349.9 & 329.3 & 10.2 & 229.8 & 190.4 \\
\hline 27 & 289.6 & 338.3 & 302.0 & 310.0 & 25.3 \\
\hline Day & \multicolumn{3}{|c|}{$\mathrm{Na}$ Lactate } & Average & St Dev \\
\hline 0 & 641.2 & 614.6 & 633.5 & 629.8 & 13.7 \\
\hline 15 & 1140.7 & 1061.1 & 1176.0 & 1126.0 & 58.8 \\
\hline 27 & 1086.8 & 1089.5 & 1072.7 & 1083.0 & 9.0 \\
\hline Day & \multicolumn{3}{|c|}{ Lactose $50 \mathrm{~g}$ soil } & Average & St Dev \\
\hline 0 & 719.1 & 683.5 & 737.6 & 713.4 & 27.5 \\
\hline 15 & 846.7 & 872.1 & 872.8 & 863.9 & 14.9 \\
\hline 27 & 851.1 & 886.4 & 887.5 & 875.0 & 20.7 \\
\hline Day & \multicolumn{3}{|c|}{ Autoclaved Control } & Average & St Dev \\
\hline 0 & 26.1 & 25.9 & 20.6 & 24.2 & 3.1 \\
\hline 15 & 45.2 & 42.6 & 47.1 & 45.0 & 2.3 \\
\hline 27 & 46.5 & 44.9 & 26.4 & 39.3 & 11.2 \\
\hline Day & \multicolumn{3}{|c|}{ Control 50 g soil } & Average & St Dev \\
\hline 0 & 20.3 & 63.9 & 6.9 & 30.4 & 29.8 \\
\hline 15 & 35.9 & 34.4 & 43.8 & 38.0 & 5.1 \\
\hline 27 & 36.8 & 37.2 & 34.8 & 36.3 & 1.3 \\
\hline
\end{tabular}




\section{Dissolved Oxygen Concentration (DO) and Eh}

Tables 13 and 14 summarize the Dissolved Oxygen data for Runs 1 and 2 respectively. Initial DO values were, unfortunately, not triplicated for time o samples for Run 1; this was done due to the rapid variability in the reactor. A steady state measurement was not possible because probe readings were unstable. The control had a relatively low initial DO of 0.4 $\mathrm{mg} / \mathrm{L}$. The measurements were conducted under the anaerobic hood, which is the likely reason for the low DO levels. Initial DO measurements of other treatments ranged from 0.4 to $0.9 \mathrm{mg} / \mathrm{L}$.

Table 13. Run 1 Dissolved Oxygen ( $\mathrm{mg} / \mathrm{L})$.

\begin{tabular}{|c|c|c|c|c|c|}
\hline Day & \multicolumn{3}{|c|}{ Control } & Average & St Dev \\
\hline 0 & 0.36 & & & 0.36 & \\
\hline 12 & 0.67 & 0.15 & 0.12 & 0.31 & 0.31 \\
\hline 27 & 0.07 & 0.06 & 0.53 & 0.22 & 0.27 \\
\hline Day & \multicolumn{3}{|c|}{ Corn Syrup } & Average & St Dev \\
\hline 0 & 0.40 & & & 0.40 & \\
\hline 12 & 0.32 & 0.31 & 0.17 & 0.27 & 0.08 \\
\hline 27 & 0.66 & 0.52 & 0.40 & 0.53 & 0.13 \\
\hline Day & \multicolumn{3}{|c|}{ Molasses } & Average & St Dev \\
\hline 0 & 0.55 & & & 0.55 & \\
\hline 12 & 0.17 & 0.17 & 0.22 & 0.19 & 0.03 \\
\hline 27 & 0.10 & 0.16 & 0.14 & 0.13 & 0.03 \\
\hline Day & \multicolumn{3}{|c|}{ Lactose } & Average & St Dev \\
\hline 0 & 0.50 & & & 0.50 & \\
\hline 12 & 0.11 & 0.11 & 0.26 & 0.16 & 0.09 \\
\hline 27 & 0.02 & 0.20 & 0.20 & 0.14 & 0.10 \\
\hline Day & \multicolumn{3}{|c|}{ EOS } & Average & St Dev \\
\hline 0 & 0.88 & & & 0.88 & \\
\hline 12 & 0.04 & 0.17 & 0.08 & 0.10 & 0.07 \\
\hline 27 & 0.43 & 0.53 & 0.49 & 0.48 & 0.05 \\
\hline Day & \multicolumn{3}{|c|}{ Acetate } & Average & St Dev \\
\hline 0 & 0.78 & & & 0.78 & \\
\hline 12 & 0.24 & 0.27 & 0.20 & 0.24 & 0.04 \\
\hline 27 & 0.71 & 0.74 & 0.60 & 0.68 & 0.07 \\
\hline
\end{tabular}


Table 14. Run 2 Dissolved Oxygen (mg/L).

\begin{tabular}{|c|c|c|c|c|c|}
\hline \multirow{2}{*}{$\begin{array}{l}\text { Day } \\
0\end{array}$} & \multicolumn{3}{|c|}{ Control } & \multirow[t]{2}{*}{ Average } & \multirow[t]{2}{*}{ St Dev } \\
\hline & & & \\
\hline 15 & 0.26 & 0.31 & 0.21 & 0.26 & 0.05 \\
\hline 27 & 0.35 & 0.22 & 0.20 & 0.26 & 0.08 \\
\hline Day & \multicolumn{3}{|c|}{ Benzoic acid } & Average & St Dev \\
\hline \multicolumn{6}{|l|}{0} \\
\hline 15 & 0.27 & 0.37 & 0.18 & 0.27 & 0.10 \\
\hline 27 & 0.23 & 0.27 & 0.21 & 0.24 & 0.03 \\
\hline Day & \multicolumn{3}{|c|}{ Ethanol } & Average & St Dev \\
\hline \multicolumn{6}{|l|}{0} \\
\hline 15 & 0.00 & 0.01 & 0.12 & 0.04 & 0.07 \\
\hline 27 & 0.29 & 0.18 & 0.02 & 0.16 & 0.14 \\
\hline Day & \multicolumn{3}{|c|}{ Whey } & Average & St Dev \\
\hline \multicolumn{6}{|l|}{0} \\
\hline 15 & 0.06 & 0.15 & 0.00 & 0.07 & 0.08 \\
\hline 27 & 0.12 & 0.27 & 0.18 & 0.19 & 0.08 \\
\hline Day & \multicolumn{3}{|c|}{$\mathrm{Na}$ Lactate } & Average & St Dev \\
\hline 0 & & 0.43 & & 0.43 & \\
\hline 15 & 0.34 & 0.35 & 0.00 & 0.23 & 0.20 \\
\hline 27 & 0.22 & 0.39 & 0.28 & 0.30 & 0.09 \\
\hline Day & \multicolumn{3}{|c|}{ Lactose 50 g soil } & Average & St Dev \\
\hline \multicolumn{6}{|l|}{0} \\
\hline 15 & 0.27 & 0.13 & 0.35 & 0.25 & 0.11 \\
\hline 27 & 0.50 & 0.24 & 0.27 & 0.34 & 0.14 \\
\hline Day & \multicolumn{3}{|c|}{ Autoclaved Control } & Average & St Dev \\
\hline 0 & & 3.89 & & 3.89 & \\
\hline 15 & 0.34 & 0.80 & 0.29 & 0.48 & 0.28 \\
\hline 27 & 0.32 & 0.46 & 0.20 & 0.33 & 0.13 \\
\hline Day & \multicolumn{3}{|c|}{ Control 50 g soil } & Average & St Dev \\
\hline 0 & & & & & \\
\hline 15 & 0.26 & 0.35 & 0.28 & 0.30 & 0.05 \\
\hline 27 & 0.07 & 0.33 & 0.73 & 0.38 & 0.33 \\
\hline
\end{tabular}


During the Run 1 experiment, the DO levels in the control dropped to $0.3 \mathrm{mg} / \mathrm{L}$ at 12 days and to 0.2 at 27 days. However, because the standard deviation of both of these measurements was 0.3 , it is likely that this change was not significant.

The DO levels of the amended reactors in Run 1 decreased for the 12-day measurement. Except for corn syrup, this decrease would likely have been statistically significant. However, for the 27-day measurement, the DO measurements for corn syrup, EOS, and acetate actually increased compared to the 12-day measurement. The 27-day DO measurements for molasses and lactose continued to decrease.

As mentioned above, unfortunately, the team failed to record a time zero measurement for Run 2, except for the autoclaved control. This measurement was $3.9 \mathrm{mg} / \mathrm{L}$. The subsequent DO measurements for all the reactors were similar levels to that found in Run 1.

Tables 15 and 16 summarize Eh measurements from Runs 1 and 2. Unfortunately, data from time zero was not taken. Again, the variability in the reactors made it difficult to obtain measurements with any reliability. This variability is a common confounding factor in Eh measurements (Vance 1996). Measurements taken from the Run 1 control on days 12 and 27 had Eh's of -52 and -95, respectively. These levels are in the zone of anaerobic reactions, in the range of sulfate reduction (Vance, 1996). Amendments depressed Eh further to levels ranging from -147 to -277, into the range of methane reduction. Measurements of controls in Run 2 were lower, on the same levels of those taken in the amended reactors.

\section{pH}

Tables 17 and 18 summarize the $\mathrm{pH}$ data for Runs 1 and 2, respectively. The initial measurements were not triplicated; however, subsequent measurements were. For Run 1, the initial $\mathrm{pH}$ measurement of the nonautoclaved control was 8.5. The initial measurements for the amended treatments in Run 1 ranged from 7.1 to 8.9. The $\mathrm{pH}$ declined slightly (from 0.9 to $1.7 \mathrm{pH}$ units) for each amended treatment over the 27-day run.

During Run 2, the pH's for most of the reactors remained close to the initial measurement level. Two exceptions to this were measurements for Whey and Lactose (50g soil/500 mL solution), which had modest, but noticable $\mathrm{pH}$ declines throughout the 27-day study. 
Table 15. Run 1 Eh.

\begin{tabular}{|c|c|c|c|c|c|c|c|}
\hline \multirow{2}{*}{$\begin{array}{l}\text { Day } \\
0\end{array}$} & \multicolumn{3}{|c|}{ Control } & \multirow[t]{2}{*}{ Average } & \multirow[t]{2}{*}{ St Dev } & \multirow[t]{2}{*}{ mVAgCl } & \multirow[t]{2}{*}{$\mathrm{mV}$ ref Eh } \\
\hline & & & & & & & \\
\hline 12 & -49 & -50 & -56 & -52 & 4 & -92 & 108 \\
\hline 27 & -71 & -92 & \begin{tabular}{|l|}
-122 \\
\end{tabular} & -95 & 26 & -135 & 65 \\
\hline Day & \multicolumn{3}{|c|}{ Corn Syrup } & Average & St Dev & mVAgCl & $\mathrm{mV}$ ref Eh \\
\hline \multicolumn{8}{|l|}{0} \\
\hline 12 & -366 & -175 & -215 & -252 & 101 & -292 & -92 \\
\hline 27 & -171 & -165 & -182 & -172 & 9 & -212 & -12 \\
\hline Day & \multicolumn{3}{|c|}{ Molasses } & Average & St Dev & mVAgCl & $\mathrm{mV}$ ref Eh \\
\hline \multicolumn{8}{|l|}{0} \\
\hline 12 & -252 & -284 & -256 & -264 & 17 & -304 & -104 \\
\hline 27 & -211 & -202 & -213 & -209 & 6 & -249 & -49 \\
\hline Day & \multicolumn{3}{|c|}{ Lactose } & Average & St Dev & mVAgCl & $\mathrm{mV}$ ref Eh \\
\hline \multicolumn{8}{|l|}{0} \\
\hline 12 & -225 & -256 & -198 & -226 & 29 & -266 & -66 \\
\hline 27 & -137 & -159 & -145 & -147 & 11 & -187 & 13 \\
\hline Day & \multicolumn{3}{|c|}{ EOS } & Average & St Dev & mVAgCl & $\mathrm{mV}$ ref Eh \\
\hline \multicolumn{8}{|l|}{0} \\
\hline 12 & -264 & -280 & -286 & -277 & 12 & -317 & -117 \\
\hline 27 & \begin{tabular}{|l|}
-174 \\
\end{tabular} & -156 & -176 & -169 & 11 & -209 & -9 \\
\hline Day & \multicolumn{3}{|c|}{ Acetate } & Average & St Dev & mVAgCl & $\mathrm{mV}$ ref Eh \\
\hline \multicolumn{8}{|l|}{0} \\
\hline 12 & -259 & -239 & -225 & -241 & 17 & -281 & -81 \\
\hline 27 & \begin{tabular}{|l|}
-197 \\
\end{tabular} & -210 & -254 & -220 & 30 & -260 & -60 \\
\hline
\end{tabular}

\section{Metals and Conductivity Data}

Table 19 and 20 summarize metals and conductivity data from Run 1. For Run 1, it is clear that the metals increased in solution over the 27-day run. Increases were found for $\mathrm{Mn}$ in the control. Greater increases were found in the amendment treatments for Mn, Fe, and Ca. Presumably, these metals were leached from the soils that were in the system. Although some leaching appeared to occur in the control, much more was found in the amended reactors. So, either the amendments themselves facilitated leaching or the bioactivity spurred from the amendments resulted in enhanced metals leaching. Bednar et al. (2007) indicated that added organic acids could result in increased uranium solubility. Similarly, bacterial activity can produce organic acids and biological chelating agents that increase 
Table 16. Run 2 Eh.

\begin{tabular}{|c|c|c|c|c|c|c|c|}
\hline \multirow{2}{*}{$\begin{array}{l}\text { Day } \\
0\end{array}$} & \multicolumn{3}{|c|}{ Control } & \multirow[t]{2}{*}{ Average } & \multirow[t]{2}{*}{ St Dev } & \multirow[t]{2}{*}{ mVAgCl } & \multirow[t]{2}{*}{$\mathrm{mV}$ ref Eh } \\
\hline & & & & & & & \\
\hline 15 & -373.5 & -298.9 & -164.2 & -279 & 106 & -319 & -119 \\
\hline 27 & -738.8 & -322.1 & -271.4 & -444 & 256 & -484 & -284 \\
\hline Day & \multicolumn{3}{|c|}{ Benzoic acid } & Average & St Dev & mVAgCl & $\mathrm{mV}$ ref Eh \\
\hline \multicolumn{8}{|l|}{0} \\
\hline 15 & -176.0 & -295.8 & -311.5 & -261 & 74 & -301 & -101 \\
\hline 27 & \begin{tabular}{|l|}
-303.3 \\
\end{tabular} & -411.3 & -356.7 & -357 & 54 & -397 & -197 \\
\hline Day & \multicolumn{3}{|c|}{ Ethanol } & Average & St Dev & mVAgCl & $\mathrm{mV}$ ref Eh \\
\hline \multicolumn{8}{|l|}{0} \\
\hline 15 & -323.3 & -277.8 & -290.9 & -297 & 23 & -337 & -137 \\
\hline 27 & -379.7 & -387.8 & -379.7 & -382 & 5 & -422 & -222 \\
\hline Day & \multicolumn{3}{|c|}{ Whey } & Average & St Dev & mVAgCl & $\mathrm{mV}$ ref Eh \\
\hline \multicolumn{8}{|l|}{0} \\
\hline 15 & -207.5 & -180.2 & -198.9 & -196 & 14 & -236 & -36 \\
\hline 27 & -232.8 & -210.2 & -227.6 & -224 & 12 & -264 & -64 \\
\hline Day & \multicolumn{3}{|c|}{$\mathrm{Na}$ Lactate } & Average & St Dev & mVAgCl & $\mathrm{mV}$ ref Eh \\
\hline \multicolumn{8}{|l|}{0} \\
\hline 15 & -163.2 & -271.4 & -111.8 & -182 & 81 & -222 & -22 \\
\hline 27 & -259.8 & -196.9 & -157.5 & -205 & 52 & -245 & -45 \\
\hline Day & \multicolumn{3}{|c|}{ Lactose $50 \mathrm{~g}$ soil } & Average & St Dev & mVAgCl & $\mathrm{mV}$ ref Eh \\
\hline \multicolumn{8}{|l|}{0} \\
\hline 15 & -211.4 & -226.4 & -238.3 & -225 & 13 & -265 & -65 \\
\hline 27 & -187.0 & -186.1 & -178.9 & -184 & 4 & -224 & -24 \\
\hline Day & \multicolumn{3}{|c|}{ Autoclaved Control } & Average & St Dev & mVAgCl & $\mathrm{mV}$ ref Eh \\
\hline \multicolumn{8}{|l|}{0} \\
\hline 15 & -106.9 & -65.6 & -154.9 & -109 & 45 & -149 & 51 \\
\hline 27 & -160.0 & -166.7 & -185.6 & -171 & 13 & -211 & -11 \\
\hline Day & \multicolumn{3}{|c|}{ Control 50 g soil } & Average & St Dev & mVAgCl & $\mathrm{mV}$ ref Eh \\
\hline \multicolumn{8}{|l|}{0} \\
\hline 15 & -172.8 & -189.1 & -148.6 & -170 & 20 & -210 & -10 \\
\hline 27 & -178.6 & -143.3 & -172.0 & -165 & 19 & -205 & -5 \\
\hline
\end{tabular}


Table 17. Run $1 \mathrm{pH}$.

\begin{tabular}{|c|c|c|c|c|c|}
\hline Day & \multicolumn{3}{|c|}{ Control } & Average & St Dev \\
\hline 0 & & 8.5 & & 8.5 & \\
\hline 12 & 8.4 & 8.4 & 8.5 & 8.4 & 0.0 \\
\hline 27 & 7.9 & 8.1 & 8.2 & 8.1 & 0.2 \\
\hline Day & \multicolumn{3}{|c|}{ Corn syrup } & Average & St Dev \\
\hline 0 & & 8.8 & & 8.8 & \\
\hline 12 & 6.3 & 6.6 & 7.2 & 6.7 & 0.5 \\
\hline 27 & 6.9 & 7.1 & 7.3 & 7.1 & 0.2 \\
\hline Day & \multicolumn{3}{|c|}{ Molasses } & Average & St Dev \\
\hline 0 & & 8.3 & & 8.3 & \\
\hline 12 & 6.3 & 6.7 & 6.6 & 6.6 & 0.2 \\
\hline 27 & 7.4 & 7.4 & 7.5 & 7.4 & 0.1 \\
\hline Day & \multicolumn{3}{|c|}{ Lactose } & Average & St Dev \\
\hline 0 & & 7.4 & & 7.4 & \\
\hline 12 & 5.4 & 5.7 & 5.4 & 5.5 & 0.2 \\
\hline 27 & 6.0 & 6.2 & 6.0 & 6.1 & 0.1 \\
\hline Day & \multicolumn{3}{|c|}{ EOS } & Average & St Dev \\
\hline 0 & & 7.1 & & 7.1 & \\
\hline 12 & 6.6 & 6.8 & 6.9 & 6.8 & 0.2 \\
\hline 27 & 6.4 & 6.1 & 6.4 & 6.3 & 0.2 \\
\hline Day & \multicolumn{3}{|c|}{ Acetate } & Average & St Dev \\
\hline 0 & & 8.9 & & 8.9 & \\
\hline 12 & 8.4 & 8.3 & 8.4 & 8.3 & 0.1 \\
\hline 27 & 7.4 & 8.0 & 8.1 & 7.8 & 0.4 \\
\hline
\end{tabular}

metallic solubility. As discussed above, $\mathrm{pH}$ decreases were found for some of the more effective amendments, particularly those in Run 1. Conductivity measurements for Run 1 steadily increased as well, supporting the conclusion that metals dissolved into solution over time.

Tables 21 and 22 summarize metals and conductivity data for Run 2. A similar pattern of metals increase in solution was found as in Run 1, although it was not as pronounced. Interestingly, virtually no increase was found in the autoclaved control, suggesting that retarding the biological activity decreased metals dissolution. 
Table 18. Run $2 \mathrm{pH}$.

\begin{tabular}{|c|c|c|c|c|c|}
\hline Day & \multicolumn{3}{|c|}{ Control } & Average & St Dev \\
\hline 0 & & 8.2 & & 8.2 & \\
\hline 15 & 7.7 & 7.9 & 8.0 & 7.9 & 0.2 \\
\hline 27 & 8.0 & 8.2 & 8.3 & 8.2 & 0.2 \\
\hline Day & \multicolumn{3}{|c|}{ Benzoic acid } & Average & St Dev \\
\hline 0 & & 8.0 & & 8.0 & \\
\hline 15 & 8.1 & 8.1 & 8.2 & 8.1 & 0.1 \\
\hline 27 & 8.3 & 8.3 & 8.4 & 8.3 & 0.0 \\
\hline Day & \multicolumn{3}{|c|}{ Ethanol } & Average & St Dev \\
\hline 0 & & 8.6 & & 8.6 & \\
\hline 15 & 8.3 & 8.3 & 8.3 & 8.3 & 0.0 \\
\hline 27 & 8.4 & 8.4 & 8.5 & 8.4 & 0.1 \\
\hline Day & \multicolumn{3}{|c|}{ Whey } & Average & St Dev \\
\hline 0 & & 8.3 & & 8.3 & \\
\hline 15 & 7.8 & 7.5 & 7.7 & 7.7 & 0.1 \\
\hline 27 & 8.0 & 7.7 & 8.0 & 7.9 & 0.2 \\
\hline Day & \multicolumn{3}{|c|}{$\mathrm{Na}$ Lactate } & Average & St Dev \\
\hline 0 & & 7.6 & & 7.6 & \\
\hline 15 & 8.1 & 8.1 & 8.2 & 8.2 & 0.0 \\
\hline 27 & 8.0 & 8.3 & 8.3 & 8.2 & 0.2 \\
\hline Day & \multicolumn{3}{|c|}{ Lactose 50 g soil } & Average & St Dev \\
\hline 0 & & 7.5 & & 7.5 & \\
\hline 15 & 5.4 & 5.4 & 5.4 & 5.4 & 0.0 \\
\hline 27 & 5.7 & 6.7 & 5.7 & 6.0 & 0.6 \\
\hline Day & \multicolumn{3}{|c|}{ Autoclaved Control } & Average & St Dev \\
\hline 0 & & 7.6 & & 7.6 & \\
\hline 15 & 6.6 & 7.1 & 7.3 & 7.0 & 0.4 \\
\hline 27 & 8.0 & 8.0 & 8.1 & 8.0 & 0.0 \\
\hline Day & \multicolumn{3}{|c|}{ Control 50 g soil } & Average & St Dev \\
\hline 0 & & 7.6 & & 7.6 & \\
\hline 15 & 7.7 & 8.0 & 8.1 & 8.0 & 0.2 \\
\hline 27 & 8.4 & 8.7 & 8.5 & 8.6 & 0.1 \\
\hline
\end{tabular}


Table 19. Run 1 Metals Analysis. Detection limit was $0.5 \mu \mathrm{g} / \mathrm{L}$. BD means below detection.

\begin{tabular}{|c|c|c|c|}
\hline Date & $\begin{array}{l}\mathrm{Fe} \\
(\mu \mathrm{g} / \mathrm{L})\end{array}$ & $\begin{array}{l}\mathrm{Mn} \\
(\mu \mathrm{g} / \mathrm{L})\end{array}$ & $\begin{array}{l}\mathrm{Ca} \\
(\mu \mathrm{g} / \mathrm{L})\end{array}$ \\
\hline \multicolumn{4}{|c|}{ Control } \\
\hline 0 & $B D$ & 36 & 30,293 \\
\hline 12 & $B D$ & 320 & 32,147 \\
\hline 27 & $B D$ & 244 & 28,920 \\
\hline \multicolumn{4}{|c|}{ Corn Syrup } \\
\hline 0 & $B D$ & 66 & 31,330 \\
\hline 12 & 5,903 & 10,033 & 340,800 \\
\hline 27 & 3,480 & 13,060 & 443,367 \\
\hline \multicolumn{4}{|c|}{ Molasses } \\
\hline 0 & 121 & 347 & 43,880 \\
\hline 12 & 2,347 & 11,443 & 378,600 \\
\hline 27 & 2,230 & 11,670 & 414,200 \\
\hline \multicolumn{4}{|c|}{ Lactose } \\
\hline 0 & $B D$ & 92 & 62,157 \\
\hline 12 & 20,114 & 15,637 & 642,333 \\
\hline 27 & 31,573 & 23,373 & 800,067 \\
\hline \multicolumn{4}{|c|}{ EOS } \\
\hline 0 & $B D$ & 38 & 46,123 \\
\hline 12 & 75 & 3,784 & 97,807 \\
\hline 27 & 12,106 & 12,361 & 275,133 \\
\hline \multicolumn{4}{|c|}{ Acetate } \\
\hline 0 & $B D$ & 57 & 60,703 \\
\hline 12 & $B D$ & 1,171 & 96,872 \\
\hline 27 & $B D$ & 1,018 & 100,970 \\
\hline
\end{tabular}

\section{Cost and Sources of Amendments}

The sources and costs of the amendments with the most promising performance were identified and are summarized in Tables 23 and 24. 
Table 20. Run 1 Conductivity $\mu \mathrm{S} / \mathrm{cm}$.

\begin{tabular}{|c|c|c|c|c|c|}
\hline Day & \multicolumn{3}{|c|}{ Control } & Average & St Dev \\
\hline 0 & & 413 & & 413 & \\
\hline 12 & 325 & 323 & 320 & 323 & 3 \\
\hline 27 & 332 & 323 & 320 & 325 & 6 \\
\hline Day & \multicolumn{3}{|c|}{ Corn Syrup } & Average & St Dev \\
\hline 0 & & 317 & & 317 & \\
\hline 12 & 1,705 & 1,753 & 1,420 & 1,626 & 180 \\
\hline 27 & 1,703 & 2,111 & 2,059 & 1,958 & 222 \\
\hline Day & \multicolumn{3}{|c|}{ Molasses } & Average & St Dev \\
\hline 0 & & 390 & & 390 & \\
\hline 12 & 1,767 & 1,767 & 1,789 & 1,774 & 13 \\
\hline 27 & 1,793 & 1,875 & 1,804 & 1,824 & 45 \\
\hline Day & \multicolumn{3}{|c|}{ Lactose } & Average & St Dev \\
\hline 0 & & 927 & & 927 & \\
\hline 12 & 2,958 & 2,848 & 3,540 & 3,115 & 372 \\
\hline 27 & 3,600 & 3,010 & 4,110 & 3,573 & 550 \\
\hline Day & \multicolumn{3}{|c|}{ EOS } & Average & St Dev \\
\hline 0 & & 534 & & 534 & \\
\hline 12 & 775 & 731 & 718 & 741 & 30 \\
\hline 27 & 1855 & 1384 & 1101 & 1,447 & 381 \\
\hline Day & \multicolumn{3}{|c|}{ Acetate } & Average & St Dev \\
\hline 0 & & 2131 & & 2,131 & \\
\hline 12 & 2027 & 2090 & 2060 & 2,059 & 32 \\
\hline 27 & 2036 & 2081 & 2056 & 2,058 & 23 \\
\hline
\end{tabular}


Table 21. Run 2 Metals Analysis. Detection limit was $0.5 \mu \mathrm{g} / \mathrm{L}$. BD means below detection.

\begin{tabular}{|c|c|c|c|}
\hline Date & $\begin{array}{l}\mathrm{Fe} \\
(\mu \mathrm{g} / \mathrm{L})\end{array}$ & $\begin{array}{l}M n \\
(\mu g / L)\end{array}$ & $\begin{array}{l}\mathrm{Ca} \\
(\mu \mathrm{g} / \mathrm{L})\end{array}$ \\
\hline \multicolumn{4}{|c|}{ Control } \\
\hline 0 & BD & 55 & 37,913 \\
\hline 15 & 108 & 4 & 46,013 \\
\hline 27 & 17 & 253 & 38,320 \\
\hline \multicolumn{4}{|c|}{ Benzoic Acid } \\
\hline 0 & $\mathrm{BD}$ & 26 & 41,570 \\
\hline 15 & 37 & 2 & 46,453 \\
\hline 27 & $B D$ & 436 & 33,970 \\
\hline \multicolumn{4}{|c|}{ Ethanol } \\
\hline 0 & $\mathrm{BD}$ & 12 & 42,437 \\
\hline 15 & $B D$ & $\mathrm{BD}$ & 48,467 \\
\hline 27 & $\mathrm{BD}$ & 423 & 21,970 \\
\hline \multicolumn{4}{|c|}{ Whey } \\
\hline 0 & $\mathrm{BD}$ & 21 & 59,817 \\
\hline 15 & BD & BD & 41,013 \\
\hline 27 & 71 & 3,467 & 102,873 \\
\hline \multicolumn{4}{|c|}{$\mathrm{Na}$ Lactate } \\
\hline 0 & 13 & 68 & 114,967 \\
\hline 15 & $B D$ & 12 & 54,300 \\
\hline 27 & $B D$ & 1,807 & 47,127 \\
\hline \multicolumn{4}{|c|}{ Lactose with 50 g soil } \\
\hline 0 & BD & 39 & 71,623 \\
\hline 15 & BD & 13 & 71,897 \\
\hline 27 & 23,880 & 5,655 & 105,907 \\
\hline \multicolumn{4}{|c|}{ Autoclaved Control } \\
\hline 0 & BD & 14 & 46,970 \\
\hline \multicolumn{4}{|l|}{15} \\
\hline 27 & 3 & 20 & 22,238 \\
\hline \multicolumn{4}{|c|}{ Control with $50 \mathrm{~g}$ soil } \\
\hline 0 & $B D$ & 16 & 33,943 \\
\hline \multicolumn{4}{|l|}{15} \\
\hline 27 & $B D$ & 13 & 18,843 \\
\hline
\end{tabular}


Table 22. Run 2 Conductivity $\mu \mathrm{S} / \mathrm{cm}$.

\begin{tabular}{|c|c|c|c|c|c|}
\hline Day & \multicolumn{3}{|c|}{ Control } & Average & St Dev \\
\hline 0 & & 104 & & 104 & \\
\hline 15 & 410 & 416 & 410 & 412 & 3 \\
\hline 27 & 408 & 414 & 411 & 411 & 3 \\
\hline Day & \multicolumn{3}{|c|}{ Benzoic acid } & Average & St Dev \\
\hline 0 & & 121 & & 121 & \\
\hline 15 & 458 & 467 & 471 & 465 & 7 \\
\hline 27 & 453 & 466 & 466 & 462 & 8 \\
\hline Day & \multicolumn{3}{|c|}{ Ethanol } & Average & St Dev \\
\hline 0 & & 133 & & 133 & \\
\hline 15 & 412 & 412 & 403 & 409 & 5 \\
\hline 27 & 409 & 409 & 402 & 407 & 4 \\
\hline Day & \multicolumn{3}{|c|}{ Whey } & Average & St Dev \\
\hline 0 & & 172 & & 172 & \\
\hline 15 & 1638 & 1389 & 1160 & 1396 & 239 \\
\hline 27 & 1143 & 1425 & 1190 & 1253 & 151 \\
\hline Day & \multicolumn{3}{|c|}{$\mathrm{Na}$ Lactate } & Average & St Dev \\
\hline 0 & & 2935 & & 2935 & \\
\hline 15 & 3030 & 2890 & 3060 & 2993 & 91 \\
\hline 27 & 3040 & 2914 & 3060 & 3005 & 79 \\
\hline Day & \multicolumn{3}{|c|}{ Lactose 50 g soil } & Average & St Dev \\
\hline 0 & & 160 & & 160 & \\
\hline 15 & 1910 & 1973 & 1970 & 1951 & 36 \\
\hline 27 & 2106 & 2109 & 2157 & 2124 & 29 \\
\hline Day & \multicolumn{3}{|c|}{ Autoclaved Control } & Average & St Dev \\
\hline 0 & & 377 & & 377 & \\
\hline 15 & 349 & 369 & 365 & 361 & 11 \\
\hline 27 & & 340 & 375 & 371 & 25 \\
\hline Day & \multicolumn{3}{|c|}{ Control 50 g soil } & Average & St Dev \\
\hline 0 & & 417 & & 417 & \\
\hline 15 & 374 & 372 & 371 & 372 & 2 \\
\hline 27 & 355 & 345 & 348 & 349 & 5 \\
\hline
\end{tabular}


Table 23. Amendment costs.

\begin{tabular}{|l|l|l|l|}
\hline Amendment & Quantity/container & Cost & units \\
\hline sodium acetate & $50 \mathrm{lb}$ bag & 1.63 & $\$ / \mathrm{lb}$ \\
\hline JWR lactate concentrate & $606 \mathrm{lb}$ drum & 1.20 & $\$ / \mathrm{lb}$ \\
\hline molasses & $645 \mathrm{lb}$ drum & 0.45 & $\$ / \mathrm{lb}$ \\
\hline corn syrup & $646 \mathrm{lb}$ drum & 0.40 & $\$ / \mathrm{lb}$ \\
\hline ethanol & $55 \mathrm{gal}$ drum & 2.50 & $\$ /$ gal \\
\hline benzoic acid & $55 \mathrm{lb}$ bag & 1.642 & $\$ / \mathrm{lb}$ \\
\hline EOS & 55 gal drum & 1400 & $\$ /$ drum \\
\hline lactose & Tanker & none & Transport \\
\hline whey & Tanker & 0.15 & $\$ / \mathrm{lb}$ \\
\hline
\end{tabular}

Table 24. Sources for Key Amendments.

\begin{tabular}{|l|l|l|l|l|}
\hline \multicolumn{1}{|c|}{ Amendment } & \multicolumn{1}{c|}{ Supplier } & \multicolumn{1}{c|}{ Contact } & \multicolumn{1}{c|}{ Phone } & \multicolumn{1}{c|}{ Address } \\
\hline Lactose & Columbia River Processing & Roy Dugan & $541 \cdot 481-3770$ & 79588 Rippee Road \\
\hline Whey & Columbia River Processing & Roy Dugan & $541 \cdot 481-3771$ & 79588 Rippee Road \\
\hline 55 High Fructose Corn Syrup & Malt Products Corp. & Joanne McGuire & $530-677-8282$ & \\
\hline \#677 Blackstrap Molasses & Malt Products Corp. & Joanne McGuire & $530-677-8283$ & \\
\hline Ethanol & Pacific Ethanol (office) & Sheril Pagard & 9164032129 & 400 Capitol Mall \\
\hline Milk Hauler from Boardman & Pacific Ethanol Columbia LLC & no contact yet & $541481-2716$ & 71335 Rail Loop Dr \\
\hline EOS & LTI, Inc (Milky Way) & Brad Williamson & 8003276255 & 8631 Depot Road \\
\hline & EOS Remediation & Anne Borden & 919.873 .2204 ext 111 & 1101 Nowell Road \\
\hline & EOS Remediation & Timothy Parker & 919.873 .2204 ext 173 & \\
\hline
\end{tabular}




\section{Recommendations}

Our experiments suggest that TNT removal is relatively easy to stimulate. However, RDX removal is more difficult; therefore, it is best to focus on the product that is the most efficient at removing RDX when selecting the best amendment. Based on our results, five amendments stand out for their ability to remove RDX:

- Molasses

- Corn syrup

- EOS

- Lactose

- Whey

Lactose and whey are both dairy by-products. The lactose product is, essentially, the filtered product of whey. As such, it has much lower solid materials than whey. The particulate material in the whey may cause clogging issues during injection. Furthermore, lactose is available for only the shipping costs. Therefore, lactose was chosen as the substrate to test for the push-pull test.

We also compared corn syrup, molasses, and EOS. All performed well in our testing, but EOS has the advantage of being a longer-lasting material. Although the ethanol treatment was not particularly effective in these studies, discussions among members of the Umatilla Bioremediation Team led to the conclusion that ethanol does have key advantages. In particular, it is quite stable and therefore could be employed in automatic injection systems with minimal threat of degradation over time. In addition, ethanol is known to be effective at reducing well clogging. The study found some evidence of a delayed degradation for ethanol; other studies have found that ethanol can be an effective co-substrate. Thus it was concluded that ethanol should be studied in the push-pull test.

This report should be cited as follows:

Medina, V.F., H. Knotek-Smith, D. Gent, and A. Morrow. 2010. The results of a laboratory feasibility study for the biological treatment of Umatilla Groundwater. ERDC/EL TR-11-xx. Vicksburg, MS: U.S. Army Engineer Research and Development Center. 


\section{References}

Adrian, N. R., C. M. Arnett, and R. F. Hickey. 2003. Stimulating the anaerobic biodegradation of explosives by the addition of hydrogen or electron donors that produce hydrogen. Water Research 37:3499-3507.

Adrian, N. R., and C. M. Arnett. 2007. Anaerobic biotransformation of explosives in aquifer slurries amended with ethanol and propylene glycol. Chemosphere 66:1849-1856.

American Society of Testing and Materials (ASTM). 2007. Oxidation-reduction potential of water. Method D1498-oo.

Bednar, A. J., V. F.Medina, D. S.Ulmer-Scholle, B. A.Frey, B. L.Johnson, W. N.Brostoff, and S. L.Larson. 2007. Effects of organic matter on the distribution of uranium in soil and plant matrices. Chemosphere 70:237-247.

Boopathy, R., J. Manning, and C. F. Kulpa. 1998. A Laboratory Study of the Bioremediation of 2,4,6-Trinitrotoluene-Contaminated Soil Using Aerobic/Anoxic Soil Slurry Reactor. Water Environment Research 70:80-86.

Boopathy, R., and J. F. Manning. 1999. Surfactant-Enhanced Bioremediation of Soil Contaminated with 2,4,6-Trinitrotoluene (TNT) in Soil Slurry Reactors. Water Environment Research 71:119-124.

Boopathy, R., and J. F. Manning. 2000. Laboratory Treatability Study on Hexahydro1,3,5-Trinitro-1,3,5-Triazine-(RDX-) Contaminated Soil from the Iowa Army Ammunition Plant, Burlington, Iowa. Water Environment Research 72:238-242.

Crawford, R. L. 2002. Overview: Biotransformation and Biodegradation. In Manual of Environmental Microbiology. ed. C. J. Hurst, R. L. Crawford, M. J. McInerney, and L. D. Stetzenbach, 901-902. Washington DC: American Society for Microbiology.

Eweis, J. B., S. J. Ergas, D. P. Y. Chang, and E. D. Schroeder. 1998. Microbial Ecology. In Bioremediation Principles. ed. E. Munson, 66-93 Boston, MA: McGraw Hill.

Hoferkamp, L. A., and E. J. Weber. 2006. Nitroaromatic Reduction Kinetics as a Function of Dominant Terminal Electron Acceptor Processes in Natural Sediments. Environmental Science \& Technology. 40:2206-2212.

Krumholz, L. R., J. Li, W. W. Clarkson, G. G. Wilber, and J. M. Suflita. 1997. Transformations of TNT and Related Aminotoluenes in Groundwater Aquifer Slurries Under Different Electron-Accepting Conditions. Journal of Industrial Microbiology \& Biotechnology 18:161-169.

Sagi-Ben Moshe, S., Z. Ronen, O. Dahan, N. Weisbrod, L. Groisman, E. Adar, and R. Nativ. 2009. Sequential biodegradation of TNT, RDX and HMX in a mixture. Environmental Pollution 157:2231-2238. 
Schaefer, C. E., M. E. Fuller, C. W. Condee, J. M. Lowey, and P. B. Hatzinger. 2007. Comparison of biotic and abiotic treatment approaches for co-mingled perchlorate, nitrate, and nitramine explosives in groundwater. Journal of Contaminant Hydrology. 89:231-250.

Stroo, H. F., and R. D. Norris. 2008. Alternatives for In Situ Bioremediation of Perchlorate. In In Situ Bioremediation of Perchlorate in Groundwater, ed. H. F. Stroo and C.Ward, Springer Science LLC.

U.S. Army Corps of Engineers. 2010. Third five year review report for the Umatilla Chemical Depot, Hermiston, Hermiston and Morrow Counties, Oregon. Seattle, WA: Seattle District.

U.S. Environmental Protection Agency (EPA). 1982a. Method 120.1. Conductance. Available on line: http://www.epa.gov/waterscience/methods/method/files/120_1.pdf.

U.S. Environmental Protection Agency (EPA). 1982b. Method 150.2. pH continuous monitoring (electrometric). Available on line: http://www.epa.gov/waterscience/methods/method/files/150_2.pdf.

U.S. Environmental Protection Agency (EPA). 1993. Method 300. Determination of inorganic ions by ion chromatography. Available on line: http://www.epa.gov/waterscience/methods/method/files/300_0.pdf.

U.S. Environmental Protection Agency (EPA). 1994. Method 200.7. Revision 4.4. Determination of metals and trace elements by inductively coupled plasmaatomic Emission spectrophotmetry. Available on line: http://www.epa.gov/waterscience/methods/method/files/200_7.pdf.

U.S. Environmental Protection Agency (EPA). 2004. Method 906oA. Total Organic Carbons. EPA SW 846. Available on line: http://www.caslab.com/EPAMethods/PDF/EPA-Method-9060A.pdf.

U.S. Environmental Protection Agency (EPA). 2006. Method 8330B. Nitroaromatics, nitramines, and nitrate esters by high pressure liquid chromatography. EPA SW 846. Available on line: http://www.epa.gov/epawaste/hazard/testmethods/pdfs/8330b.pdf.

Vance, D. B. 1996. Redox Reactions in Remediation. Environmental Technology 6(4):2425. Available online at: http://2the4.net/redox.htm.

Waisner, S., L. Hansen, H. Fredrickson, C. Nestler, M. Zappi, S. Banerji, and R. Bajpai. 2002. Biodegradation of RDX within soil-water slurries using a combination of differing redox incubation conditions. Journal of Hazardous Materials 95:91106.

Wani, A. H., and J. Davis. 2003. RDX biodegradation column study: influence of ubiquitous electron acceptors on anaerobic biotransformation of RDX. Journal of Chemical Technology and Biotechnology 78:1082-1092. 


\section{Appendix A: Raw Explosive Analysis Data}

Table A1. Run 1 TNT Raw Data.

\begin{tabular}{|c|c|c|c|c|c|c|c|c|c|}
\hline TNT & 24-Feb-10 & 25-Feb-10 & 26-Feb-10 & 1-Mar-10 & 4-Mar-10 & 8-Mar-10 & 11-Mar-10 & 16-Mar-10 & 23-Mar-10 \\
\hline 1 & 1.050 & 0.785 & 0.550 & 0.248 & 0.155 & 0.000 & 0.000 & 0.000 & 0.000 \\
\hline 2 & 1.010 & 0.777 & 0.538 & 0.237 & 0.154 & 0.000 & 0.000 & 0.000 & 0.000 \\
\hline 3 & 1.000 & 0.875 & 0.704 & 0.241 & 0.136 & 0.000 & 0.000 & 0.000 & 0.000 \\
\hline TNT Control & 1.020 & 0.812 & 0.597 & 0.242 & 0.148 & 0.000 & 0.000 & 0.000 & 0.000 \\
\hline St Dev & 0.022 & 0.044 & 0.076 & 0.005 & 0.009 & 0.000 & 0.000 & 0.000 & 0.000 \\
\hline 4 & 1.000 & 0.679 & 0.426 & 0.000 & 0.000 & 0.000 & 0.000 & 0.000 & 0.000 \\
\hline 5 & 1.030 & 0.708 & 0.445 & 0.000 & 0.000 & 0.000 & 0.000 & 0.000 & 0.000 \\
\hline 6 & 1.060 & 0.709 & 0.540 & 0.000 & 0.000 & 0.000 & 0.000 & 0.000 & 0.000 \\
\hline TNT Corn Syrup & 1.030 & 0.699 & 0.470 & 0.000 & 0.000 & 0.000 & 0.000 & 0.000 & 0.000 \\
\hline St Dev & 0.024 & 0.014 & 0.050 & 0.000 & 0.000 & 0.000 & 0.000 & 0.000 & 0.000 \\
\hline 7 & 1.050 & 0.493 & 0.000 & 0.000 & 0.000 & 0.000 & 0.000 & 0.000 & 0.000 \\
\hline 8 & 1.030 & 0.447 & 0.000 & 0.000 & 0.000 & 0.000 & 0.000 & 0.000 & 0.000 \\
\hline 9 & 1.030 & 0.420 & 0.000 & 0.000 & 0.000 & 0.000 & 0.000 & 0.000 & 0.000 \\
\hline TNT Molasses & 1.037 & 0.453 & 0.000 & 0.000 & 0.000 & 0.000 & 0.000 & 0.000 & 0.000 \\
\hline St Dev & 0.009 & 0.030 & 0.000 & 0.000 & 0.000 & 0.000 & 0.000 & 0.000 & 0.000 \\
\hline 10 & 1.060 & 0.176 & 0.000 & 0.000 & 0.000 & 0.000 & 0.000 & 0.000 & 0.000 \\
\hline 11 & 1.080 & 0.149 & 0.000 & 0.000 & 0.000 & 0.000 & 0.000 & 0.000 & 0.000 \\
\hline 12 & 1.080 & 0.167 & 0.000 & 0.000 & 0.000 & 0.000 & 0.000 & 0.000 & 0.000 \\
\hline TNT Lactose & 1.073 & 0.164 & 0.000 & 0.000 & 0.000 & 0.000 & 0.000 & 0.000 & 0.000 \\
\hline St Dev & 0.009 & 0.011 & 0.000 & 0.000 & 0.000 & 0.000 & 0.000 & 0.000 & 0.000 \\
\hline 13 & 0.602 & 0.412 & 0.204 & 0.000 & 0.000 & 0.000 & 0.000 & 0.000 & 0.000 \\
\hline 14 & 0.552 & 0.386 & 0.174 & 0.000 & 0.000 & 0.000 & 0.000 & 0.000 & 0.000 \\
\hline 15 & 0.553 & 0.397 & 0.000 & 0.000 & 0.000 & 0.000 & 0.000 & 0.000 & 0.000 \\
\hline TNT EOS & 0.569 & 0.398 & 0.126 & 0.000 & 0.000 & 0.000 & 0.000 & 0.000 & 0.000 \\
\hline St Dev & 0.023 & 0.011 & 0.090 & 0.000 & 0.000 & 0.000 & 0.000 & 0.000 & 0.000 \\
\hline 16 & 1.100 & 0.781 & 0.581 & 0.259 & 0.146 & 0.000 & 0.000 & 0.000 & 0.000 \\
\hline 17 & 1.130 & 0.801 & 0.579 & 0.211 & 0.000 & 0.000 & 0.000 & 0.000 & 0.000 \\
\hline 18 & 1.060 & 0.727 & 0.520 & 0.195 & 0.000 & 0.000 & 0.000 & 0.000 & 0.000 \\
\hline TNT Acetate & 1.097 & 0.770 & 0.560 & 0.222 & 0.049 & 0.000 & 0.000 & 0.000 & 0.000 \\
\hline St Dev & 0.029 & 0.031 & 0.028 & 0.027 & 0.069 & 0.000 & 0.000 & 0.000 & 0.000 \\
\hline
\end{tabular}


Table A2. Run 14 Amino 2,6-dinitroltoluene Raw Data.

\begin{tabular}{|c|c|c|c|c|c|c|c|c|c|}
\hline & 24-Feb-10 & 25-Feb-10 & 26-Feb-10 & 1-Mar-10 & 4-Mar-10 & 8-Mar-10 & 11-Mar-10 & 16-Mar-10 & 23-Mar-10 \\
\hline 1 & 0.000 & 0.000 & 0.027 & 0.098 & 0.115 & 0.136 & 0.117 & 0.000 & 0.000 \\
\hline 2 & 0.000 & 0.000 & 0.035 & 0.103 & 0.118 & 0.138 & 0.131 & 0.078 & 0.003 \\
\hline 3 & 0.000 & 0.000 & 0.052 & 0.089 & 0.124 & 0.143 & 0.086 & 0.000 & 0.000 \\
\hline $\begin{array}{l}\text { 4-A-2,6-D } \\
\text { Control }\end{array}$ & 0.000 & 0.000 & 0.038 & 0.097 & 0.119 & 0.139 & 0.111 & 0.026 & 0.001 \\
\hline St Dev & 0.000 & 0.000 & 0.010 & 0.006 & 0.004 & 0.003 & 0.019 & 0.037 & 0.001 \\
\hline 4 & 0.000 & 0.025 & 0.075 & 0.000 & 0.000 & 0.000 & 0.000 & 0.000 & 0.000 \\
\hline 5 & 0.000 & 0.018 & 0.054 & 0.000 & 0.000 & 0.000 & 0.000 & 0.000 & 0.000 \\
\hline 6 & 0.000 & 0.022 & 0.085 & 0.117 & 0.000 & 0.000 & 0.000 & 0.000 & 0.000 \\
\hline $\begin{array}{l}\text { 4-A-2,6-D } \\
\text { Corn Syrup }\end{array}$ & 0.000 & 0.022 & 0.071 & 0.039 & 0.000 & 0.000 & 0.000 & 0.000 & 0.000 \\
\hline St Dev & 0.000 & 0.003 & 0.013 & 0.055 & 0.000 & 0.000 & 0.000 & 0.000 & 0.000 \\
\hline 7 & 0.000 & 0.081 & 0.164 & 0.000 & 0.000 & 0.000 & 0.000 & 0.000 & 0.000 \\
\hline 8 & 0.000 & 0.092 & 0.182 & 0.000 & 0.000 & 0.000 & 0.000 & 0.000 & 0.000 \\
\hline 9 & 0.000 & 0.084 & 0.162 & 0.000 & 0.000 & 0.000 & 0.000 & 0.000 & 0.000 \\
\hline $\begin{array}{l}\text { 4-A-2,6-D } \\
\text { Molasses }\end{array}$ & 0.000 & 0.086 & 0.169 & 0.000 & 0.000 & 0.000 & 0.000 & 0.000 & 0.000 \\
\hline St Dev & 0.000 & 0.005 & 0.009 & 0.000 & 0.000 & 0.000 & 0.000 & 0.000 & 0.000 \\
\hline 10 & 0.000 & 0.176 & 0.372 & 0.000 & 0.000 & 0.000 & 0.000 & 0.000 & 0.000 \\
\hline 11 & 0.000 & 0.200 & 0.000 & 0.000 & 0.000 & 0.000 & 0.000 & 0.000 & 0.000 \\
\hline 12 & 0.000 & 0.193 & 0.375 & 0.000 & 0.000 & 0.000 & 0.000 & 0.000 & 0.000 \\
\hline $\begin{array}{l}\text { 4-A-2,6-D } \\
\text { Lactose }\end{array}$ & 0.000 & 0.190 & 0.249 & 0.000 & 0.000 & 0.000 & 0.000 & 0.000 & 0.000 \\
\hline St Dev & 0.000 & 0.010 & 0.176 & 0.000 & 0.000 & 0.000 & 0.000 & 0.000 & 0.000 \\
\hline 13 & 0.000 & 0.000 & 0.000 & 0.000 & 0.000 & 0.000 & 0.000 & 0.000 & 0.000 \\
\hline 14 & 0.000 & 0.000 & 0.000 & 0.000 & 0.000 & 0.000 & 0.000 & 0.000 & 0.000 \\
\hline 15 & 0.000 & 0.000 & 0.024 & 0.000 & 0.000 & 0.000 & 0.000 & 0.000 & 0.000 \\
\hline 4-A-2,6-D EOS & 0.000 & 0.000 & 0.008 & 0.000 & 0.000 & 0.000 & 0.000 & 0.000 & 0.000 \\
\hline St Dev & 0.000 & 0.000 & 0.011 & 0.000 & 0.000 & 0.000 & 0.000 & 0.000 & 0.000 \\
\hline 16 & 0.000 & 0.000 & 0.040 & 0.000 & 0.126 & 0.143 & 0.107 & 0.000 & 0.000 \\
\hline 17 & 0.000 & 0.000 & 0.041 & 0.000 & 0.136 & 0.146 & 0.129 & 0.037 & 0.000 \\
\hline 18 & 0.000 & 0.000 & 0.049 & 0.000 & 0.140 & 0.143 & 0.109 & 0.044 & 0.000 \\
\hline $\begin{array}{l}\text { 4-A-2,6-D } \\
\text { Acetate }\end{array}$ & 0.000 & 0.000 & 0.043 & 0.000 & 0.134 & 0.144 & 0.115 & 0.027 & 0.000 \\
\hline St Dev & 0.000 & 0.000 & 0.004 & 0.000 & 0.006 & 0.001 & 0.010 & 0.019 & 0.000 \\
\hline
\end{tabular}


Table A3. Run 12 Amino 4,6 dinitrotoluene Raw Data.

\begin{tabular}{|c|c|c|c|c|c|c|c|c|c|}
\hline & 24-Feb-10 & 25-Feb-10 & 26-Feb-10 & 1-Mar-10 & 4-Mar-10 & 8-Mar-10 & 11-Mar-10 & 16-Mar-10 & 23-Mar-10 \\
\hline 1 & 0.000 & 0.000 & 0.016 & 0.034 & 0.037 & 0.029 & 0.000 & 0.000 & 0.000 \\
\hline 2 & 0.000 & 0.000 & 0.018 & 0.032 & 0.045 & 0.048 & 0.030 & 0.000 & 0.000 \\
\hline 3 & 0.000 & 0.000 & 0.025 & 0.030 & 0.042 & 0.028 & 0.000 & 0.000 & 0.000 \\
\hline $\begin{array}{l}\text { 2-A-4,6-D } \\
\text { Control }\end{array}$ & 0.000 & 0.000 & 0.020 & 0.032 & 0.041 & 0.035 & 0.010 & 0.000 & 0.000 \\
\hline St Dev & 0.000 & 0.000 & 0.004 & 0.002 & 0.003 & 0.009 & 0.014 & 0.000 & 0.000 \\
\hline 4 & 0.000 & 0.000 & 0.022 & 0.000 & 0.000 & 0.000 & 0.000 & 0.000 & 0.000 \\
\hline 5 & 0.000 & 0.000 & 0.011 & 0.000 & 0.000 & 0.000 & 0.000 & 0.000 & 0.000 \\
\hline 6 & 0.000 & 0.000 & 0.026 & 0.000 & 0.000 & 0.000 & 0.000 & 0.000 & 0.000 \\
\hline $\begin{array}{l}\text { 2-A-4,6-D } \\
\text { Corn Syrup }\end{array}$ & 0.000 & 0.000 & 0.020 & 0.000 & 0.000 & 0.000 & 0.000 & 0.000 & 0.000 \\
\hline St Dev & 0.000 & 0.000 & 0.006 & 0.000 & 0.000 & 0.000 & 0.000 & 0.000 & 0.000 \\
\hline 7 & 0.000 & 0.000 & 0.037 & 0.000 & 0.000 & 0.000 & 0.000 & 0.000 & 0.000 \\
\hline 8 & 0.000 & 0.000 & 0.049 & 0.000 & 0.000 & 0.000 & 0.000 & 0.000 & 0.000 \\
\hline 9 & 0.000 & 0.010 & 0.051 & 0.000 & 0.000 & 0.000 & 0.000 & 0.000 & 0.000 \\
\hline $\begin{array}{l}\text { 2-A-4,6-D } \\
\text { Molasses }\end{array}$ & 0.000 & 0.003 & 0.046 & 0.000 & 0.000 & 0.000 & 0.000 & 0.000 & 0.000 \\
\hline St Dev & 0.000 & 0.005 & 0.006 & 0.000 & 0.000 & 0.000 & 0.000 & 0.000 & 0.000 \\
\hline 10 & 0.000 & 0.000 & 0.000 & 0.000 & 0.000 & 0.000 & 0.000 & 0.000 & 0.000 \\
\hline 11 & 0.000 & 0.000 & 0.000 & 0.000 & 0.000 & 0.000 & 0.000 & 0.000 & 0.000 \\
\hline 12 & 0.000 & 0.000 & 0.000 & 0.000 & 0.000 & 0.000 & 0.000 & 0.000 & 0.000 \\
\hline $\begin{array}{l}\text { 2-A-4,6-D } \\
\text { Lactose }\end{array}$ & 0.000 & 0.000 & 0.000 & 0.000 & 0.000 & 0.000 & 0.000 & 0.000 & 0.000 \\
\hline St Dev & 0.000 & 0.000 & 0.000 & 0.000 & 0.000 & 0.000 & 0.000 & 0.000 & 0.000 \\
\hline 13 & 0.000 & 0.000 & 0.204 & 0.000 & 0.000 & 0.000 & 0.000 & 0.000 & 0.000 \\
\hline 14 & 0.000 & 0.000 & 0.000 & 0.000 & 0.000 & 0.000 & 0.000 & 0.000 & 0.000 \\
\hline 15 & 0.000 & 0.000 & 0.000 & 0.000 & 0.000 & 0.000 & 0.000 & 0.000 & 0.000 \\
\hline $\begin{array}{l}2-A-4,6-D \\
\text { EOS }\end{array}$ & 0.000 & 0.000 & 0.068 & 0.000 & 0.000 & 0.000 & 0.000 & 0.000 & 0.000 \\
\hline St Dev & 0.000 & 0.000 & 0.096 & 0.000 & 0.000 & 0.000 & 0.000 & 0.000 & 0.000 \\
\hline 16 & 0.000 & 0.000 & 0.019 & 0.062 & 0.044 & 0.030 & 0.000 & 0.000 & 0.000 \\
\hline 17 & 0.000 & 0.000 & 0.019 & 0.070 & 0.038 & 0.015 & 0.000 & 0.000 & 0.000 \\
\hline 18 & 0.000 & 0.000 & 0.018 & 0.065 & 0.052 & 0.181 & 0.000 & 0.000 & 0.000 \\
\hline $\begin{array}{l}\text { 2-A-4,6-D } \\
\text { Acetate }\end{array}$ & 0.000 & 0.000 & 0.019 & 0.066 & 0.045 & 0.075 & 0.000 & 0.000 & 0.000 \\
\hline St Dev & 0.000 & 0.000 & 0.000 & 0.003 & 0.006 & 0.075 & 0.000 & 0.000 & 0.000 \\
\hline
\end{tabular}


Table A4. Run 1 HMX Raw Data.

\begin{tabular}{|c|c|c|c|c|c|c|c|c|c|}
\hline HMX & 24-Feb-10 & 25-Feb-10 & 26-Feb-10 & 1-Mar-10 & 4-Mar-10 & 8-Mar-10 & 11-Mar-10 & 16-Mar-10 & 23-Mar-10 \\
\hline 1 & 0.671 & 0.950 & 1.200 & 1.550 & 1.530 & 1.730 & 1.790 & 1.430 & 1.450 \\
\hline 2 & 0.636 & 0.919 & 1.100 & 1.510 & 1.540 & 1.650 & 1.740 & 1.590 & 1.460 \\
\hline 3 & 0.678 & 1.040 & 1.310 & 1.470 & 1.480 & 1.620 & 1.670 & 1.270 & 1.330 \\
\hline HMX Control & 0.662 & 0.970 & 1.203 & 1.510 & 1.517 & 1.667 & 1.733 & 1.430 & 1.413 \\
\hline St Dev & 0.018 & 0.051 & 0.086 & 0.033 & 0.026 & 0.046 & 0.049 & 0.131 & 0.059 \\
\hline 4 & 0.592 & 0.841 & 0.743 & 1.480 & 1.440 & 0.998 & 0.727 & 0.056 & 0.092 \\
\hline 5 & 0.610 & 0.852 & 0.837 & 1.520 & 1.350 & 0.829 & 0.469 & 0.225 & 0.000 \\
\hline 6 & 0.685 & 0.879 & 1.010 & 1.490 & 1.150 & 1.200 & 1.300 & 0.750 & 0.000 \\
\hline $\begin{array}{l}\text { HMX Corn } \\
\text { Syrup }\end{array}$ & 0.629 & 0.857 & 0.863 & 1.497 & 1.313 & 1.009 & 0.832 & 0.344 & 0.031 \\
\hline St Dev & 0.040 & 0.016 & 0.111 & 0.017 & 0.121 & 0.152 & 0.347 & 0.295 & 0.043 \\
\hline 7 & 0.411 & 0.839 & 1.180 & 1.510 & 1.380 & 1.140 & 0.904 & 0.343 & 0.000 \\
\hline 8 & 0.396 & 0.837 & 1.310 & 1.650 & 1.630 & 1.350 & 1.110 & 0.404 & 0.000 \\
\hline 9 & 0.447 & 0.776 & 0.950 & 1.480 & 1.360 & 1.180 & 1.080 & 0.364 & 0.000 \\
\hline $\begin{array}{l}\text { HMX } \\
\text { Molasses }\end{array}$ & 0.418 & 0.817 & 1.147 & 1.547 & 1.457 & 1.223 & 1.031 & 0.370 & 0.000 \\
\hline St Dev & 0.021 & 0.029 & 0.149 & 0.074 & 0.123 & 0.091 & 0.091 & 0.025 & 0.000 \\
\hline 10 & 0.426 & 0.980 & 1.500 & 1.670 & 1.460 & 1.330 & 1.330 & 1.300 & 1.090 \\
\hline 11 & 0.390 & 0.820 & 1.370 & 1.180 & 1.220 & 1.140 & 1.120 & 0.687 & 0.376 \\
\hline 12 & 0.397 & 0.962 & 1.490 & 1.620 & 1.090 & 1.090 & 1.100 & 0.908 & 0.873 \\
\hline HMX Lactose & 0.404 & 0.921 & 1.453 & 1.490 & 1.257 & 1.187 & 1.183 & 0.965 & 0.780 \\
\hline St Dev & 0.016 & 0.072 & 0.059 & 0.220 & 0.153 & 0.103 & 0.104 & 0.253 & 0.299 \\
\hline 13 & 0.360 & 0.722 & 1.280 & 1.350 & 1.420 & 1.310 & 1.140 & 0.803 & 0.708 \\
\hline 14 & 0.382 & 0.678 & 1.150 & 1.290 & 1.210 & 1.200 & 1.130 & 0.764 & 0.584 \\
\hline 15 & 0.046 & 0.796 & 1.260 & 1.360 & 1.300 & 1.300 & 1.230 & 0.838 & 0.744 \\
\hline HMX EOS & 0.263 & 0.732 & 1.230 & 1.333 & 1.310 & 1.270 & 1.167 & 0.802 & 0.679 \\
\hline St Dev & 0.153 & 0.049 & 0.057 & 0.031 & 0.086 & 0.050 & 0.045 & 0.030 & 0.069 \\
\hline 16 & 0.424 & 0.868 & 1.300 & 1.530 & 1.600 & 1.700 & 1.910 & 1.370 & 1.390 \\
\hline 17 & 0.441 & 0.960 & 1.430 & 1.670 & 1.720 & 1.890 & 1.930 & 1.660 & 1.490 \\
\hline 18 & 0.401 & 0.804 & 1.190 & 1.340 & 1.370 & 1.490 & 1.530 & 1.110 & 1.200 \\
\hline HMX Acetate & 0.422 & 0.877 & 1.307 & 1.513 & 1.563 & 1.693 & 1.790 & 1.380 & 1.360 \\
\hline St Dev & 0.016 & 0.064 & 0.098 & 0.135 & 0.145 & 0.163 & 0.184 & 0.225 & 0.120 \\
\hline
\end{tabular}


Table A5. Run 1 RDX Raw Data.

\begin{tabular}{|c|c|c|c|c|c|c|c|c|c|}
\hline RDX & 24-Feb-10 & 25-Feb-10 & 26-Feb-10 & 1-Mar-10 & 4-Mar-10 & 8-Mar-10 & 11-Mar-10 & 16-Mar-10 & 23-Mar-10 \\
\hline 1 & 0.787 & 0.786 & 0.808 & 0.819 & 0.743 & 0.760 & 0.740 & 0.588 & 0.554 \\
\hline 2 & 0.742 & 0.768 & 0.784 & 0.784 & 0.749 & 0.759 & 0.769 & 0.679 & 0.612 \\
\hline 3 & 0.733 & 0.867 & 1.140 & 0.766 & 0.726 & 0.718 & 0.704 & 0.482 & 0.511 \\
\hline RDX Control & 0.754 & 0.807 & 0.911 & 0.790 & 0.739 & 0.746 & 0.738 & 0.583 & 0.559 \\
\hline St Dev & 0.024 & 0.043 & 0.162 & 0.022 & 0.010 & 0.020 & 0.027 & 0.081 & 0.041 \\
\hline 4 & 0.757 & 0.767 & 0.808 & 0.093 & 0.000 & 0.000 & 0.000 & 0.000 & 0.000 \\
\hline 5 & 0.776 & 0.774 & 0.775 & 0.078 & 0.000 & 0.000 & 0.000 & 0.000 & 0.000 \\
\hline 6 & 0.804 & 0.780 & 0.998 & 0.723 & 0.437 & 0.133 & 0.000 & 0.000 & 0.000 \\
\hline $\begin{array}{l}\text { RDX Corn } \\
\text { Syrup }\end{array}$ & 0.779 & 0.774 & 0.860 & 0.298 & 0.146 & 0.044 & 0.000 & 0.000 & 0.000 \\
\hline St Dev & 0.019 & 0.005 & 0.098 & 0.301 & 0.206 & 0.063 & 0.000 & 0.000 & 0.000 \\
\hline 7 & 0.765 & 0.737 & 0.690 & 0.529 & 0.000 & 0.000 & 0.000 & 0.000 & 0.000 \\
\hline 8 & 0.754 & 0.778 & 0.754 & 0.482 & 0.067 & 0.000 & 0.000 & 0.000 & 0.000 \\
\hline 9 & 0.774 & 0.735 & 0.653 & 0.463 & 0.000 & 0.000 & 0.000 & 0.000 & 0.000 \\
\hline $\begin{array}{l}\text { RDX } \\
\text { Molasses }\end{array}$ & 0.764 & 0.750 & 0.699 & 0.491 & 0.022 & 0.000 & 0.000 & 0.000 & 0.000 \\
\hline St Dev & 0.008 & 0.020 & 0.042 & 0.028 & 0.032 & 0.000 & 0.000 & 0.000 & 0.000 \\
\hline 10 & 0.756 & 0.732 & 0.678 & 0.227 & 0.000 & 0.000 & 0.000 & 0.000 & 0.000 \\
\hline 11 & 0.752 & 0.678 & 0.654 & 0.000 & 0.000 & 0.000 & 0.000 & 0.000 & 0.000 \\
\hline 12 & 0.763 & 0.726 & 0.662 & 0.025 & 0.000 & 0.000 & 0.000 & 0.000 & 0.000 \\
\hline RDX Lactose & 0.757 & 0.712 & 0.665 & 0.084 & 0.000 & 0.000 & 0.000 & 0.000 & 0.000 \\
\hline St Dev & 0.005 & 0.024 & 0.010 & 0.102 & 0.000 & 0.000 & 0.000 & 0.000 & 0.000 \\
\hline 13 & 0.717 & 0.762 & 0.747 & 0.000 & 0.000 & 0.000 & 0.000 & 0.000 & 0.000 \\
\hline 14 & 0.751 & 0.742 & 0.758 & 0.000 & 0.000 & 0.000 & 0.000 & 0.000 & 0.000 \\
\hline 15 & 0.741 & 0.744 & 0.759 & 0.000 & 0.000 & 0.000 & 0.000 & 0.000 & 0.000 \\
\hline RDX EOS & 0.736 & 0.749 & 0.755 & 0.000 & 0.000 & 0.000 & 0.000 & 0.000 & 0.000 \\
\hline St Dev & 0.014 & 0.009 & 0.005 & 0.000 & 0.000 & 0.000 & 0.000 & 0.000 & 0.000 \\
\hline 16 & 0.773 & 0.752 & 0.784 & 0.792 & 0.785 & 0.756 & 0.752 & 0.645 & 0.518 \\
\hline 17 & 0.788 & 0.782 & 0.804 & 0.804 & 0.782 & 0.764 & 0.761 & 0.727 & 0.538 \\
\hline 18 & 0.776 & 0.761 & 0.778 & 0.772 & 0.753 & 0.721 & 0.708 & 0.585 & 0.500 \\
\hline RDX Acetate & 0.779 & 0.765 & 0.789 & 0.789 & 0.773 & 0.747 & 0.740 & 0.652 & 0.519 \\
\hline St Dev & 0.006 & 0.013 & 0.011 & 0.013 & 0.014 & 0.019 & 0.023 & 0.058 & 0.016 \\
\hline
\end{tabular}


Table A6. Run 1 MNX Raw Data.

\begin{tabular}{|c|c|c|c|c|c|c|c|c|c|}
\hline MNX & 24-Feb-10 & 25-Feb-10 & 26-Feb-10 & 1-Mar-10 & 4-Mar-10 & 8-Mar-10 & 11-Mar-10 & 16-Mar-10 & 23-Mar-10 \\
\hline 1 & 0.000 & 0.000 & 0.103 & 0.000 & 0.000 & 0.067 & 0.000 & 0.020 & 0.037 \\
\hline 2 & 0.000 & 0.000 & 0.109 & 0.000 & 0.000 & 0.000 & 0.000 & 0.015 & 0.032 \\
\hline 3 & 0.000 & 0.000 & 0.135 & 0.000 & 0.000 & 0.000 & 0.000 & 0.019 & 0.031 \\
\hline MNX Control & 0.000 & 0.000 & 0.116 & 0.000 & 0.000 & 0.022 & 0.000 & 0.018 & 0.033 \\
\hline St Dev & 0.000 & 0.000 & 0.014 & 0.000 & 0.000 & 0.032 & 0.000 & 0.002 & 0.003 \\
\hline 4 & 0.000 & 0.000 & 0.087 & 0.407 & 0.110 & 0.066 & 0.000 & 0.000 & 0.000 \\
\hline 5 & 0.000 & 0.000 & 0.082 & 0.403 & 0.136 & 0.071 & 0.000 & 0.000 & 0.000 \\
\hline 6 & 0.000 & 0.000 & 0.087 & 0.105 & 0.000 & 0.122 & 0.000 & 0.000 & 0.000 \\
\hline $\begin{array}{l}\text { MNX Corn } \\
\text { Syrup }\end{array}$ & 0.000 & 0.000 & 0.085 & 0.305 & 0.082 & 0.086 & 0.000 & 0.000 & 0.000 \\
\hline St Dev & 0.000 & 0.000 & 0.002 & 0.141 & 0.059 & 0.025 & 0.000 & 0.000 & 0.000 \\
\hline 7 & 0.000 & 0.000 & 0.000 & 0.103 & 0.157 & 0.066 & 0.000 & 0.000 & 0.000 \\
\hline 8 & 0.000 & 0.000 & 0.000 & 0.104 & 0.000 & 0.079 & 0.000 & 0.000 & 0.000 \\
\hline 9 & 0.000 & 0.000 & 0.000 & 0.105 & 0.156 & 0.082 & 0.000 & 0.000 & 0.000 \\
\hline $\begin{array}{l}\text { MNX } \\
\text { Molasses }\end{array}$ & 0.000 & 0.000 & 0.000 & 0.104 & 0.104 & 0.076 & 0.000 & 0.000 & 0.000 \\
\hline St Dev & 0.000 & 0.000 & 0.000 & 0.001 & 0.074 & 0.007 & 0.000 & 0.000 & 0.000 \\
\hline 10 & 0.000 & 0.000 & 0.000 & 0.248 & 0.124 & 0.083 & 0.000 & 0.095 & 0.000 \\
\hline 11 & 0.000 & 0.000 & 0.000 & 0.105 & 0.077 & 0.000 & 0.000 & 0.000 & 0.000 \\
\hline 12 & 0.000 & 0.000 & 0.000 & 0.279 & 0.000 & 0.000 & 0.000 & 0.000 & 0.000 \\
\hline $\begin{array}{l}\text { MNX } \\
\text { Lactose }\end{array}$ & 0.000 & 0.000 & 0.000 & 0.211 & 0.067 & 0.028 & 0.000 & 0.032 & 0.000 \\
\hline St Dev & 0.000 & 0.000 & 0.000 & 0.076 & 0.051 & 0.039 & 0.000 & 0.045 & 0.000 \\
\hline 13 & 0.000 & 0.000 & 0.000 & 0.111 & 0.093 & 0.077 & 0.000 & 0.000 & 0.000 \\
\hline 14 & 0.000 & 0.000 & 0.000 & 0.087 & 0.000 & 0.103 & 0.095 & 0.000 & 0.000 \\
\hline 15 & 0.000 & 0.000 & 0.000 & 0.103 & 0.095 & 0.076 & 0.000 & 0.000 & 0.000 \\
\hline MNXEOS & 0.000 & 0.000 & 0.000 & 0.100 & 0.063 & 0.085 & 0.032 & 0.000 & 0.000 \\
\hline St Dev & 0.000 & 0.000 & 0.000 & 0.010 & 0.044 & 0.012 & 0.045 & 0.000 & 0.000 \\
\hline 16 & 0.000 & 0.000 & 0.000 & 0.000 & 0.000 & 0.000 & 0.000 & 0.018 & 0.035 \\
\hline 17 & 0.000 & 0.000 & 0.000 & 0.000 & 0.000 & 0.000 & 0.000 & 0.020 & 0.032 \\
\hline 18 & 0.000 & 0.000 & 0.000 & 0.000 & 0.000 & 0.000 & 0.000 & 0.026 & 0.048 \\
\hline MNX Acetate & 0.000 & 0.000 & 0.000 & 0.000 & 0.000 & 0.000 & 0.000 & 0.021 & 0.038 \\
\hline St Dev & 0.000 & 0.000 & 0.000 & 0.000 & 0.000 & 0.000 & 0.000 & 0.003 & 0.007 \\
\hline
\end{tabular}


Table A7. Run 1 DNX Raw Data.

\begin{tabular}{|c|c|c|c|c|c|c|c|c|c|}
\hline DNX & 24-Feb-10 & 25-Feb-10 & 26-Feb-10 & 1-Mar-10 & 4-Mar-10 & 8-Mar-10 & 11-Mar-10 & 16-Mar-10 & 23-Mar-10 \\
\hline 1 & 0.000 & 0.000 & 0.000 & 0.000 & 0.000 & 0.000 & 0.000 & 0.000 & 0.000 \\
\hline 2 & 0.000 & 0.000 & 0.000 & 0.000 & 0.000 & 0.000 & 0.000 & 0.000 & 0.000 \\
\hline 3 & 0.000 & 0.000 & 0.000 & 0.000 & 0.000 & 0.000 & 0.000 & 0.000 & 0.000 \\
\hline DNX Control & 0.000 & 0.000 & 0.000 & 0.000 & 0.000 & 0.000 & 0.000 & 0.000 & 0.000 \\
\hline St Dev & 0.000 & 0.000 & 0.000 & 0.000 & 0.000 & 0.000 & 0.000 & 0.000 & 0.000 \\
\hline 4 & 0.000 & 0.000 & 0.000 & 0.195 & 0.260 & 0.169 & 0.000 & 0.000 & 0.000 \\
\hline 5 & 0.000 & 0.000 & 0.000 & 0.198 & 0.000 & 0.099 & 0.073 & 0.000 & 0.000 \\
\hline 6 & 0.000 & 0.000 & 0.000 & 0.000 & 0.000 & 0.000 & 0.104 & 0.019 & 0.000 \\
\hline $\begin{array}{l}\text { DNX Corn } \\
\text { Syrup }\end{array}$ & 0.000 & 0.000 & 0.000 & 0.131 & 0.087 & 0.089 & 0.059 & 0.010 & 0.000 \\
\hline St Dev & 0.000 & 0.000 & 0.000 & 0.093 & 0.123 & 0.069 & 0.044 & 0.010 & 0.000 \\
\hline 7 & 0.000 & 0.000 & 0.000 & 0.000 & 0.156 & 0.093 & 0.000 & 0.000 & 0.000 \\
\hline 8 & 0.000 & 0.000 & 0.000 & 0.000 & 0.109 & 0.101 & 0.073 & 0.000 & 0.000 \\
\hline 9 & 0.000 & 0.000 & 0.000 & 0.000 & 0.142 & 0.091 & 0.070 & 0.000 & 0.000 \\
\hline $\begin{array}{l}\text { DNX } \\
\text { Molasses }\end{array}$ & 0.000 & 0.000 & 0.000 & 0.000 & 0.136 & 0.095 & 0.048 & 0.000 & 0.000 \\
\hline St Dev & 0.000 & 0.000 & 0.000 & 0.000 & 0.020 & 0.004 & 0.034 & 0.000 & 0.000 \\
\hline 10 & 0.000 & 0.000 & 0.000 & & 0.242 & 0.181 & 0.000 & 0.000 & 0.000 \\
\hline 11 & 0.000 & 0.000 & 0.000 & 0.195 & 0.167 & 0.094 & 0.000 & 0.000 & 0.000 \\
\hline 12 & 0.000 & 0.000 & 0.000 & 0.190 & 0.332 & 0.000 & 0.309 & 0.000 & 0.000 \\
\hline DNX Lactose & 0.000 & 0.000 & 0.000 & 0.193 & 0.247 & 0.092 & 0.103 & 0.000 & 0.000 \\
\hline St Dev & 0.000 & 0.000 & 0.000 & 0.003 & 0.067 & 0.074 & 0.146 & 0.000 & 0.000 \\
\hline 13 & 0.000 & 0.000 & 0.000 & 0.250 & 0.200 & 0.129 & 0.083 & 0.000 & 0.000 \\
\hline 14 & 0.000 & 0.000 & 0.000 & 0.179 & 0.134 & 0.101 & 0.084 & 0.000 & 0.000 \\
\hline 15 & 0.000 & 0.000 & 0.000 & 0.214 & 0.175 & 0.118 & 0.086 & 0.000 & 0.000 \\
\hline DNXEOS & 0.000 & 0.000 & 0.000 & 0.214 & 0.170 & 0.116 & 0.084 & 0.000 & 0.000 \\
\hline St Dev & 0.000 & 0.000 & 0.000 & 0.029 & 0.027 & 0.012 & 0.001 & 0.000 & 0.000 \\
\hline 16 & 0.000 & 0.000 & 0.000 & 0.000 & 0.000 & 0.000 & 0.000 & 0.000 & 0.000 \\
\hline 17 & 0.000 & 0.000 & 0.000 & 0.000 & 0.000 & 0.000 & 0.000 & 0.000 & 0.000 \\
\hline 18 & 0.000 & 0.000 & 0.000 & 0.000 & 0.000 & 0.000 & 0.000 & 0.000 & 0.000 \\
\hline DNX Acetate & 0.000 & 0.000 & 0.000 & 0.000 & 0.000 & 0.000 & 0.000 & 0.000 & 0.000 \\
\hline St Dev & 0.000 & 0.000 & 0.000 & 0.000 & 0.000 & 0.000 & 0.000 & 0.000 & 0.000 \\
\hline
\end{tabular}


Table A8. Run 1 TNX Raw Data.

\begin{tabular}{|c|c|c|c|c|c|c|c|c|c|}
\hline TNX & 24-Feb-10 & 25-Feb-10 & 26-Feb-10 & 1-Mar-10 & 4-Mar-10 & 8-Mar-10 & 11-Mar-10 & 16-Mar-10 & 23-Mar-10 \\
\hline 1 & 0.000 & 0.000 & 0.000 & 0.000 & 0.000 & 0.000 & 0.000 & 0.000 & 0.000 \\
\hline 2 & 0.000 & 0.000 & 0.000 & 0.000 & 0.000 & 0.000 & 0.000 & 0.000 & 0.000 \\
\hline 3 & 0.000 & 0.000 & 0.000 & 0.000 & 0.000 & 0.000 & 0.000 & 0.000 & 0.000 \\
\hline TNX Control & 0.000 & 0.000 & 0.000 & 0.000 & 0.000 & 0.000 & 0.000 & 0.000 & 0.000 \\
\hline St Dev & 0.000 & 0.000 & 0.000 & 0.000 & 0.000 & 0.000 & 0.000 & 0.000 & 0.000 \\
\hline 4 & 0.000 & 0.000 & 0.000 & 0.000 & 0.000 & 0.206 & 0.183 & 0.000 & 0.000 \\
\hline 5 & 0.000 & 0.000 & 0.000 & 0.000 & 0.000 & 0.132 & 0.094 & 0.000 & 0.000 \\
\hline 6 & 0.000 & 0.000 & 0.000 & 0.000 & 0.486 & 0.460 & 0.417 & 0.000 & 0.000 \\
\hline $\begin{array}{l}\text { TNX Corn } \\
\text { Syrup }\end{array}$ & 0.000 & 0.000 & 0.000 & 0.000 & 0.162 & 0.266 & 0.231 & 0.000 & 0.000 \\
\hline St Dev & 0.000 & 0.000 & 0.000 & 0.000 & 0.229 & 0.140 & 0.136 & 0.000 & 0.000 \\
\hline 7 & 0.000 & 0.000 & 0.000 & 0.000 & 0.000 & 0.081 & 0.069 & 0.000 & 0.000 \\
\hline 8 & 0.000 & 0.000 & 0.000 & 0.000 & 0.000 & 0.075 & 0.071 & 0.012 & 0.000 \\
\hline 9 & 0.000 & 0.000 & 0.000 & 0.000 & 0.000 & 0.064 & 0.064 & 0.000 & 0.000 \\
\hline $\begin{array}{l}\text { TNX } \\
\text { Molasses }\end{array}$ & 0.000 & 0.000 & 0.000 & 0.000 & 0.000 & 0.073 & 0.068 & 0.004 & 0.000 \\
\hline St Dev & 0.000 & 0.000 & 0.000 & 0.000 & 0.000 & 0.007 & 0.003 & 0.006 & 0.000 \\
\hline 10 & 0.000 & 0.000 & 0.000 & 0.000 & 0.000 & 0.069 & 0.071 & 0.000 & 0.000 \\
\hline 11 & 0.000 & 0.000 & 0.000 & 0.105 & 0.089 & 0.081 & 0.080 & 0.000 & 0.000 \\
\hline 12 & 0.000 & 0.000 & 0.000 & 0.000 & 0.122 & 0.107 & 0.100 & 0.000 & 0.000 \\
\hline TNX Lactose & 0.000 & 0.000 & 0.000 & 0.035 & 0.070 & 0.086 & 0.084 & 0.000 & 0.000 \\
\hline St Dev & 0.000 & 0.000 & 0.000 & 0.049 & 0.052 & 0.016 & 0.012 & 0.000 & 0.000 \\
\hline 13 & 0.000 & 0.000 & 0.000 & 0.110 & 0.114 & 0.107 & 0.074 & 0.000 & 0.000 \\
\hline 14 & 0.000 & 0.000 & 0.000 & 0.102 & 0.093 & 0.096 & 0.091 & 0.000 & 0.000 \\
\hline 15 & 0.000 & 0.000 & 0.000 & 0.097 & 0.090 & 0.076 & 0.000 & 0.000 & 0.000 \\
\hline TNX EOS & 0.000 & 0.000 & 0.000 & 0.103 & 0.099 & 0.093 & 0.055 & 0.000 & 0.000 \\
\hline St Dev & 0.000 & 0.000 & 0.000 & 0.005 & 0.011 & 0.013 & 0.040 & 0.000 & 0.000 \\
\hline 16 & 0.000 & 0.000 & 0.000 & 0.000 & 0.000 & 0.000 & 0.000 & 0.000 & 0.000 \\
\hline 17 & 0.000 & 0.000 & 0.000 & 0.000 & 0.000 & 0.000 & 0.000 & 0.000 & 0.000 \\
\hline 18 & 0.000 & 0.000 & 0.000 & 0.000 & 0.000 & 0.000 & 0.000 & 0.000 & 0.000 \\
\hline TNX Acetate & 0.000 & 0.000 & 0.000 & 0.000 & 0.000 & 0.000 & 0.000 & 0.000 & 0.000 \\
\hline St Dev & 0.000 & 0.000 & 0.000 & 0.000 & 0.000 & 0.000 & 0.000 & 0.000 & 0.000 \\
\hline
\end{tabular}


Table A9. Run 2 TNT Raw Data.

\begin{tabular}{|c|c|c|c|c|c|}
\hline TNT & 0 & 2 & 7 & 15 & 24 \\
\hline 1 & 1.010 & 0.674 & 0.201 & 0.000 & 0.000 \\
\hline 2 & 0.994 & 0.651 & 0.206 & 0.000 & 0.000 \\
\hline 3 & 1.010 & 0.629 & 0.175 & 0.000 & 0.000 \\
\hline TNT Control & 1.005 & 0.651 & 0.194 & 0.000 & 0.000 \\
\hline St Dev & 0.008 & 0.018 & 0.014 & 0.000 & 0.000 \\
\hline 4 & 1.020 & 0.826 & 0.326 & 0.000 & 0.000 \\
\hline 5 & 1.010 & 0.827 & 0.340 & 0.000 & 0.000 \\
\hline 6 & 1.030 & 0.823 & 0.344 & 0.000 & 0.000 \\
\hline TNT Benzoic Acid & 1.020 & 0.825 & 0.337 & 0.000 & 0.000 \\
\hline St Dev & 0.008 & 0.002 & 0.008 & 0.000 & 0.000 \\
\hline 7 & 1.010 & 0.664 & 0.191 & 0.000 & 0.000 \\
\hline 8 & 0.980 & 0.635 & 0.180 & 0.000 & 0.000 \\
\hline 9 & 1.260 & 0.571 & 0.168 & 0.000 & 0.000 \\
\hline TNT Ethanol & 1.083 & 0.623 & 0.180 & 0.000 & 0.000 \\
\hline St Dev & 0.126 & 0.039 & 0.009 & 0.000 & 0.000 \\
\hline 10 & 0.994 & 0.000 & 0.000 & 0.000 & 0.000 \\
\hline 11 & 0.983 & 0.000 & 0.000 & 0.000 & 0.000 \\
\hline 12 & 1.010 & 0.000 & 0.000 & 0.000 & 0.000 \\
\hline TNT Whey & 0.996 & 0.000 & 0.000 & 0.000 & 0.000 \\
\hline St Dev & 0.011 & 0.000 & 0.000 & 0.000 & 0.000 \\
\hline 13 & 1.040 & 0.759 & 0.199 & 0.000 & 0.000 \\
\hline 14 & 1.010 & 0.699 & 0.168 & 0.000 & 0.000 \\
\hline 15 & 1.020 & 0.718 & 0.202 & 0.000 & 0.000 \\
\hline TNT Na Lactate & 1.023 & 0.725 & 0.190 & 0.000 & 0.000 \\
\hline St Dev & 0.012 & 0.025 & 0.015 & 0.000 & 0.000 \\
\hline 16 & 1.070 & 0.000 & 0.000 & 0.000 & 0.000 \\
\hline 17 & 1.050 & 0.000 & 0.000 & 0.000 & 0.000 \\
\hline 18 & 1.070 & 0.000 & 0.000 & 0.000 & 0.000 \\
\hline TNT L. Soil Lactose & 1.063 & 0.000 & 0.000 & 0.000 & 0.000 \\
\hline St Dev & 0.009 & 0.000 & 0.000 & 0.000 & 0.000 \\
\hline 19 & 1.120 & 1.030 & 0.542 & 0.471 & 0.097 \\
\hline 20 & 1.130 & 1.060 & 0.513 & 0.343 & 0.103 \\
\hline 21 & 1.180 & 0.663 & 0.568 & 0.431 & 0.209 \\
\hline TNT Dead Control & 1.143 & 0.918 & 0.541 & 0.415 & 0.136 \\
\hline St Dev & 0.026 & 0.180 & 0.022 & 0.053 & 0.051 \\
\hline 22 & 1.120 & 0.927 & 0.748 & 0.647 & 0.265 \\
\hline 23 & 1.090 & 0.964 & 0.779 & 0.745 & 0.285 \\
\hline 24 & 1.150 & 0.824 & 0.772 & 0.778 & 0.369 \\
\hline TNT L. Soil Control & 1.120 & 0.905 & 0.766 & 0.723 & 0.306 \\
\hline St Dev & 0.024 & 0.059 & 0.013 & 0.056 & 0.045 \\
\hline
\end{tabular}


Table A10. Run 24 Amino 2,6-dinitroltoluene Raw Data.

\begin{tabular}{|c|c|c|c|c|c|}
\hline 4 Amino 2,6-dinitroltoluene & 0 & 2 & 7 & 15 & 24 \\
\hline 1 & 0.000 & 0.022 & 0.038 & 0.070 & 0.038 \\
\hline 2 & 0.000 & 0.026 & 0.055 & 0.153 & 0.061 \\
\hline 3 & 0.000 & 0.033 & 0.058 & 0.154 & 0.077 \\
\hline 4A26D Control & 0.000 & 0.027 & 0.050 & 0.126 & 0.059 \\
\hline St Dev & 0.000 & 0.005 & 0.009 & 0.039 & 0.016 \\
\hline 4 & 0.000 & 0.000 & 0.027 & 0.139 & 0.143 \\
\hline 5 & 0.000 & 0.010 & 0.066 & 0.181 & 0.195 \\
\hline 6 & 0.000 & 0.000 & 0.034 & 0.165 & 0.155 \\
\hline 4A26D Benzoic Acid & 0.000 & 0.003 & 0.042 & 0.162 & 0.164 \\
\hline St Dev & 0.000 & 0.005 & 0.017 & 0.017 & 0.022 \\
\hline 7 & 0.000 & 0.019 & 0.056 & 0.165 & 0.041 \\
\hline 8 & 0.000 & 0.019 & 0.052 & 0.122 & 0.000 \\
\hline 9 & 0.000 & 0.030 & 0.080 & 0.147 & 0.067 \\
\hline 4A26D Ethanol & 0.000 & 0.023 & 0.063 & 0.145 & 0.036 \\
\hline St Dev & 0.000 & 0.005 & 0.012 & 0.018 & 0.028 \\
\hline 10 & 0.000 & 0.000 & 0.000 & 0.216 & 0.000 \\
\hline 11 & 0.000 & 0.241 & 0.000 & 0.315 & 0.000 \\
\hline 12 & 0.000 & 0.000 & 0.000 & 0.000 & 0.000 \\
\hline 4A26D Whey & 0.000 & 0.080 & 0.000 & 0.177 & 0.000 \\
\hline St Dev & 0.000 & 0.114 & 0.000 & 0.132 & 0.000 \\
\hline 13 & 0.000 & 0.018 & 0.066 & 0.100 & 0.000 \\
\hline 14 & 0.000 & 0.020 & 0.080 & 0.000 & 0.000 \\
\hline 15 & 0.000 & 0.013 & 0.064 & 0.000 & 0.000 \\
\hline 4A26D Na Lactate & 0.000 & 0.017 & 0.070 & 0.033 & 0.000 \\
\hline St Dev & 0.000 & 0.003 & 0.007 & 0.047 & 0.000 \\
\hline 16 & 0.000 & 0.000 & 0.000 & 0.011 & 0.000 \\
\hline 17 & 0.000 & 0.000 & 0.000 & 0.033 & 0.000 \\
\hline 18 & 0.000 & 0.000 & 0.000 & 0.032 & 0.000 \\
\hline 4A26D L. Soil Lactose & 0.000 & 0.000 & 0.000 & 0.025 & 0.000 \\
\hline St Dev & 0.000 & 0.000 & 0.000 & 0.010 & 0.000 \\
\hline 19 & 0.000 & 0.000 & 0.036 & 0.048 & 0.068 \\
\hline 20 & 0.000 & 0.000 & 0.025 & 0.059 & 0.060 \\
\hline 21 & 0.000 & 0.000 & 0.044 & 0.067 & 0.058 \\
\hline 4A26D Dead Control & 0.000 & 0.000 & 0.035 & 0.058 & 0.062 \\
\hline St Dev & 0.000 & 0.000 & 0.008 & 0.008 & 0.004 \\
\hline 22 & 0.000 & 0.000 & 0.000 & 0.010 & 0.037 \\
\hline 23 & 0.000 & 0.000 & 0.000 & 0.011 & 0.043 \\
\hline 24 & 0.000 & 0.000 & 0.000 & 0.011 & 0.051 \\
\hline 4A26D L. Soil Control & 0.000 & 0.000 & 0.000 & 0.011 & 0.044 \\
\hline St Dev & 0.000 & 0.000 & 0.000 & 0.000 & 0.006 \\
\hline
\end{tabular}


Table A11. Run 22 Amino 4,6 dinitrotoluene Raw Data.

\begin{tabular}{|c|c|c|c|c|c|}
\hline 2 Amino 4,6 dinitrotoluene & 0 & 2 & 7 & 15 & 24 \\
\hline 1 & 0.000 & 0.000 & 0.014 & 0.000 & 0.000 \\
\hline 2 & 0.000 & 0.000 & 0.015 & 0.000 & 0.000 \\
\hline 3 & 0.000 & 0.000 & 0.023 & 0.030 & 0.000 \\
\hline 2A46D Control & 0.000 & 0.000 & 0.017 & 0.010 & 0.000 \\
\hline St Dev & 0.000 & 0.000 & 0.004 & 0.014 & 0.000 \\
\hline 4 & 0.000 & 0.000 & 0.012 & 0.035 & 0.000 \\
\hline 5 & 0.000 & 0.000 & 0.048 & 0.049 & 0.000 \\
\hline 6 & 0.000 & 0.000 & 0.015 & 0.038 & 0.000 \\
\hline 2A46D Benzoic Acid & 0.000 & 0.000 & 0.025 & 0.041 & 0.000 \\
\hline St Dev & 0.000 & 0.000 & 0.016 & 0.006 & 0.000 \\
\hline 7 & 0.000 & 0.000 & 0.000 & 0.010 & 0.000 \\
\hline 8 & 0.000 & 0.000 & 0.010 & 0.000 & 0.000 \\
\hline 9 & 0.000 & 0.000 & 0.029 & 0.020 & 0.000 \\
\hline 2A46D Ethanol & 0.000 & 0.000 & 0.013 & 0.010 & 0.000 \\
\hline St Dev & 0.000 & 0.000 & 0.012 & 0.008 & 0.000 \\
\hline 10 & 0.000 & 0.000 & 0.000 & 0.000 & 0.000 \\
\hline 11 & 0.000 & 0.000 & 0.000 & 0.000 & 0.000 \\
\hline 12 & 0.000 & 0.000 & 0.000 & 0.000 & 0.000 \\
\hline 2A46D Whey & 0.000 & 0.000 & 0.000 & 0.000 & 0.000 \\
\hline St Dev & 0.000 & 0.000 & 0.000 & 0.000 & 0.000 \\
\hline 13 & 0.000 & 0.000 & 0.016 & 0.000 & 0.000 \\
\hline 14 & 0.000 & 0.000 & 0.016 & 0.000 & 0.000 \\
\hline 15 & 0.000 & 0.000 & 0.014 & 0.000 & 0.000 \\
\hline 2A46D Na Lactate & 0.000 & 0.000 & 0.015 & 0.000 & 0.000 \\
\hline St Dev & 0.000 & 0.000 & 0.001 & 0.000 & 0.000 \\
\hline 16 & 0.000 & 0.000 & 0.000 & 0.000 & 0.000 \\
\hline 17 & 0.000 & 0.000 & 0.000 & 0.000 & 0.000 \\
\hline 18 & 0.000 & 0.000 & 0.000 & 0.000 & 0.000 \\
\hline 2A46D L. Soil Lactose & 0.000 & 0.000 & 0.000 & 0.000 & 0.000 \\
\hline St Dev & 0.000 & 0.000 & 0.000 & 0.000 & 0.000 \\
\hline 19 & 0.000 & 0.000 & 0.010 & 0.015 & 0.038 \\
\hline 20 & 0.000 & 0.000 & 0.000 & 0.025 & 0.049 \\
\hline 21 & 0.000 & 0.000 & 0.018 & 0.015 & 0.040 \\
\hline 2A46D Dead Control & 0.000 & 0.000 & 0.009 & 0.018 & 0.042 \\
\hline St Dev & 0.000 & 0.000 & 0.007 & 0.005 & 0.005 \\
\hline 22 & 0.000 & 0.000 & 0.000 & 0.000 & 0.017 \\
\hline 23 & 0.000 & 0.000 & 0.000 & 0.000 & 0.021 \\
\hline 24 & 0.000 & 0.000 & 0.000 & 0.000 & 0.027 \\
\hline 2A46D L. Soil Control & 0.000 & 0.000 & 0.000 & 0.000 & 0.022 \\
\hline St Dev & 0.000 & 0.000 & 0.000 & 0.000 & 0.004 \\
\hline
\end{tabular}


Table A12. Run 2 HMX Raw Data.

\begin{tabular}{|c|c|c|c|c|c|}
\hline HMX & 0 & 2 & 7 & 15 & 24 \\
\hline 1 & 0.659 & 1.200 & 1.420 & 1.430 & 1.240 \\
\hline 2 & 0.666 & 1.110 & 1.270 & 1.380 & 1.170 \\
\hline 3 & 0.633 & 1.150 & 1.340 & 1.370 & 1.220 \\
\hline HMX Control & 0.653 & 1.153 & 1.343 & 1.393 & 1.210 \\
\hline St Dev & 0.014 & 0.037 & 0.061 & 0.026 & 0.029 \\
\hline 4 & 0.547 & 1.100 & 4.640 & 1.330 & 1.230 \\
\hline 5 & 0.685 & 1.230 & 4.430 & 1.490 & 1.400 \\
\hline 6 & 0.624 & 1.120 & 4.220 & 1.380 & 1.210 \\
\hline HMX Benzoic Acid & 0.619 & 1.150 & 4.430 & 1.400 & 1.280 \\
\hline St Dev & 0.056 & 0.057 & 0.171 & 0.067 & 0.085 \\
\hline 7 & 0.548 & 1.150 & 1.370 & 1.380 & 1.220 \\
\hline 8 & 0.523 & 1.110 & 1.380 & 1.470 & 0.000 \\
\hline 9 & 0.645 & 1.040 & 1.350 & 1.390 & 1.070 \\
\hline HMX Ethanol & 0.572 & 1.100 & 1.367 & 1.413 & 0.763 \\
\hline St Dev & 0.053 & 0.045 & 0.012 & 0.040 & 0.543 \\
\hline 10 & 0.466 & 1.140 & 1.040 & 0.000 & 0.000 \\
\hline 11 & 0.427 & 0.970 & 1.680 & 0.076 & 0.000 \\
\hline 12 & 0.466 & 1.550 & 1.130 & 0.000 & 0.000 \\
\hline HMX Whey & 0.453 & 1.220 & 1.283 & 0.025 & 0.000 \\
\hline St Dev & 0.018 & 0.243 & 0.283 & 0.036 & 0.000 \\
\hline 13 & 0.494 & 1.010 & 1.330 & 1.330 & 1.320 \\
\hline 14 & 0.617 & 1.060 & 1.340 & 1.460 & 1.020 \\
\hline 15 & 0.504 & 1.030 & 1.320 & 1.370 & 0.914 \\
\hline HMX Na Lactate & 0.538 & 1.033 & 1.330 & 1.387 & 1.085 \\
\hline St Dev & 0.056 & 0.021 & 0.008 & 0.054 & 0.172 \\
\hline 16 & 0.127 & 0.462 & 0.212 & 0.348 & 0.273 \\
\hline 17 & 0.165 & 0.430 & 0.271 & 0.358 & 0.257 \\
\hline 18 & 0.154 & 0.447 & 0.220 & 0.374 & 0.245 \\
\hline HMX L. Soil Lactose & 0.149 & 0.446 & 0.234 & 0.360 & 0.258 \\
\hline St Dev & 0.016 & 0.013 & 0.026 & 0.011 & 0.011 \\
\hline 19 & 0.728 & 0.800 & 0.815 & 0.794 & 0.678 \\
\hline 20 & 0.729 & 0.787 & 0.734 & 0.761 & 0.673 \\
\hline 21 & 0.746 & 0.539 & 0.946 & 0.944 & 0.795 \\
\hline HMX Dead Control & 0.734 & 0.709 & 0.832 & 0.833 & 0.715 \\
\hline St Dev & 0.008 & 0.120 & 0.087 & 0.080 & 0.056 \\
\hline 22 & 0.155 & 0.275 & 0.354 & 0.311 & 0.287 \\
\hline 23 & 0.147 & 0.323 & 0.403 & 0.339 & 0.343 \\
\hline 24 & 0.108 & 0.233 & 0.344 & 0.282 & 0.319 \\
\hline HMX L. Soil Control & 0.137 & 0.277 & 0.367 & 0.311 & 0.316 \\
\hline St Dev & 0.021 & 0.037 & 0.026 & 0.023 & 0.023 \\
\hline
\end{tabular}


Table A13. Run 2 RDX Raw Data.

\begin{tabular}{|c|c|c|c|c|c|}
\hline RDX & 0 & 2 & 7 & 15 & 24 \\
\hline 1 & 0.826 & 0.830 & 0.753 & 0.798 & 0.622 \\
\hline 2 & 0.800 & 0.801 & 0.745 & 0.759 & 0.629 \\
\hline 3 & 0.819 & 0.808 & 0.756 & 0.760 & 0.641 \\
\hline RDX Control & 0.815 & 0.813 & 0.751 & 0.772 & 0.631 \\
\hline St Dev & 0.011 & 0.012 & 0.005 & 0.018 & 0.008 \\
\hline 4 & 0.791 & 0.788 & 0.754 & 0.820 & 0.718 \\
\hline 5 & 0.810 & 0.828 & 0.742 & 0.833 & 0.726 \\
\hline 6 & 0.816 & 0.793 & 0.767 & 0.775 & 0.646 \\
\hline RDX Benzoic Acid & 0.806 & 0.803 & 0.754 & 0.809 & 0.697 \\
\hline St Dev & 0.011 & 0.018 & 0.010 & 0.025 & 0.036 \\
\hline 7 & 0.805 & 0.798 & 0.719 & 0.775 & 0.621 \\
\hline 8 & 0.772 & 0.796 & 0.739 & 0.769 & 0.000 \\
\hline 9 & 1.020 & 0.753 & 0.728 & 0.723 & 0.539 \\
\hline RDX Ethanol & 0.866 & 0.782 & 0.729 & 0.756 & 0.387 \\
\hline St Dev & 0.110 & 0.021 & 0.008 & 0.023 & 0.275 \\
\hline 10 & 0.761 & 0.492 & 0.000 & 0.000 & 0.000 \\
\hline 11 & 0.757 & 0.754 & 0.000 & 0.026 & 0.000 \\
\hline 12 & 0.773 & 0.172 & 0.000 & 0.000 & 0.000 \\
\hline RDX Whey & 0.764 & 0.473 & 0.000 & 0.009 & 0.000 \\
\hline St Dev & 0.007 & 0.238 & 0.000 & 0.012 & 0.000 \\
\hline 13 & 0.792 & 0.801 & 0.763 & 0.775 & 0.440 \\
\hline 14 & 0.777 & 0.773 & 0.727 & 0.681 & 0.263 \\
\hline 15 & 0.794 & 0.796 & 0.762 & 0.729 & 0.205 \\
\hline RDX Na Lactate & 0.788 & 0.790 & 0.751 & 0.728 & 0.303 \\
\hline St Dev & 0.008 & 0.012 & 0.017 & 0.038 & 0.100 \\
\hline 16 & 0.725 & 0.123 & 0.000 & 0.000 & 0.000 \\
\hline 17 & 0.723 & 0.016 & 0.000 & 0.000 & 0.000 \\
\hline 18 & 0.763 & 0.079 & 0.000 & 0.000 & 0.000 \\
\hline RDX L. Soil Lactose & 0.737 & 0.073 & 0.000 & 0.000 & 0.000 \\
\hline St Dev & 0.018 & 0.044 & 0.000 & 0.000 & 0.000 \\
\hline 19 & 0.643 & 0.620 & 0.722 & 0.541 & 0.468 \\
\hline 20 & 0.637 & 0.638 & 0.653 & 0.545 & 0.508 \\
\hline 21 & 0.680 & 0.402 & 0.705 & 0.550 & 0.486 \\
\hline RDX Dead Control & 0.653 & 0.553 & 0.693 & 0.545 & 0.487 \\
\hline St Dev & 0.019 & 0.107 & 0.029 & 0.004 & 0.016 \\
\hline 22 & 0.631 & 0.554 & 0.575 & 0.585 & 0.479 \\
\hline 23 & 0.620 & 0.572 & 0.598 & 0.603 & 0.518 \\
\hline 24 & 0.618 & 0.478 & 0.567 & 0.562 & 0.530 \\
\hline RDX L. Soil Control & 0.623 & 0.535 & 0.580 & 0.583 & 0.509 \\
\hline St Dev & 0.006 & 0.041 & 0.013 & 0.017 & 0.022 \\
\hline
\end{tabular}


Table A14. Run 2 MNX Raw Data.

\begin{tabular}{|l|l|l|l|l|l|}
\hline MNX & 0 & 2 & 7 & 15 & 24 \\
\hline 1 & 0.000 & 0.000 & 0.000 & 0.000 & 0.000 \\
\hline 2 & 0.000 & 0.000 & 0.000 & 0.000 & 0.000 \\
\hline 3 & 0.000 & 0.000 & 0.000 & 0.000 & 0.000 \\
\hline MNX Control & 0.000 & 0.000 & 0.000 & 0.000 & 0.000 \\
\hline St Dev & 0.000 & 0.000 & 0.000 & 0.000 & 0.000 \\
\hline 4 & 0.000 & 0.000 & 0.000 & 0.000 & 0.000 \\
\hline 5 & 0.000 & 0.000 & 0.000 & 0.000 & 0.000 \\
\hline 6 & 0.000 & 0.000 & 0.000 & 0.000 & 0.008 \\
\hline MNX Benzoic Acid & 0.000 & 0.000 & 0.000 & 0.000 & 0.003 \\
\hline St Dev & 0.000 & 0.000 & 0.000 & 0.000 & 0.004 \\
\hline 7 & 0.000 & 0.000 & 0.000 & 0.000 & 0.028 \\
\hline 8 & 0.000 & 0.000 & 0.000 & 0.066 & 0.000 \\
\hline 9 & 0.000 & 0.000 & 0.000 & 0.057 & 0.000 \\
\hline MNX Ethanol & 0.000 & 0.000 & 0.000 & 0.041 & 0.009 \\
\hline St Dev & 0.000 & 0.000 & 0.000 & 0.029 & 0.013 \\
\hline 10 & 0.000 & 0.223 & 0.106 & 0.000 & 0.000 \\
\hline 11 & 0.000 & 0.000 & 0.133 & 0.000 & 0.000 \\
\hline 12 & 0.000 & 0.037 & 0.116 & 0.000 & 0.000 \\
\hline MNX Whey & 0.000 & 0.087 & 0.118 & 0.000 & 0.000 \\
\hline St Dev & 0.000 & 0.098 & 0.011 & 0.000 & 0.000 \\
\hline 13 & 0.000 & 0.000 & 0.000 & 0.000 & 0.102 \\
\hline 14 & 0.000 & 0.000 & 0.000 & 0.073 & 0.046 \\
\hline 15 & 0.000 & 0.000 & 0.000 & 0.065 & 0.055 \\
\hline MNX Na Lactate & 0.000 & 0.000 & 0.000 & 0.046 & 0.068 \\
\hline St Dev & 0.000 & 0.000 & 0.000 & 0.033 & 0.025 \\
\hline 16 & 0.000 & 0.384 & 0.086 & 0.095 & 0.000 \\
\hline 17 & 0.000 & 0.330 & 0.105 & 0.106 & 0.000 \\
\hline 18 & 0.000 & 0.381 & 0.086 & 0.097 & 0.000 \\
\hline MNX L. Soil Lactose & 0.000 & 0.365 & 0.092 & 0.099 & 0.000 \\
\hline St Dev & 0.000 & 0.025 & 0.009 & 0.005 & 0.000 \\
\hline 19 & 0.000 & 0.000 & 0.000 & 0.000 & 0.000 \\
\hline 20 & 0.000 & 0.000 & 0.000 & 0.000 & 0.000 \\
\hline 21 & 0.000 & 0.000 & 0.000 & 0.000 & 0.000 \\
\hline MNX Dead Control & 0.000 & 0.000 & 0.000 & 0.000 \\
\hline St Dev & 0.000 & 0.000 & 0.000 & 0.000 \\
\hline 22 & 0.000 & 0.000 & 0.000 \\
\hline 23 & 0.000 & 0.000 & 0.000 \\
\hline St Dev & 0.000 & 0.000 & 0.000 \\
\hline & 0.000 & 0.000 & 0.000 \\
\hline 19.000 & 0.000 \\
\hline
\end{tabular}


Table A15. Run 2 DNX Raw Data.

\begin{tabular}{|c|c|c|c|c|c|}
\hline DNX & 0 & 2 & 7 & 15 & 24 \\
\hline 1 & 0.000 & 0.000 & 0.000 & 0.000 & 0.000 \\
\hline 2 & 0.000 & 0.000 & 0.000 & 0.000 & 0.000 \\
\hline 3 & 0.000 & 0.000 & 0.000 & 0.000 & 0.000 \\
\hline DNX Control & 0.000 & 0.000 & 0.000 & 0.000 & 0.000 \\
\hline St Dev & 0.000 & 0.000 & 0.000 & 0.000 & 0.000 \\
\hline 4 & 0.000 & 0.000 & 0.000 & 0.000 & 0.000 \\
\hline 5 & 0.000 & 0.000 & 0.000 & 0.000 & 0.000 \\
\hline 6 & 0.000 & 0.000 & 0.000 & 0.000 & 0.000 \\
\hline DNX Benzoic Acid & 0.000 & 0.000 & 0.000 & 0.000 & 0.000 \\
\hline St Dev & 0.000 & 0.000 & 0.000 & 0.000 & 0.000 \\
\hline 7 & 0.000 & 0.000 & 0.070 & 0.000 & 0.000 \\
\hline 8 & 0.000 & 0.000 & 0.076 & 0.000 & 0.000 \\
\hline 9 & 0.000 & 0.000 & 0.074 & 0.000 & 0.000 \\
\hline DNX Ethanol & 0.000 & 0.000 & 0.073 & 0.000 & 0.000 \\
\hline St Dev & 0.000 & 0.000 & 0.002 & 0.000 & 0.000 \\
\hline 10 & 0.000 & 0.000 & 0.293 & 0.000 & 0.000 \\
\hline 11 & 0.000 & 0.000 & 0.239 & 0.000 & 0.000 \\
\hline 12 & 0.000 & 0.118 & 0.345 & 0.000 & 0.000 \\
\hline DNX Whey & 0.000 & 0.039 & 0.292 & 0.000 & 0.000 \\
\hline St Dev & 0.000 & 0.056 & 0.043 & 0.000 & 0.000 \\
\hline 13 & 0.000 & 0.000 & 0.000 & 0.000 & 0.000 \\
\hline 14 & 0.000 & 0.000 & 0.000 & 0.000 & 0.000 \\
\hline 15 & 0.000 & 0.000 & 0.000 & 0.000 & 0.000 \\
\hline DNX Na Lactate & 0.000 & 0.000 & 0.000 & 0.000 & 0.000 \\
\hline St Dev & 0.000 & 0.000 & 0.000 & 0.000 & 0.000 \\
\hline 16 & 0.000 & 0.141 & 0.175 & 0.348 & 0.000 \\
\hline 17 & 0.000 & 0.266 & 0.213 & 0.139 & 0.000 \\
\hline 18 & 0.000 & 0.200 & 0.140 & 0.117 & 0.000 \\
\hline DNX L. Soil Lactose & 0.000 & 0.202 & 0.176 & 0.201 & 0.000 \\
\hline St Dev & 0.000 & 0.051 & 0.030 & 0.104 & 0.000 \\
\hline 19 & 0.061 & 0.000 & 0.071 & 0.000 & 0.000 \\
\hline 20 & 0.000 & 0.088 & 0.000 & 0.000 & 0.000 \\
\hline 21 & 0.000 & 0.000 & 0.000 & 0.000 & 0.000 \\
\hline DNX Dead Control & 0.020 & 0.029 & 0.024 & 0.000 & 0.000 \\
\hline St Dev & 0.029 & 0.041 & 0.033 & 0.000 & 0.000 \\
\hline 22 & 0.000 & 0.000 & 0.000 & 0.000 & 0.000 \\
\hline 23 & 0.000 & 0.000 & 0.000 & 0.000 & 0.000 \\
\hline 24 & 0.000 & 0.000 & 0.070 & 0.000 & 0.000 \\
\hline DNX L. Soil Control & 0.000 & 0.000 & 0.023 & 0.000 & 0.000 \\
\hline St Dev & 0.000 & 0.000 & 0.033 & 0.000 & 0.000 \\
\hline
\end{tabular}


Table A16. Run 2 TNX Raw Data.

\begin{tabular}{|c|c|c|c|c|c|}
\hline TNX & 0 & 2 & 7 & 15 & 24 \\
\hline 1 & 0.000 & 0.000 & 0.000 & 0.107 & 0.000 \\
\hline 2 & 0.000 & 0.000 & 0.000 & 0.171 & 0.000 \\
\hline 3 & 0.000 & 0.000 & 0.000 & 0.000 & 0.000 \\
\hline TNX Control & 0.000 & 0.000 & 0.000 & 0.093 & 0.000 \\
\hline St Dev & 0.000 & 0.000 & 0.000 & 0.071 & 0.000 \\
\hline 4 & 0.000 & 0.000 & 0.000 & 0.072 & 0.000 \\
\hline 5 & 0.000 & 0.000 & 0.000 & 0.071 & 0.000 \\
\hline 6 & 0.000 & 0.000 & 0.000 & 0.072 & 0.000 \\
\hline TNX Benzoic Acid & 0.000 & 0.000 & 0.000 & 0.072 & 0.000 \\
\hline St Dev & 0.000 & 0.000 & 0.000 & 0.000 & 0.000 \\
\hline 7 & 0.000 & 0.000 & 0.000 & 0.111 & 0.000 \\
\hline 8 & 0.000 & 0.000 & 0.000 & 0.156 & 0.000 \\
\hline 9 & 0.000 & 0.000 & 0.000 & 0.139 & 0.000 \\
\hline TNX Ethanol & 0.000 & 0.000 & 0.000 & 0.135 & 0.000 \\
\hline St Dev & 0.000 & 0.000 & 0.000 & 0.019 & 0.000 \\
\hline 10 & 0.000 & 0.000 & 0.076 & 0.000 & 0.000 \\
\hline 11 & 0.000 & 0.000 & 0.000 & 0.127 & 0.000 \\
\hline 12 & 0.000 & 0.000 & 0.075 & 0.000 & 0.000 \\
\hline TNX Whey & 0.000 & 0.000 & 0.050 & 0.042 & 0.000 \\
\hline St Dev & 0.000 & 0.000 & 0.036 & 0.060 & 0.000 \\
\hline 13 & 0.000 & 0.000 & 0.000 & 0.105 & 0.000 \\
\hline 14 & 0.000 & 0.000 & 0.000 & 0.211 & 0.000 \\
\hline 15 & 0.000 & 0.000 & 0.000 & 0.166 & 0.000 \\
\hline TNX Na Lactate & 0.000 & 0.000 & 0.000 & 0.161 & 0.000 \\
\hline St Dev & 0.000 & 0.000 & 0.000 & 0.043 & 0.000 \\
\hline 16 & 0.000 & 0.000 & 0.185 & 0.243 & 0.119 \\
\hline 17 & 0.000 & 0.071 & 0.184 & 0.224 & 0.059 \\
\hline 18 & 0.000 & 0.062 & 0.149 & 0.215 & 0.055 \\
\hline TNX L. Soil Lactose & 0.000 & 0.044 & 0.173 & 0.227 & 0.078 \\
\hline St Dev & 0.000 & 0.032 & 0.017 & 0.012 & 0.029 \\
\hline 19 & 0.000 & 0.000 & 0.000 & 0.094 & 0.000 \\
\hline 20 & 0.068 & 0.000 & 0.000 & 0.103 & 0.000 \\
\hline 21 & 0.066 & 0.000 & 0.000 & 0.104 & 0.000 \\
\hline TNX Dead Control & 0.045 & 0.000 & 0.000 & 0.100 & 0.000 \\
\hline St Dev & 0.032 & 0.000 & 0.000 & 0.004 & 0.000 \\
\hline 22 & 0.000 & 0.000 & 0.000 & 0.000 & 0.000 \\
\hline 23 & 0.000 & 0.000 & 0.000 & 0.000 & 0.000 \\
\hline 24 & 0.000 & 0.000 & 0.000 & 0.000 & 0.000 \\
\hline TNX L. Soil Control & 0.000 & 0.000 & 0.000 & 0.000 & 0.000 \\
\hline St Dev & 0.000 & 0.000 & 0.000 & 0.000 & 0.000 \\
\hline
\end{tabular}




\section{Appendix B: Kinetic Analysis of Bioremediation Data}

Table B1. TNT Run 1.

\begin{tabular}{|c|c|c|c|c|c|c|c|}
\hline TNT & Day & TNT Control & TNT Corn Syrup & TNT Molasses & TNT Lactose & TNT EOS & TNT Acetate \\
\hline 24-Feb-10 & 0 & 1.020 & 1.030 & 1.037 & 1.073 & 0.569 & 1.097 \\
\hline 25-Feb-10 & 1 & 0.812 & 0.699 & 0.453 & 0.164 & 0.398 & 0.770 \\
\hline 26-Feb-10 & 2 & 0.597 & 0.470 & 0.000 & 0.000 & 0.126 & 0.560 \\
\hline 1-Mar-10 & 5 & 0.242 & 0.000 & 0.000 & 0.000 & 0.000 & 0.222 \\
\hline 4-Mar-10 & 8 & 0.148 & 0.000 & 0.000 & 0.000 & 0.000 & 0.049 \\
\hline 8-Mar-10 & 12 & 0.000 & 0.000 & 0.000 & 0.000 & 0.000 & 0.000 \\
\hline 11-Mar-10 & 15 & 0.000 & 0.000 & 0.000 & 0.000 & 0.000 & 0.000 \\
\hline 16-Mar-10 & 20 & 0.000 & 0.000 & 0.000 & 0.000 & 0.000 & 0.000 \\
\hline 23-Mar-10 & 27 & 0.000 & 0.000 & 0.000 & 0.000 & 0.000 & 0.000 \\
\hline \multirow[t]{10}{*}{$\ln (\mathrm{Co} / \mathrm{C})$} & Day & Control & Corn Syrup & Molasses & Lactose & EOS & Acetate \\
\hline & 0 & 0.000 & 0.000 & 0.000 & 0.000 & 0.000 & 0.000 \\
\hline & 1 & 0.228 & 0.388 & 0.827 & 1.879 & 0.357 & 0.354 \\
\hline & 2 & 0.535 & 0.784 & & & 1.508 & 0.672 \\
\hline & 5 & 1.439 & & & & & 1.599 \\
\hline & 8 & 1.928 & & & & & 3.115 \\
\hline & 12 & & & & & & \\
\hline & 15 & & & & & & \\
\hline & 20 & & & & & & \\
\hline & 27 & & & & & & \\
\hline k & & 0.254 & 0.391 & 0.827 & 1.879 & 0.674 & 0.368 \\
\hline$r^{\wedge} 2$ & & 0.985 & 1.000 & 1.000 & 1.000 & 0.898 & 0.985 \\
\hline $\mathrm{t}(.5)[=]$ days & & 2.725 & 1.772 & 0.838 & 0.369 & 1.028 & 1.883 \\
\hline
\end{tabular}


Table B2. RDX Run 1.

\begin{tabular}{|c|c|c|c|c|c|c|c|}
\hline RDX & Day & RDX Control & RDX Corn Syrup & RDX Molasses & RDX Lactose & RDX EOS & RDX Acetate \\
\hline 24-Feb-10 & 0 & 0.754 & 0.779 & 0.764 & 0.757 & 0.736 & 0.779 \\
\hline 25-Feb-10 & 1 & 0.807 & 0.774 & 0.750 & 0.712 & 0.749 & 0.765 \\
\hline 26-Feb-10 & 2 & 0.911 & 0.860 & 0.699 & 0.665 & 0.755 & 0.789 \\
\hline 1-Mar-10 & 5 & 0.790 & 0.298 & 0.491 & 0.084 & 0.002 & 0.789 \\
\hline 4-Mar-10 & 8 & 0.739 & 0.146 & 0.022 & 0.000 & 0.000 & 0.773 \\
\hline 8-Mar-10 & 12 & 0.746 & 0.044 & 0.000 & 0.000 & 0.000 & 0.747 \\
\hline 11-Mar-10 & 15 & 0.738 & 0.000 & 0.000 & 0.000 & 0.000 & 0.740 \\
\hline 16-Mar-10 & 20 & 0.583 & 0.000 & 0.000 & 0.000 & 0.000 & 0.652 \\
\hline 23-Mar-10 & 27 & 0.559 & 0.000 & 0.000 & 0.000 & 0.000 & 0.519 \\
\hline \multirow[t]{10}{*}{$\ln (\mathrm{Co} / \mathrm{C})$} & Day & Control & Corn Syrup & Molasses & Lactose & EOS & Acetate \\
\hline & 0 & 0.000 & 0.000 & 0.000 & 0.000 & 0.000 & 0.000 \\
\hline & 1 & \begin{tabular}{|l|}
-0.068 \\
\end{tabular} & 0.007 & 0.019 & 0.061 & -0.018 & 0.018 \\
\hline & 2 & -0.189 & -0.099 & 0.089 & 0.130 & -0.025 & -0.012 \\
\hline & 5 & -0.046 & 0.961 & 0.442 & 2.199 & 5.909 & -0.013 \\
\hline & 8 & 0.020 & 1.677 & 3.533 & & & 0.007 \\
\hline & 12 & 0.011 & 2.866 & & & & 0.042 \\
\hline & 15 & 0.022 & & & & & 0.051 \\
\hline & 20 & 0.257 & & & & & 0.178 \\
\hline & 27 & 0.299 & & & & & 0.407 \\
\hline$k$ & & 0.008 & 0.220 & 0.326 & 0.377 & 0.983 & 0.010 \\
\hline$r^{\wedge} 2$ & & 0.522 & 0.942 & 0.714 & 0.829 & 0.774 & 0.699 \\
\hline $\mathrm{t}(.5)[=]$ days & & 83.512 & 3.146 & 2.124 & 1.838 & 0.705 & 70.015 \\
\hline
\end{tabular}




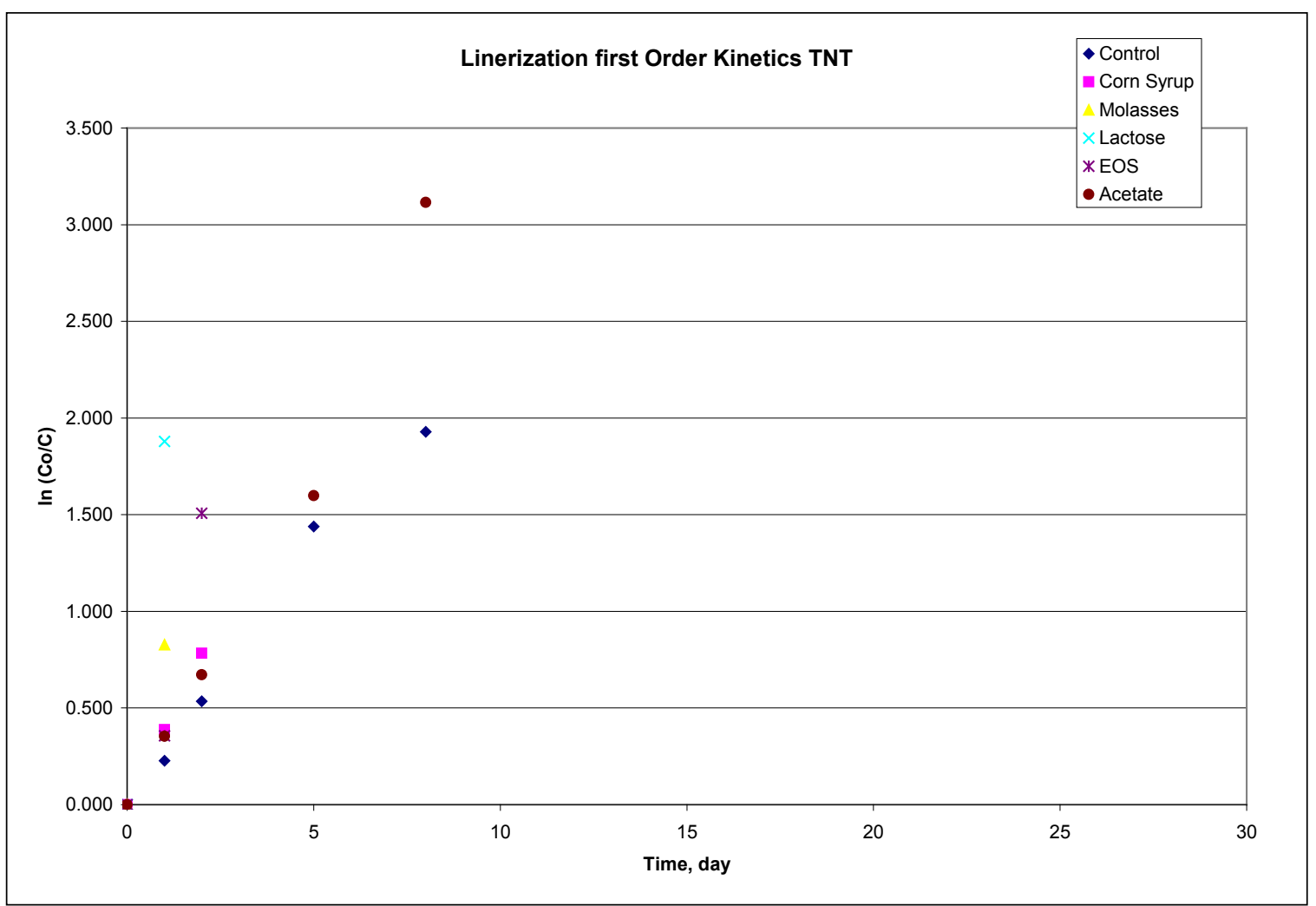

Figure B1. Plot of first-order function linearization TNT Run 1.

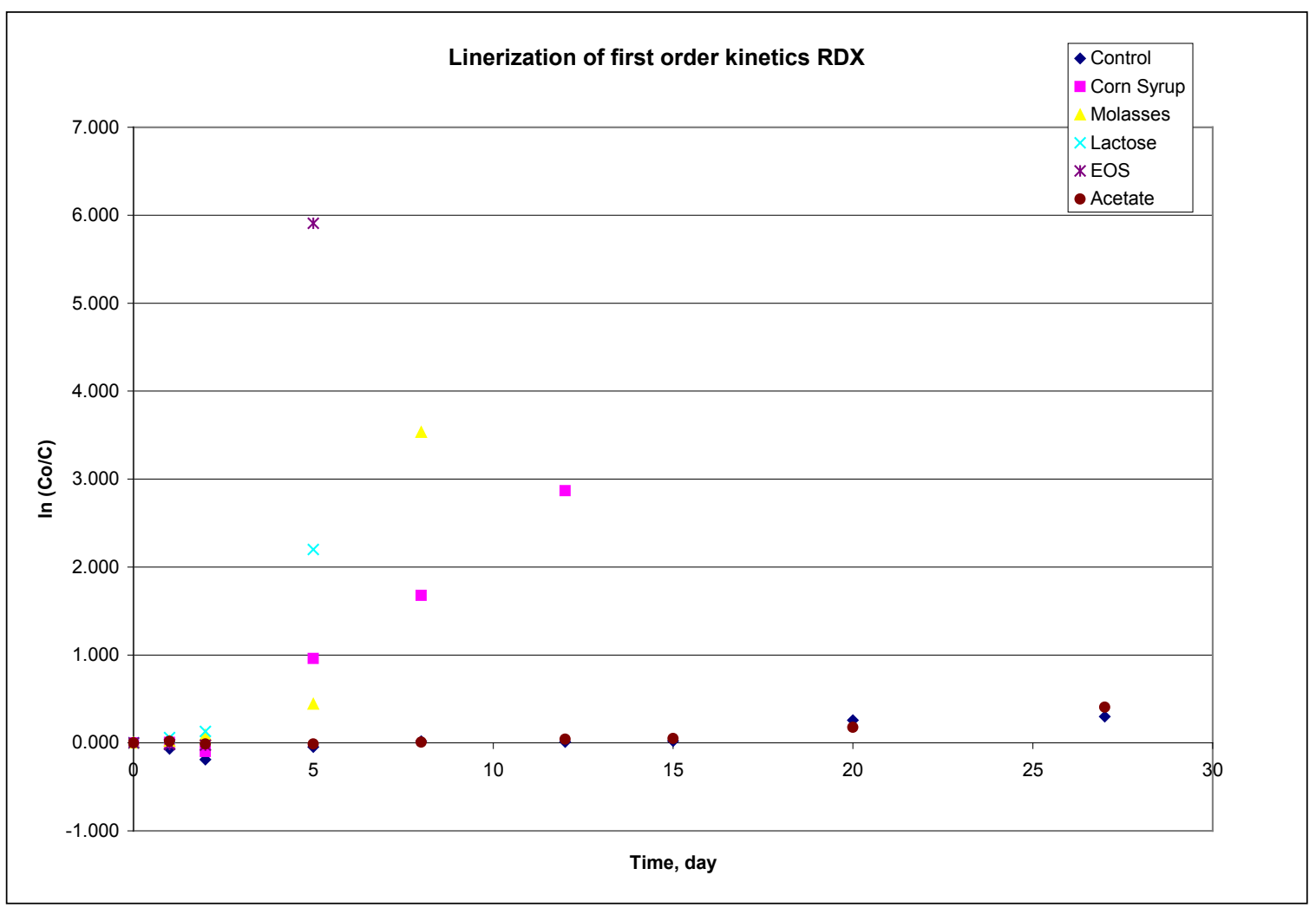

Figure B2. Plot of first-order function linearization RDX Run 1. 
Table B3. TNT Run 2

\begin{tabular}{|c|c|c|c|c|c|c|c|c|}
\hline TNT & $\begin{array}{l}\text { TNT } \\
\text { Control }\end{array}$ & $\begin{array}{l}\text { TNT Benzoic } \\
\text { Acid }\end{array}$ & \begin{tabular}{|l|} 
TNT \\
Ethanol
\end{tabular} & TNT Whey & \begin{tabular}{|l|} 
TNT Na \\
Lactate
\end{tabular} & \begin{tabular}{|l} 
TNT L. Soil \\
Lactose
\end{tabular} & \begin{tabular}{|l} 
TNT Dead \\
Control
\end{tabular} & $\begin{array}{l}\text { TNT L. Soil } \\
\text { Control }\end{array}$ \\
\hline 0 & 1.005 & 1.020 & 1.083 & 0.996 & 1.023 & 1.063 & 1.143 & 1.120 \\
\hline 2 & 0.651 & 0.825 & 0.623 & 0.002 & 0.725 & 0.002 & 0.918 & 0.905 \\
\hline 7 & 0.194 & 0.337 & 0.180 & 0.000 & 0.190 & 0.000 & 0.541 & 0.766 \\
\hline 15 & 0.000 & 0.000 & 0.000 & 0.000 & 0.000 & 0.000 & 0.415 & 0.723 \\
\hline 24 & 0.000 & 0.000 & 0.000 & 0.000 & 0.000 & 0.000 & 0.136 & 0.306 \\
\hline & & & & & & & & \\
\hline $\begin{array}{l}\text { In }(\mathrm{CO} / \mathrm{C}) \\
\text { Time }\end{array}$ & Control & Benzoate & Ethanol & Whey & $\begin{array}{l}\mathrm{Na} \\
\text { Lactate }\end{array}$ & $\begin{array}{l}\text { L. Soil } \\
\text { Lactate }\end{array}$ & Autoclaved & $\begin{array}{l}\text { L. Soil } \\
\text { Control }\end{array}$ \\
\hline 0 & 0 & 0 & 0 & 0 & 0 & 0 & 0 & 0 \\
\hline 2 & 0.43339 & 0.211771 & 0.552717 & 6.210265 & 0.344189 & 6.276017 & 0.219869 & 0.213149 \\
\hline 7 & 1.644553 & 1.108465 & 1.796695 & & 1.685552 & & 0.748284 & 0.379467 \\
\hline 15 & & & & & & & 1.013425 & 0.437214 \\
\hline 24 & & & & & & & 2.1266 & 1.29641 \\
\hline $\mathrm{k}$ & 0.2336 & 0.1544 & 0.2582 & 3.1051 & 0.2356 & 3.138 & 0.0842 & 0.0477 \\
\hline$r^{\wedge} 2$ & 0.9992 & 0.9853 & 0.9992 & 1 & 0.989 & 1 & 0.9636 & 0.8811 \\
\hline t.5 & 2.97 & 4.49 & 2.68 & 0.22 & 2.94 & 0.22 & 8.23 & 14.53 \\
\hline
\end{tabular}

Table B4. RDX Run 2.

\begin{tabular}{|c|c|c|c|c|c|c|c|c|}
\hline RDX & $\begin{array}{l}\text { RDX } \\
\text { Control }\end{array}$ & $\begin{array}{l}\text { RDX Benzoic } \\
\text { Acid }\end{array}$ & $\begin{array}{l}\text { RDX } \\
\text { Ethanol }\end{array}$ & RDX Whey & $\begin{array}{l}\text { RDX Na } \\
\text { Lactate }\end{array}$ & $\begin{array}{l}\text { RDX L. Soil } \\
\text { Lactose }\end{array}$ & $\begin{array}{l}\text { RDX Dead } \\
\text { Control }\end{array}$ & $\begin{array}{l}\text { RDX L. Soil } \\
\text { Control }\end{array}$ \\
\hline 0 & 0.815 & 0.806 & 0.866 & 0.764 & 0.788 & 0.737 & 0.653 & 0.623 \\
\hline 2 & 0.813 & 0.803 & 0.782 & 0.473 & 0.787 & 0.073 & 0.553 & 0.535 \\
\hline 7 & 0.751 & 0.754 & 0.729 & 0.000 & 0.751 & 0.000 & 0.693 & 0.580 \\
\hline 15 & 0.772 & 0.809 & 0.756 & 0.000 & 0.728 & 0.000 & 0.545 & 0.583 \\
\hline 24 & 0.631 & 0.697 & 0.387 & 0.000 & 0.303 & 0.000 & 0.487 & 0.509 \\
\hline & & & & & & & & \\
\hline $\begin{array}{l}\text { In }(\mathrm{CO} / \mathrm{C}) \\
\text { Time }\end{array}$ & Control & Benzoate & Ethanol & Whey & $\begin{array}{l}\mathrm{Na} \\
\text { Lactate }\end{array}$ & $\begin{array}{l}\text { L. Soil } \\
\text { Lactate }\end{array}$ & Autoclaved & $\begin{array}{l}\text { L. Soil } \\
\text { Control }\end{array}$ \\
\hline 0 & 0 & 0 & 0 & 0 & 0 & 0 & 0 & 0 \\
\hline 2 & 0.002457 & 0.003315 & 0.101219 & 0.479741 & 0.000847 & 2.31675 & 0.166127 & 0.152903 \\
\hline 7 & 0.081339 & 0.065836 & 0.172284 & & 0.048113 & & -0.059423 & 0.071518 \\
\hline 15 & 0.053772 & -0.004541 & 0.1359 & & 0.078316 & & 0.18069 & 0.065788 \\
\hline 24 & 0.256411 & 0.145363 & 0.805937 & & 0.956443 & & 0.293139 & 0.202099 \\
\hline $\mathrm{k}$ & 0.0088 & 0.0046 & 0.0267 & 0.2399 & 0.0287 & 1.1584 & 0.0113 & 0.0078 \\
\hline$r^{\wedge} 2$ & 0.8014 & 0.5326 & 0.7581 & 1 & 0.6772 & 1 & 0.5092 & 0.1274 \\
\hline t.5 & 78.77 & 150.68 & 25.96 & 2.89 & 24.15 & 0.60 & 61.34 & 88.87 \\
\hline
\end{tabular}




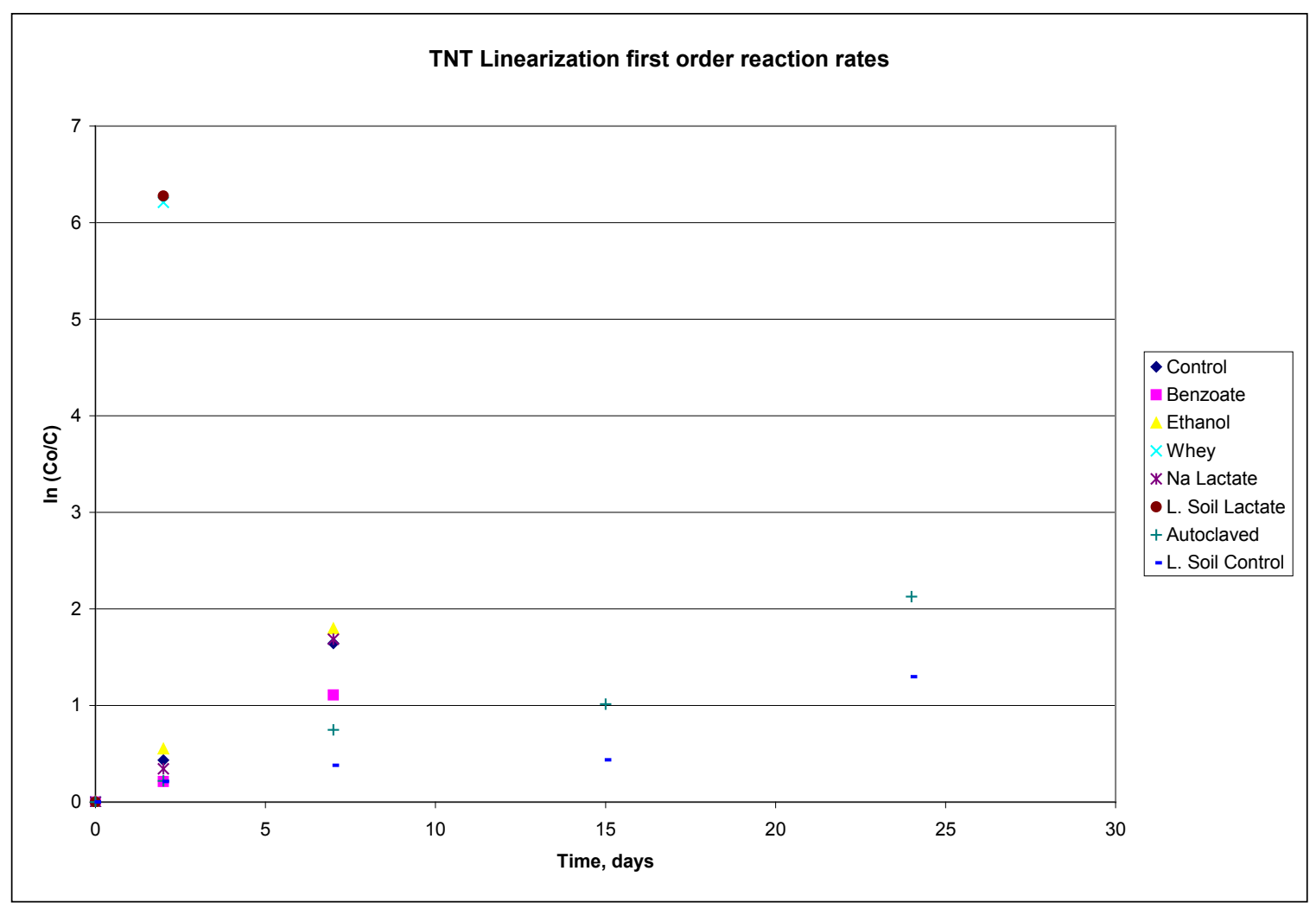

Figure B3. Plot of first-order function linearization TNT Run 2.

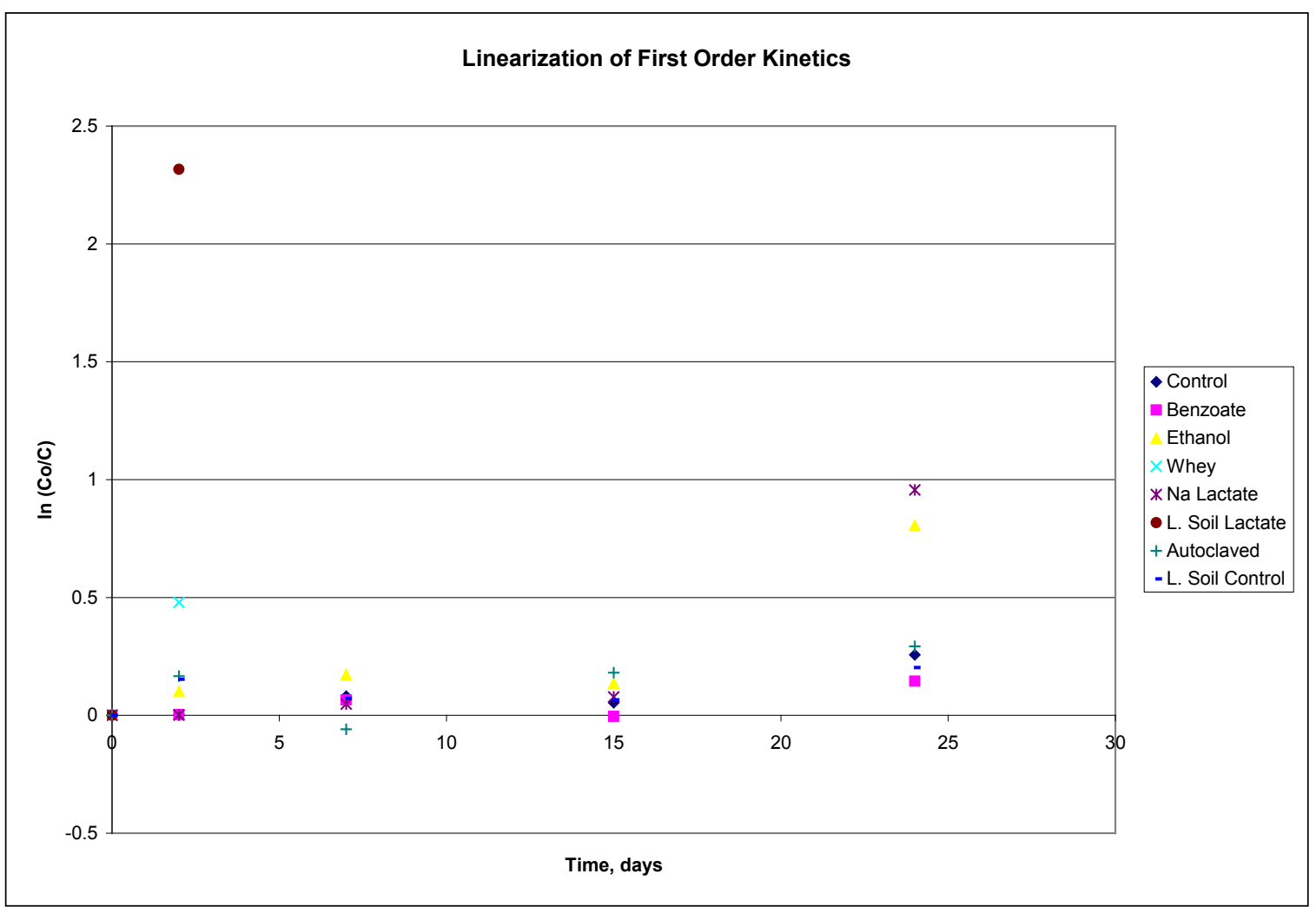

Figure B4. Plot of first-order function linearization RDX Run 2. 


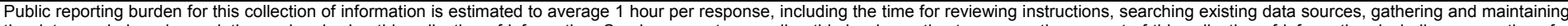

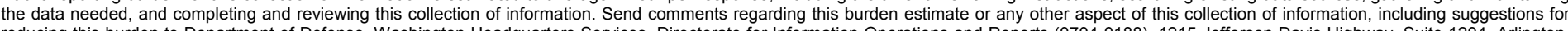

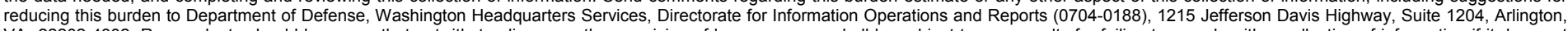

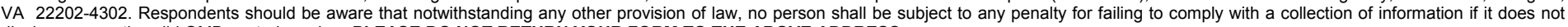
display a currently valid OMB control number. PLEASE DO NOT RETURN YOUR FORM TO THE ABOVE ADDRESS.
1. REPORT DATE (DD-MM-YYYY)
2. REPORT TYPE
3. DATES COVERED (From - To)
Final report

January 2012

\section{TITLE AND SUBTITLE}

The Results of a Laboratory Feasibility Study for the Biological Treatment of Umatilla Groundwater

5a. CONTRACT NUMBER

5b. GRANT NUMBER

5c. PROGRAM ELEMENT NUMBER

\section{AUTHOR(S)}

Victor F. Medina. Heather Knotek-Smith, David Gent, and Agnes Morrow

5d. PROJECT NUMBER

5e. TASK NUMBER

5f. WORK UNIT NUMBER

\section{PERFORMING ORGANIZATION NAME(S) AND ADDRESS(ES)}

U.S. Army Engineer Research and Development Center

Environmental Laboratory

8. PERFORMING ORGANIZATION REPORT NUMBER

3909 Halls Ferry Road

ERDC/EL TR-12-2

Vicksburg, MS 39180-6199

9. SPONSORING / MONITORING AGENCY NAME(S) AND ADDRESS(ES)

10. SPONSOR/MONITOR'S ACRONYM(S)

Headquarters, U.S. Army Corps of Engineers

Washington, DC 20314-1000

\section{SPONSOR/MONITOR'S REPORT} NUMBER(S)

\section{DISTRIBUTION / AVAILABILITY STATEMENT}

Approved for public release; distribution is unlimited

\section{SUPPLEMENTARY NOTES}

\section{ABSTRACT}

The Umatilla Chemical Depot (UMCD) has been slated to close as an Army facility under the Base Realignment and Closure (BRAC) Program. One remaining environmental issue is a groundwater plume contaminated with explosives; the two most critical are 2,4,6trinitrotoluene (TNT) and 1,3,5-trinitrohexahydro-1,3,5-triazine (RDX). Since 1994, a groundwater pump and treat system has operated at the site as a corrective measure for the contaminated groundwater. The effectiveness of this treatment system has plateaued, and it appears that the system will not meet the long-term treatment goals for the site. This study was conducted to evaluate the potential of bioremediation as a means of optimizing the performance of the groundwater treatment system. Groundwater from the site was collected through the groundwater pump and treat. Soil was collected from the wash out lagoon area, which is the primary source area for most of the contamination. These were used to set up microcosm studies to evaluate the biodegradation of the contaminants. Microcosms were set up using 1-liter Erlenmeyer flasks. The groundwater was spiked to about 1.2 and $0.8 \mathrm{mg} / \mathrm{L}$ of TNT and RDX, respectively. The flask had $200 \mathrm{~g}$ of Umatilla soil (some experiments had $50 \mathrm{~g}$ ) and $500 \mathrm{~mL}$ of spiked groundwater. Various treatments were assessed; i.e., various organic amendments were used as co-substrates to stimulate the degradation of TNT and RDX. Nine amendments, as well as various unamended samples, were tested. The reactors were incubated over a 27-day period under an anaerobic hood. Removal of the contaminants was measured, as was the formation and removal of transformation products, changes in $\mathrm{pH}$, Total Organic Carbon, Eh, and dissolved oxygen. TNT was relatively easy to degrade, as it removed even many of the controls. Presumably the anaerobic conditions under the hood were enough to stimulate degradation. RDX, on the other hand, was more difficult to treat. The best amendments were molasses, corn syrup, emulsified oil (EOS), lactose, and whey.

\begin{tabular}{|c|c|c|c|c|c|}
\hline \multirow{5}{*}{\multicolumn{2}{|c|}{$\begin{array}{l}\text { 15. SUBJECT TERMS } \\
\text { Amendments } \\
\text { Base Realignment and Closure Program }\end{array}$}} & & & \multirow{2}{*}{\multicolumn{2}{|c|}{ Groundwater treatment system }} \\
\hline & & Biological treatme & of groundwater & & \\
\hline & & Bioremediation & & \multicolumn{2}{|c|}{ RDX } \\
\hline & & Co-substrates & & \multicolumn{2}{|c|}{ TNT } \\
\hline & & Degradation & & \multicolumn{2}{|c|}{ Umatilla Chemical Depot } \\
\hline \multicolumn{3}{|c|}{ 16. SECURITY CLASSIFICATION OF: } & \multirow[t]{3}{*}{$\begin{array}{l}\text { 17. LIMITATION } \\
\text { OF ABSTRACT }\end{array}$} & \multirow{3}{*}{$\begin{array}{l}\text { 18. NUMBER } \\
\text { OF PAGES } \\
69\end{array}$} & $\begin{array}{l}\text { 19a. NAME OF RESPONSIBLE } \\
\text { PERSON }\end{array}$ \\
\hline a. REPORT & b. ABSTRACT & c. THIS PAGE & & & 19b. TELEPHONE NUMBER (include \\
\hline UNCLASSIFIED & UNCLASSIFIED & UNCLASSIFIED & & & \\
\hline
\end{tabular}

